UNIVERSIDADE DE SÃO PAULO

FACULDADE DE FILOSOFIA, LETRAS E CIÊNCIAS HUMANAS

DEPARTAMENTO DE LETRAS ORIENTAIS

PROGRAMA DE PÓS-GRADUAÇÃO EM LITERATURA E CULTURA RUSSA

\title{
Identidade Nacional Russa na Literatura de Viagem de Dostoiévski e Herzen
}

Lorena Leite Miranda

Dissertação apresentada ao Programa

de Pós-Graduação em Literatura e Cultura Russa da Faculdade de Filosofia, Letras e Ciências Humanas da Universidade de São Paulo, para a obtenção do título de Mestre em Letras.

Orientador: Prof. Dr. Bruno Barretto Gomide

São Paulo

2014 


\title{
Agradecimentos
}

À Universidade de São Paulo.

À FAPESP, financiadora da pesquisa.

\begin{abstract}
A Bruno Barretto Gomide, verdadeira formiga trabalhadora da crescente Eslavística brasileira, responsável por engajar nosso ambiente universitário em constantes diálogos internos e internacionais, além de generosíssimo em partilhar seu conhecimento com alunos e quaisquer interessados nos temas pelos quais apaixonadamente se interessa.
\end{abstract}

Aos amigos que me acompanharam ao longo do labirinto Dostoiévski.

A minha mãe, Eliana Leite, pelo chão dos dias.

A Vitor Cutlak, namorado ao início da pesquisa, noivo durante e hoje marido, companheiro de todas as jornadas. 
O drama da razão exige mais e promete bem menos: afinal, tudo quanto se sabe que ele traz à tona da atenção do ocidental é a luta apaixonante e natural da luz, peripatética e fugaz, para legitimar mais que um sinal do que o ser vai deixando para trás. Um sábio oriental, quando recusa reduzir aos conceitos esse drama, nem por isso o desdenha: há uma confusa tradução por aqui do que se chama de sacro no Oriente: é a mesma chama que arde entre nós na imitação da música.

- Bruno Tolentino 


\title{
Resumo
}

Este trabalho tem por objetivo discutir o pensamento político de Dostoiévski a partir de uma comparação entre Notas de Inverno sobre Impressões de Verão (1863) - ciclo de artigos reunindo as impressões do autor sobre sua primeira viagem à Europa, em 1862 - e outro importante relato de viagem anterior ao de Dostoiévski, Cartas de França e Itália (1855), de Aleksandr Gertsen (Herzen). Estas duas obras, cujos autores ocupam posições bastante distintas dentre o espectro Ocidentalista-Eslavófilo do século XIX russo, contêm em germe as ideias políticas de ambos, sobretudo no que diz respeito à complexa relação Rússia-Ocidente. Entendo que cotejar Dostoiévski com um dos principais representantes de seus adversários ideológicos é um modo profícuo de problematizar, e assim melhor compreender, suas ideias políticas.

Palavras-chave: Fiódor Dostoiévski, Aleksandr Herzen, relato de viagem, intelligentsia russa, século XIX

\begin{abstract}
The dissertation aims at discussing Dostoevsky's political thinking. This shall be done through the comparative analysis of Winter Notes on Summer Impressions (1863) - a collection of articles on the author's impressions after his first trip to Europe, in 1862 - and another important travelogue that preceded Dostoevsky's, Letters from France and Italy (1855), by Aleksandr Gertsen (Herzen). These two works, whose authors take rather divergent positions within the Westernizers-Slavophiles spectrum in $19^{\text {th }}$ century Russia, synthesize their political views, chiefly concerning the complex relationship between Russia and the West. My claim is that comparing Dostoevsky to one of the main spokesmen of his ideological antagonists may prove fruitful to understanding his political ideas.
\end{abstract}

Keywords: Fyodor Dostoevsky, Aleksandr Herzen, travelogue, Russian intelligentsia, $19^{\text {th }}$ century 


\section{ÍNDICE}

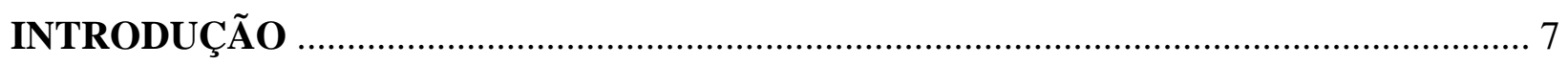

1. Estabelecimento do objeto de pesquisa .............................................................. 7

2. Caminhos da pesquisa. Base teórica, bibliográfica e metodológica .......................... 12

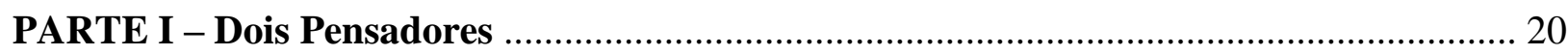

Capítulo 1 - A. I. Herzen: Entre dois mundos .................................................. 20

Capítulo 2 - F. M. Dostoiévski: Cultivar o solo pátrio ............................................. 36

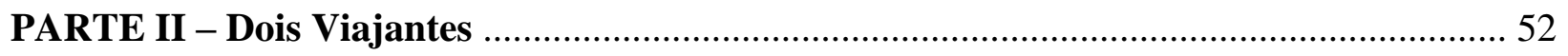

Capítulo 1 - Aspectos gerais dos dois relatos de viagem ....................................... 52

1.1. Cartas de França e Itália .................................................................... 52

1.2. Notas de Inverno Sobre Impressões de Verão ........................................... 60

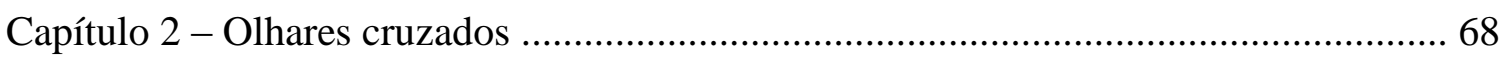

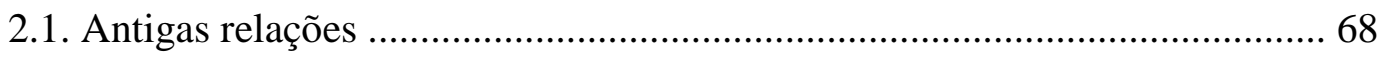

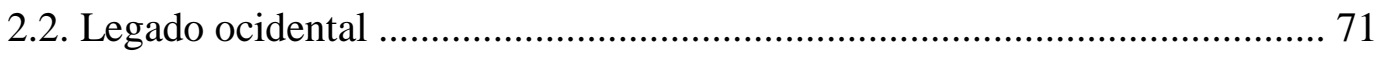

2.2.1. O deplorável burguês ......................................................... 71

2.2.2. Socialismo: escravidão ou liberdade? ..................................... 78

2.2.3. O problema da moralidade: a ética do egoísmo de Herzen .......... 90

2.3. Ascensão da Estrela do Oriente .......................................................... 101

2.3.1. A derradeira metamorfose de Herzen .................................... 101

2.3.2. O Socialismo Russo de Herzen: revolucionário, porque socialista;

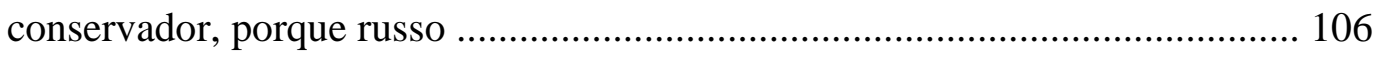

2.3.3. Dostoiévski entre a inspiração e a ideologia ............................ 117 
2.3.4. Um dom dado de graça: a fraternidade naródnik 


\section{INTRODUÇÃO}

\section{Estabelecimento do objeto de pesquisa}

Este trabalho nasceu de meu interesse pelo pensamento político de Dostoiévski, tão central à sua obra quanto eclipsado pelo vigor literário da mesma ${ }^{1}$. Um dos desafios de estudar as ideias políticas de Dostoiévski atualmente está no fato de que, na era pós-Bakhtin, a tendência hegemônica da crítica dostoievskiana continua sendo manter o foco na poética (isto é, no modo de composição das obras do escritor), visando o texto literário como objeto independente das opiniões pessoais e intenções que o autor eventualmente tenha tido ao escrevê-lo. Inclusive, pode-se especular se a notável popularidade de que goza Dostoiévski nos dias atuais não se deve, em grande medida, a essa atitude da crítica, que, ao isolar das obras do escritor sua visão de mundo, cria um campo neutro onde a palavra final é a da livre interpretação. Desse modo, já não é imperativo entender, por exemplo, por que tipo de processo redentor passa Raskólnikov ao fim de Crime e Castigo; o intérprete está livre para, se quiser, enfatizar apenas os aspectos do livro que corroborem, não o que Dostoiévski quis comunicar ao compor sua obra, mas o que o próprio intérprete deseja ou imagina que ela signifique. A relação entre tal atitude da crítica e a popularidade do romancista russo é que ler suas obras como um campo aberto onde virtualmente qualquer leitura é possível, e não como a tentativa literária de determinado indivíduo expressar

\footnotetext{
1 "The neglect of Fyodor Dostoevsky as a political theorist can be explained in part by his choice of imaginative literature rather than discursive argument as his primary mode of communication." WALSH, David, in "Dostoevsky's Discovery of the Christian Foundation of Politics". Religion \& Literature, Vol. 19, No. 2 (Summer, 1987), pp. 49-72.
} 
seus pontos de vista, é um modo muito eficaz de fazer com que um mesmo escritor agrade aos leitores mais ideologicamente contrários, expandindo, assim, a abrangência de seu público.

É fato que a dicção literária de Dostoiévski, diferentemente da maioria dos autores anteriores ao século XX, em diversos momentos dá margem a múltiplas interpretações. Mas será, realmente, que não afirma nada de positivo?

Pode-se dizer que meu interesse por Dostoiévski cresceu à medida que me intrigava a discrepância entre as palavras do autor, que eu lia, e o que se dizia a partir delas ou sobre elas. Daí que, quando enfim decidi tomá-lo como objeto de estudo no Mestrado, estabeleci como corpus de análise o autor-ideólogo, mais do que o artista. É verdade que tal separação só faz sentido abstratamente, para fins pedagógicos; enfatizar o Dostoiévski ideólogo ou filósofo não implica ignorar a dimensão estética que evidentemente faz parte do projeto literário dostoievskiano, significa apenas que busco interpretar Dostoiévski - tanto sua ficção quanto seu jornalismo - desde o ponto de vista do autor. Felizmente, ele nos deixou abundante material por onde buscar reconstituir sua visão de mundo. E felizmente um grande número de estudiosos já se vem debruçando sobre este material há algum tempo, e nem só de livres interpretações vive a crítica dostoievskiana - há também excelentes trabalhos que nos indicam com considerável consistência o caminho das pedras para o mundo do autor.

Tendo estabelecido como corpus de pesquisa o Dostoiévski pensador, o mais natural seria me deter em seus escritos jornalísticos, onde aquilo que seriam suas ideias pessoais vem menos mediado por camadas de ficcionalidade (embora de modo algum se possa tomar qualquer artigo do Dostoiévski jornalista como correspondendo literalmente ao seu pensamento; afinal de contas, estamos lidando com alguém cuja tendência preponderante era escrever ficção) - seria natural, mas excluiria parte muito interessante do fenômeno Dostoiévski, que é justamente o modo como 
sua faceta de ideólogo (aquela à qual se pode e se deve atribuir uma visão de mundo própria) transforma-se na verdadeira encruzilhada literária que tanto fascinou Bakhtin. O Dostoiévski partidário de ideias políticas concretas resiste a sua própria literatura? É mesmo forçoso identificar e compreender, por exemplo, as inúmeras referências ao folclore russo dispersas em sua obra, as quais propagam a mensagem do "cristianismo selvagem" que ele tanto prezava nos camponeses de seu país, ou pode-se simplesmente abraçar a revolta de Ivan Karamázov, ou crer que o crime de Raskólnikov é justificável, e ainda assim estar lendo Dostoiévski?

Para ter a oportunidade de discutir todas essas questões, optei por analisar o pensamento sociopolítico do escritor dentro de uma obra literária (Notas de Inverno Sobre Impressões de Verão, de 1863), sem deixar de recorrer auxiliarmente a seus escritos não ficcionais, para ver de que modo conciliam-se essas duas esferas de sua atividade intelectual. É verdade que as Notas de Inverno, como as Recordações da Casa dos Mortos, são livros híbridos, onde ficção e não-ficção são quase indissociáveis. Suspeitamos da pureza de sua ficcionalidade diante do fato de que o texto foi escrito após o próprio Dostoiévski ter retornado de sua primeira viagem à Europa, em 1862. Ainda assim, há aí, em formato embrionário, algumas características marcantes da literatura madura de Dostoiévski, inaugurada pouco depois com as Memórias do Subsolo (1864).

As Notas de Inverno têm, assim, importância estratégica dentro da obra dostoievskiana, articulando ficção e jornalismo político ao mesmo tempo em que são o marco inicial da obra posterior, pela qual o autor fez sua fama. Contudo, percebi sem demora que estudar este texto significaria necessariamente estudar vários outros autores e obras - a começar pelos viajantes e respectivos relatos de viagem que permeiam a malha do travelogue dostoievskiano. Em seu relato essencialmente crítico em relação às tradições a que se reporta, Dostoiévski responde aos mais diversos ruídos produzidos em torno das principais questões de seu tempo - ideológicas e 
estéticas. As Notas de Inverno são uma verdadeira tessitura intertextual, em que o conhecimento de lugares geográficos se dá por meio de marcos literários que sintetizam características socioculturais dos países que os produziram. E não apenas isso: a apreciação aparentemente despretensiosa e caótica do narrador diante do Velho Mundo é um diálogo consciente com Karamzin, Fonvízin, Custine, Haxthausen e vários outros ilustres viajantes que, sendo russos em visita à Europa ou europeus desbravando a Rússia, ajudaram a compor a tradição do encontro entre esses dois mundos, transmitido em relatos de viagem.

Porém, das tantas referências amalgamadas nas Notas de Inverno, uma me pareceu de peculiar importância, tanto que foi adotada como contraponto norteador da busca por um entendimento das ideias sociais e políticas de Dostoiévski: Aleksandr Herzen, célebre intelectual da geração de Bielínski, socialista e ocidentalista por formação e autor, entre várias outras obras, de Cartas de França e Itália, relato em forma de cartas de sua estadia na Europa durante as revoluções de 1848.

Tomar Herzen como contraponto ideológico que facilite a compreensão da posição política de Dostoiévski é interessante, em primeiro lugar, pelo fato de não haver apenas divergências entre ambos, o que os torna um corpus fiel ao ambiente de debates de sua época. Cotejar Dostoiévski com um Tchernischévski, por exemplo, poderia facilmente gerar a falsa impressão de posições muito bem definidas compondo o cenário intelectual do século XIX russo. Tal cenário, contudo, oferece as maiores dificuldades a toda tentativa de classificação definitiva de seus componentes. Mesmo a divisão entre os dois grandes grupos de Ocidentalistas e Eslavófilos só pode ser aplicada com precisão a um período bastante específico do século XIX russo. O próprio Dostoiévski, com seu inegável pendor ao conservadorismo e olhar utópico sobre a história e caráter russos, não se pode chamar de eslavófilo sem várias ressalvas. Ele jamais 
negou os méritos culturais do Ocidente, tampouco desdenhava da importância de se adquirir formação intelectual a partir de fontes europeias, e (o que o distingue mais nitidamente dos eslavófilos "puros") não deixava de reconhecer certos méritos a partir das intervenções de Pedro, o Grande - embora considerasse que a lição que a Rússia de seu tempo precisava aprender já não era no sentido de desenvolver uma alta cultura, e sim uma lição essencialmente moral.

Herzen, por sua vez, tendo maturado intelectualmente em meio ao tipo mais estrito de ocidentalismo, vai fixar domicílio no estrangeiro para, desde esse ponto de vista distanciado, desenvolver uma visão tão utópica sobre a Rússia quanto a dos mais inflamados eslavófilos. Nas Cartas de França e Itália (cuja composição se inicia logo após o autor deixar a Rússia) ele profetizará o colapso iminente da sociedade europeia de modelo francês. Frustrado com a curta vida e duvidosas consequências revolucionárias dos levantes republicanos iniciados em 1848, Herzen perde as esperanças no socialismo europeu, engajando-se então em um modelo de socialismo tipicamente russo, baseado na comuna camponesa típica de seu país. As semelhanças com Dostoiévski nesse ponto são muitas, como veremos ao longo deste trabalho.

E assim se estabeleceu o eixo da pesquisa: uma análise comparativa dos relatos de viagem de Dostoiévski e Herzen, visando a uma discussão de suas ideias sociopolíticas, as quais são por sua vez um modo de acessar o debate intelectual do século XIX russo, este verdadeiro caldeirão cultural. Dostoiévski continua sendo o centro das atenções, ao passo em que Herzen serve como contraponto para matizar e problematizar as posições do autor das Notas de Inverno. 


\section{Caminhos da pesquisa. Base teórica, bibliográfica e metodológica}

Partindo da percepção de afinidades e divergências entre Herzen e Dostoiévski, estabeleci como tarefa primeira deste trabalho investigar a relação entre as ideias políticas de ambos, tendo como base textual os relatos que cada um escreveu sobre sua experiência ao viajar pela Europa. Esta intenção foi levada a cabo e seu resultado vai exposto nas páginas a seguir. Vale ressaltar, no entanto, que este primeiro objetivo da pesquisa acabou resvalando em alguns problemas consideravelmente mais complexos, cuja magnitude foge ao escopo deste trabalho, mas cujas implicações, uma vez percebidas, já não podem ser desconsideradas.

O turning point em minha compreensão da relação entre as ideias de Dostoiévski e Herzen deu-se a partir da leitura de A Revolução Russa (1931), de Nikolai Berdiáiev (18741948). A visão de Berdiáiev sobre a intelligentsia russa do século XIX pareceu-me aplicar-se perfeitamente aos dois autores aqui em questão, levando-me a crer que uma comparação eficiente entre eles não se esgotaria em apontar suas concordâncias e divergências quanto a temas sociopolíticos, mas deveria também situá-los no plano geral da cultura russa, identificando, quando possível, a origem histórico-cultural de suas ideias comuns. Isto é, não bastaria verificar que Dostoiévski, como Herzen, afirmava um valor intrínseco ao povo russo e esperava que a Rússia tomasse a dianteira política do mundo pós-ocidental; seria preciso entender o que fez com que as mesmas esperanças frutificassem no imaginário de pensadores tão diversos - entender qual é, em suma, sua raiz ideológica comum. Esta seria uma pesquisa posterior ao trabalho aqui apresentado. Mas, como dito anteriormente, tomar consciência da necessidade de tais problematizações fez com que elas estivessem sempre no horizonte - ainda que não no foco central - da comparação que proponho. 
A leitura de Berdiáiev ofereceu, assim, alguns poderosos insights à pesquisa, porém, apenas este autor não seria suficiente para um estudo aprofundado dos problemas que ele próprio aponta, por sua abordagem mais ensaística do que propriamente científica dos mesmos. Deste modo, tive de buscar outras fontes que explorassem mais a fundo as questões levantadas por Berdiáiev em sua análise do caráter da intelligentsia russa - e as encontrei na obra do filósofo político alemão Eric Voegelin (1901-1985). Aquilo que em Berdiáiev são insights sobre a cultura russa, Voegelin integra a uma leitura sistêmica da história das ideias humanas, expandindo consideravelmente o campo de visão do autor russo.

Dada a importância destes dois autores para o curso da pesquisa, convém discutir brevemente algumas de suas reflexões mais diretamente ligadas ao problema da intelligentsia russa no século XIX.

Berdiáiev considera o cisma da Igreja Ortodoxa (raskol) como a experiência seminal da cultura russa:

O raskol é um fenômeno característico e decisivo da história russa, de cuja órbita ainda não escapamos. Os russos são, por sua própria psicologia, inclinados a tornar-se raskólniki (cismáticos). O cisma religioso histórico não se explica somente pelo fato de que uma porção considerável do povo e do clero russos, no período anterior a Pedro I, queria preservar os ritos antigos e a letra da lei em toda a sua pureza. Motivos mais profundos, calcados na história psicológica do povo russo, estavam em ação. Ele [o povo russo] há tempos fora tocado pelo sentimento de uma missão messiânica. Isto ganhara expressão no século XV, nos ensinamentos do monge Filofei sobre a "Terceira Roma” moscovita. Bizâncio tombara e o único Império Ortodoxo restante no mundo, de acordo com Filofei, era o russo; a nação russa, sozinha na terra, era a depositária da fé ortodoxa verdadeira. (...) Quando a 
influência grega manifestou-se na correção de livros litúrgicos e na alteração dos ritos, isto foi considerado como uma traição da parte do poder civil e da hierarquia da Igreja. ${ }^{2}$

Não se tratava, portanto, de mero apego do povo aos ritos estabelecidos, mas do sentimento de que a forma de conduzir a religião não deveria ser imposta aos russos por uma cultura estrangeira, afinal a nação russa era a única depositária do verdadeiro Cristianismo.

Não é difícil perceber que no conflito que culminou no raskol já estão presentes, em forma embrionária, as grandes questões que atormentariam a intelligentsia pós-petrina, relativas ao caráter nacional russo em face de influências estrangeiras. As reformas de Pedro I aprofundaram e como que selaram esse drama, cujo desdobramento, no século XIX, teve muitas vertentes, algumas já totalmente alheias ao conteúdo religioso que caracterizava a revolta original:

O niilismo e a tendência apocalíptica no caráter russo estão conectados, e tal conexão vem à tona nas formas extremas do espírito cismático. A aspiração de ambos pela nudez espiritual, sua recusa dos processos históricos e valores culturais e a expectativa de uma derradeira catástrofe têm raízes fundas na psicologia do raskol, a qual consistia no divórcio entre o povo da Igreja e seus governantes, entre as pessoas comuns e a classe letrada. (...)

[Para os raskólniki], a Rússia Imperial, imersa na civilização europeia, não representa mais o Império Ortodoxo no sentido estrito do termo. Estabelece-se uma atitude de indiferença e desconfiança para com as autoridades. A ideia messiânica religiosa tipicamente russa permanece, mas calcada num profundo divórcio com seus arredores. (...)

Sentimentos apocalípticos, ligados à espera pelo Anticristo ${ }^{3}$, são muito fortes entre as classes populares russas e vêm à tona também em tendências de pensamento religioso entre as

\footnotetext{
${ }^{2}$ BERDYAEV, Nicholas. The Russian Revolution. University of Michigan Press: 1966, p. 2-3.
} 
classes letradas, entre escritores e pensadores russos. Da mesma forma, essas tendências permanecem como forças psicológicas, mas em forma secularizada, em movimentos apartados da consciência religiosa cristã. De modo que se pode verificar uma disposição cismática e escatológica como o fato psicológico principal do século XIX russo; ela vai expressar-se tanto religiosamente quanto de forma anti-religiosa, como numa religião invertida. ${ }^{4}$ (Grifo meu)

A intelligentsia russa oitocentista teria sido, assim, uma classe de cismáticos intelectuais, um raskol intelectual. Sua existência calcava-se na discordância com o presente; ela buscava ora um passado idealizado, identificado com a Rússia anterior a Pedro I, ora um futuro utópico, inspirado em um Ocidente ideal. Ela não considerava os sucessos do Estado Russo como seus próprios sucessos. Todos os intelectuais do século XIX na Rússia, fossem de tendência ocidentalista ou eslavófila, recusavam seu tempo presente como um período no qual a vocação do povo russo não estava sendo cumprida.

A contribuição de Voegelin a esta reflexão de Berdiáiev é oferecer-lhe um plano de fundo histórico detalhado, compreendendo o messianismo russo dentro do quadro geral da mentalidade gnóstico-messiânica que marcou a história intelectual humana desde os primórdios do Cristianismo.

O messianismo cristão original nasceu da espera pela segunda vinda de Cristo e subsequente vitória do Reino dos Céus sobre a miséria terrena. Os primeiros cristãos, entendendo de forma literal as pregações do apóstolo Paulo, acreditavam que a parousia histórica era de fato iminente. Assim, entre os povos marcados pela cultura cristã, a espera angustiante pelo retorno de Cristo foi aos poucos dando origem a movimentos messiânicos com o objetivo de estabelecer

\footnotetext{
${ }^{3} \mathrm{Na}$ escatologia cristã, o reino do Anticristo marca o início do fim dos tempos.

${ }^{4}$ Idem, p. 4-5.
} 
sociedades perfeitas, que a seu modo criassem as condições para o estabelecimento do Reino dos Céus na terra, como que "apressando" a parousia. Conseguintemente, como a tarefa de estabelecer a sociedade perfeitamente cristã só poderia caber a um povo eleito por Deus, consagrou-se a disputa entre as várias "Romas" históricas, das quais Moscou seria a terceira, após as duas primeiras (Roma e Constantinopla) terem tombado. Este movimento da esfera cultural da sociedade russa tinha também um forte significado político:

As datas da ascensão e institucionalização da ideia [da Terceira Roma moscovita] são importantes. O reino de Ivan, o Grande coincide com a consolidação dos Estados nacionais do Ocidente (Inglaterra, França e Espanha), e os reinos de Ivan IV e Teodoro I coincidem com a Reforma. Precisamente na época em que a articulação imperial do Ocidente se desintegrou, quando a sociedade ocidental rearticulou-se em nações e na pluralidade de igrejas, a Rússia iniciou sua carreira de herdeira de Roma. Desde seus primórdios, a Rússia não era uma nação no sentido ocidental, mas uma área civilizacional, dominada etnicamente pelos Grandes Russos e moldada em uma sociedade política por meio do simbolismo da continuação romana. $^{5}$

Ora, uma vez que um conjunto de símbolos, aliado ao sentimento de uma missão histórica, passa a fazer parte da identidade de um povo, ele se desenvolve e se transforma junto com este povo, e assim a ideia da Terceira Roma moscovita, originalmente designando o papel do povo russo na construção do Reino dos Céus na terra, muito naturalmente acabou restringindo-se à missão de estabelecer uma sociedade de justiça e igualdade a todos os homens, de acordo com o credo secular das ideologias materialistas. Como bem notou Berdiáiev, a

\footnotetext{
${ }^{5}$ VOEGELIN, E. "The New Science od Politics". The Collected Works of Eric Voegelin - vol. 5. Columbia e Londres, University of Missouri Press: 2000, p. 182.
} 
tendência original aí permanecia como força psicológica, mas apartada da consciência religiosa cristã. Voegelin também nota esta inversão:

Com Khomiakóv, teve início a filosofia da história eslavófila e anti-ocidental, a qual enfatizava o apocalipse da Terceira Roma, obtendo grande efetividade junto à intelligentsia da nobreza média, propagando a missão messiânica e escatológica da Rússia em relação à humanidade. Em Dostoiévski essa superimposição do messianismo cristalizou-se na visão curiosamente ambivalente de uma Rússia ortodoxa e autocrática que de alguma forma conquistaria o mundo e, através dessa conquista, floresceria na sociedade livre de todos os cristãos unidos pela fé verdadeira. Essa visão ambivalente, em sua forma secular, é que inspira a ditadura do proletariado russa, a qual em sua conquista do mundo florescerá no reino marxiano da liberdade. ${ }^{6}$

Tendo em vista o exposto acima, não será difícil perceber, ao longo deste trabalho, que Dostoiévski e Herzen foram dois grandes expoentes da mentalidade messiânica segundo analisada por Berdiáiev e Voegelin, representando, respectivamente, as tendências religiosa e "religiosa-invertida" do messianismo enquanto fenômeno intelectual e cultural. Espero, com a exposição subsequente, demonstrar os fundamentos desta afirmação. O ideal seria dedicar uma terceira parte deste trabalho à análise dos dois autores à luz dos conceitos empregados por Berdiáiev e Voegelin, de modo a localizar histórica e filosoficamente as semelhanças e divergências apontadas durante a análise dos relatos de viagem. Porém, esta mostrou-se uma tarefa demasiado vasta para cumprir-se dentro do tempo disponível. Ficam aqui estes breves apontamentos apenas para sinalizar este importante norte teórico, cuja presença deverá fazer-se sentir nas próximas páginas.

\footnotetext{
${ }^{6}$ Idem, p. 183.
} 
Cabe ainda listar outros autores e obras de grande importância à elaboração deste trabalho, sendo que a lista completa de obras consultadas encontra-se na Bibliografia, ao final, bem como as referências editoriais das obras seguir.

Para o estudo de Herzen, foram fundamentais o estudo crítico-biográfico de Edward Acton, Alexander Herzen and the Role of the Intellectual Revolutionary; os ensaios de Isaiah Berlin em Pensadores Russos (principalmente "Alexander Herzen" e "Herzen e Bakúnin sobre a liberdade individual"); o estudo de Judith Zimmerman, o qual prefacia sua tradução para o inglês das Cartas de França e Itália; o ensaio introdutório de Isaiah Berlin à tradução inglesa de $O$ Povo Russo e o Socialismo; e o capítulo sobre o relato de viagem de Herzen em Journeys to a Graveyard. Perceptions of Europe in Classical Russian Travel Writing, de Derek Offord.

Quanto a Dostoiévski, as obras cuja presença se faz sentir mais fortemente na forma final da dissertação são as seguintes: os cinco volumes da biografia Dostoiévski, de Joseph Frank; Dostoevsky, Grigor'ev, and Native-Soil Conservatism, de Wayne Dowler - livro fundamental para a compreensão do Pótchviennitchestvo, inclusive por disponibilizar longas citações de artigos publicados nas revistas Vriêmia e Epókha, das quais foram extraídos os trechos analisados ao longo deste trabalho; Dostoevsky, de Nikolai Berdiáiev (em tradução inglesa); Dostoiévski: do duplo à unidade, de René Girard; Political Apocalypse: a study of Dostoevsky's Grand Inquisitor, de Ellis Sandoz; Dostoevsky and the Russian People, de Linda Ivanits; e o capítulo sobre o relato de viagem de Dostoiévski em Journeys to a Graveyard. Perceptions of Europe in Classical Russian Travel Writing, de Derek Offord. 
Feitas todas as considerações bibliográficas, resta dizer que este trabalho ganhou a forma de uma comparação em duas frentes: de um lado, a percepção que os dois autores estudados têm sobre a cultura europeia, dada em seus relatos de viagem; de outro, sua visão utópica sobre a Rússia, construída a partir da afirmação do declínio da civilização ocidental. É possível afirmar desde já que eles entendem "declínio" de modos diferentes, e por isso proporão distintas “soluções” ao problema. É, contudo, uma dessemelhança sutil, o que não é dizer que seja pouca, mas que é uma dessemelhança tão profunda que, vista de longe, pode passar-se por semelhança.

Por fim, frise-se que o foco da pesquisa, desde o início, foi o pensamento político dos dois autores, tendo como ponto de partida o interesse pelo Dostoiévski ideólogo. Por esse motivo, questões técnicas sobre o relato de viagem enquanto gênero literário não ocupam o primeiro plano da discussão, embora ocorram, evidentemente, quando da comparação das duas obras que são o corpus de análise principal. Advirto ainda que, quando necessário, fomentei a interpretação dos relatos de viagem recorrendo ao restante da obra dos autores. Em certos momentos, os relatos fornecem o ponto de partida para se discutir determinado problema, porém, por serem textos concisos (o de Dostoiévski sobretudo), faz-se necessário buscar este mesmo problema em outros textos para proceder à análise. 


\section{PARTE I - Dois pensadores}

\section{Capítulo 1 - A. I. Herzen: Entre Dois Mundos}

Sem dúvida, Aleksandr Herzen é uma das figuras mais interessantes da intelligentsia russa pré-soviética, não apenas pela qualidade de sua contribuição às letras de seu país, mas porque personifica de forma muito significativa alguns dos dilemas e contradições mais marcantes do período em que viveu. Nascido em 1812, ano da Guerra Patriótica da Rússia contra a França, e falecido em 1870, ele foi um dos agentes determinantes do curso das ideias revolucionárias russas. Sua atividade intelectual foi um dos principais combustíveis de que se nutriu a situação cultural que preparou a Rússia para o "salto" socialista do século seguinte; compreender seu pensamento é, portanto, parte integrante da tentativa de rastrear as origens teóricas desse que é possivelmente o principal acontecimento político do século XX.

Não se trata, porém, de uma análise simples. Herzen localiza-se em uma dessas zonas cinzentas típicas de sociedades em crise, numa das várias encruzilhadas ideológicas nas quais os intelligenty russos com frequência encontravam-se. Prova disso é que não tardou para que gerações posteriores travassem uma encarniçada disputa pelo privilégio de tê-lo a favor de suas respectivas causas - sendo essa uma primeira semelhança sua com Dostoiévski.

A começar pelo próprio Lênin, ainda em 1912:

Cem anos se passaram desde o nascimento de Herzen. Toda a Rússia liberal lhe está prestando homenagens, cuidadosamente evitando as questões sérias do socialismo e tratando de esconder aquilo que distinguia o revolucionário Herzen de um liberal. Também a imprensa 
conservadora comemora seu aniversário, afirmando mentirosamente que em seus anos finais Herzen renunciou à ideia de revolução. E, no estrangeiro, a fraseologia reina suprema nos discursos liberais e naródnik sobre ele. O partido da classe trabalhadora deve comemorar o aniversário de Herzen não por glorificação filisteia, mas com o propósito de esclarecer suas próprias tarefas e assegurar o verdadeiro lugar ocupado na história por este escritor que teve um papel tão importante na abertura do caminho para a Revolução Russa. ${ }^{7}$

Do outro lado da disputa, como exemplo de homenagem liberal prestada a Herzen ainda que mais próxima dos nossos dias do que de Lênin -, veja-se a fala indignada de Isaiah Berlin em seu prefácio a Da Outra Margem:

Por causa de uma ou duas referências elogiosas feitas a ele por Lênin, Herzen, este inimigo da autoridade, que era, talvez, o mais devastador, como certamente era o mais inteligente entre os opositores dos vários comunismos de sua época - o inimigo de todos os dogmas, que declarava que salus populi é um grito tão vicioso quanto lèse majesté, e que nenhum ideal ao qual não se possa sorrir vale a pena - é uma grande ironia que Herzen, que detestava Marx e os 'Marxids' (como os chamava) tanto pessoal quanto politicamente, sendo também duramente criticado por eles, que de todos os homens este mesmo Herzen deva agora encontrar-se canonizado em seu país de origem como um dos fundadores sacrossantos do novo modo de vida. ${ }^{8}$

O curioso é que ambos, Lênin e Berlin, estão parcialmente certos: Herzen de fato manteve esperanças e simpatias revolucionárias até o fim de sua vida, e de fato escreveu

\footnotetext{
${ }^{7}$ V. I. Lênin, Selected Works. Vol. I. 1946, pp. 633-38. Incluído como ensaio introdutório em A. I. Herzen, Selected Philosophical Works. Foreign Languages Publishing House, Moscou: 1956, p. 5-12. A Revolução Russa a que Lênin se refere é a revolução de 1905.

${ }^{8}$ Prefácio à edição em língua inglesa de From the Other Shore \& The Russian People and Socialism. Oxford UP: 1979, p. XX-XXI.
} 
incansavelmente contra regimes políticos que atentam contra as liberdades individuais de seus cidadãos. Em outro momento de seu texto, Lênin denuncia a porção da imprensa russa que "exalta os pontos fracos de Herzen e se cala sobre os fortes."9 Ocorre que, para um autor como Berlin, é Lênin quem enfatiza os pontos errados do pensamento de Herzen, distorcendo-o. E esse jogo de acusações pode continuar ad infinitum, pois há tantos trechos contraditórios entre si na obra de Herzen quanto há grupos ideológicos rivais tentando dar-lhe uma interpretação acabada.

Não quero com isso dar a entender que a obra de Herzen não seja passível de uma leitura que a observe de cima e tente descrevê-la em função do contexto histórico dentro do qual ela faz sentido: este é precisamente um dos objetivos do presente trabalho. Porém, a interpretação que proponho aqui tem por objeto de análise a própria contradição interior do pensamento de Herzen, a ser tomada como sintoma da época - tanto do século XIX russo quanto do que estava por vir.

Dizendo em outras palavras, é preciso encontrar o nexo entre Herzen e Lênin, perfeitamente aceito por este e negado por Isaiah Berlin. E é o próprio Lênin quem nos dá o caminho das pedras:

Ao celebrar Herzen nós vemos claramente as três gerações, as três classes que tiveram parte ativa na Revolução Russa. Primeiro, os nobres e senhores de terra, os dezembristas e Herzen. O círculo destes revolucionários era restrito. Eles estavam muito afastados do povo. Mas seu trabalho não foi em vão. Os dezembristas acordaram Herzen. Herzen semeou a agitação revolucionária. Essa agitação foi estendida, reforçada, trazida ao chão pelos revolucionários de origem popular, começando por Tchernischévski e terminando com os heróis da "Naródnaia Vólia". O círculo de combatentes se expandiu, eles passaram a ter mais contato com o povo. "Os jovens timoneiros da tempestade iminente", Herzen escreveu sobre eles. O proletariado, a única classe revolucionária até o fim, ascendeu à cabeça

\footnotetext{
${ }^{9}$ Lênin, Op. Cit., p. 11.
} 
das massas e pela primeira vez despertou milhões de camponeses ao confronto revolucionário aberto. A primeira arremetida dessa tempestade ocorreu em 1905. A próxima está começando a desenvolver-se diante de nossos olhos. ${ }^{10}$

Apesar dos esforços retóricos de Isaiah Berlin, é necessária uma boa dose de wishful thinking para ignorar o papel fundamental de Herzen enquanto catalisador da situação revolucionária na Rússia e afirmar que entre ele e os bolcheviques há contradição e não complementariedade. A comparação com Dostoiévski nos ajudará a entender que uma revolução como a de 1917 começa em níveis muito mais profundos do que o da agitação subversiva e da chamada às ruas. Herzen também contribuiu nesse sentido, mas sua função no processo revolucionário russo foi sobretudo a de desconstrutor moral: ele personifica a transição - e daí as tantas contradições internas em seu pensamento - entre a velha ordem burguesa, com suas instituições e valores típicos, e a nova realidade revolucionária, que no sistema soviético mostrar-se-ia avessa a tudo o que outrora sustentara o mundo burguês, do ponto de vista comportamental e moral. O drama de Herzen foi perceber que, para levar até o fim seu ideal sócio-político, boa parte do mundo ao seu redor teria de ser destruído - inclusive, eventualmente, ele mesmo enquanto indivíduo. Isto ficará abundantemente ilustrado mais adiante, a partir do comentário sobre seu desencanto europeu entre os anos de 1848 e 1852.

Como exemplo da qualidade adaptativa dos discursos de Herzen, ou da coexistência de pontos de vista contraditórios em sua análise de uma mesma situação, comparem-se os dois grupos de cartas escritos por ele já no fim da vida, na década de 60: Cartas a um Adversário (1865), endereçadas a Iúri Samárin, seu velho amigo dos anos 40, notabilizado mais tarde por

\footnotetext{
${ }^{10}$ Idem.
} 
esposar pontos de vista eslavófilos; e Cartas a um Velho Companheiro (1869), endereçadas ao anarquista Mikhail Bakúnin.

Quando se dirige ao reacionário Samárin, Herzen advoga abertamente pelos arroubos revolucionários da juventude e por seus impulsos destrutivos ainda que desorganizados, pois vê nisso sinal de que as trevas da impassibilidade política estão se dissipando:

Temo que seremos nós, os velhos, e não a nova geração, que enfim nos repreenderemos por termos hábitos não naturais. Você e eu, em nosso tempo, impelidos pela necessidade, éramos sonhadores, filósofos, teóricos, ratos de bibliotecas, esposas secretas de nossos ideais. Os novos produtores que subiram ao palco o qual, aos poucos, tinha sido abandonado pela velha geração guiaram a juventude em uma direção diferente, e se educaram os jovens menos a partir de livros, ensinaram-nos mais por meio de exemplos. (...)

Os momentos em que um país inteiro começa a revolver-se em seu sono são magníficos! A aurora ilumina os vértices de todas as classes da sociedade e todos sentem que uma nova era, um novo dia, está a caminho. E você ainda consegue conceber que um povo jovem, que garotos de dezesseis ou dezessete anos ficariam parados e sobriamente continuariam seus estudos com aquela mesma impassibilidade forçada e aquela diligência desesperada que nós tínhamos quando frequentávamos a universidade? Por que você vê nessa explosão natural de entusiasmo jovem nada além de desordem e ataque ao sistema (e que sistema!)? Que direito nós temos de apedrejar esses jovens por serem imprudentes e não estudarem a fundo seus manuais escolares? ${ }^{11}$

Quando, porém, seu interlocutor é Bakúnin, o discurso de Herzen muda drasticamente. Bakúnin, para quem a destruição constituía uma força construtiva, era, nas palavras de Isaiah Berlin, alguém "moralmente despreocupado e intelectualmente irresponsável, um homem que,

\footnotetext{
${ }^{11}$ Idem, "Letters to an Opponent", p. 558.
} 
em seu amor abstrato pela humanidade, estava disposto, como Robespierre, a derramar rios de sangue." ${ }^{12}$ Diante do extremo representado por seu amigo desordeiro, Herzen assume um tom sóbrio e grave e, nas entrelinhas, censura em Bakúnin a falta de estudo e ponderação teórica que em Samárin lhe pareciam excessivos:

Não tenho horror à expressão "progresso gradual", por mais que a descreditem as vacilações e erros de diversos reformadores. O "progresso gradual”, como a continuidade, é uma parte inalienável de todo processo de compreensão. A matemática é transmitida gradualmente; por que, então, assumir que o homem possa ser inoculado com deduções finais e que as ideias da sociologia possam ser aplicadas como uma vacina contra varíola? (...)

Toda tentativa impaciente de pular um estágio, de seguir adiante à força de paixões ou de exemplos pessoais, levará a conflitos horrendos e, o que é pior, à derrota quase certa. É quase tão impossível escapar do processo de compreensão quanto o é evitar a questão da força. Tomar de surpresa um homem que está mentalmente sonolento e atordoá-lo antes que esteja inteiramente desperto com ideias que vão contra todas as suas concepções morais e para as quais ele não foi gradualmente preparado não contribuirá para o seu desenvolvimento, mas antes o desorientará. (...) Nossos dias são precisamente os dias de estudo meticuloso que devem preceder o trabalho de realização, assim como a teoria do vapor precedeu a construção de estradas de ferro. (...) Não acredito que pessoas que preferem a destruição e a força bruta à evolução e a acordos amigáveis sejam realmente sérias. ${ }^{13}$

Frise-se que esses dois textos não foram escritos em fases distintas do desenvolvimento intelectual de Herzen, mas praticamente na mesma época. O que os diferencia é mesmo o público alvo de cada um. Não é de se estranhar, portanto, que antagonistas ideológicos como

\footnotetext{
${ }^{12}$ BERLIN, Isaiah. Russian Thinkers. “Herzen and Bakunin on Individual Liberty”. Penguin Books: 1994, p. 113.

${ }^{13}$ A. I. Herzen, "Letters to an Old Comrade". Selected Philosophical Works. Foreign Languages Publishing House, Moscou: 1956, p. 584.
} 
Lênin e Berlin busquem - e consigam consistentemente - enfatizar a face da moeda herzeniana mais afim a suas respectivas ideias. Mas, novamente, não quero dar a entender que Herzen seja um mero "duas caras". O que ocorre é que sua relação com a ideia de uma drástica revolução política e social era ambígua, desconfiada, hesitante. De modo geral, Herzen era sempre o maior dos entusiastas às vésperas de qualquer manifestação revolucionária e seu ferrenho crítico no dia seguinte. O que é o mesmo que dizer que ele nunca conseguiu lidar bem com as consequências práticas de suas ideias teóricas. Se tivesse vivido para ver a Rússia pós-1917, provavelmente teria, como Isaiah Berlin, erguido o punho contra o ataque soviético à soberania individual, declarando que suas ideias nada tinham em comum com tal desenvolvimento do processo político russo:

Os caminhos humanos são longos e tortuosos; os da violência, curtos e retos. Recorrer a eles demanda um coração de pedra, uma mente estreita e um poder absolutamente ilimitado; também demanda executores que nunca perguntem por que nem para quê. Possuir tudo isso, mais incompetência e mediocridade, e em circunstâncias favoráveis, leva a altos níveis de absurdidade e arruína sabe Deus o quê: "Que Petersburgo ressurja dos charcos", transformem-se vilas em acampamentos militares e acampamentos militares em vilas. (...)

Não importa sob qual necessidade lógica ou natural nós nos encontremos, não devemos renunciar à nossa vontade moral livre, a nossa sagrada e soberana independência, para a qual nunca tomaremos como critério algo fora de nossa consciência. É por isso que entendemos tão bem a voz do jovem homem que hesita em derramar sangue e pergunta-se: “Alguém deveria realmente ser um instrumento cego do governo?"14

\footnotetext{
${ }^{14}$ Idem. "Letters to an Opponent", p. 567-570.
} 
Ainda assim, malgrado a nobreza e a correção de tais palavras, Lênin continuaria a ter razão em elencar Herzen como avô dos bolcheviques.

A interpretação do papel de Herzen no quadro da história política e cultural da Rússia, a ser feita ao longo deste trabalho, é de matriz dostoievskiana. Veremos como Dostoiévski ergueu seu esboço de uma teoria política sobre uma complexa ética fundada na organicidade entre o indivíduo e seu meio ambiente imediato, nacional, como método para cada nação (e cada indivíduo) cumprir o papel que lhe foi designado no plano da Providência. A Revolução Russa, para Dostoiévski, começou quando o primeiro de seus conterrâneos decidiu que poderia viver fora da lei divina e construir o melhor dos mundos aqui mesmo na terra, sem esperar pelo reino dos céus. Simbolicamente, podemos ver em Herzen esse primeiro homem - apenas simbolicamente, de vez que ele já é um expoente tardio e culminante do mencionado processo de imanentização da consciência humana.

Por todo o exposto acima, fica claro que compreender Herzen exige mais do que categorias historiográficas como esquerda x direita, Ocidentalismo x Eslavofilismo - é preciso buscar o homem por trás do polemista, o indivíduo no qual se sustenta certo conjunto de ideias político-filosóficas, ainda mais porque um dos traços preponderantes de seu pensamento é o foco na realidade imediata, no mais particular aqui-e-agora.

Entre os principais estudiosos da obra de Herzen, um que levou às últimas consequências esse preceito foi Edward Acton, em seu Alexander Herzen and the Role of the Intellectual Revolutionary (Cambridge UP: 1979), no qual o crítico analisa o pensamento de Herzen à luz 
dos principais eventos que marcaram sua trajetória biográfica (de modo semelhante ao que fez Joseph Frank com Dostoiévski). Acton conta a história do relacionamento de Herzen com o processo revolucionário de seu tempo, tendo como eixo a busca incessante do escritor por um papel ou função (role) que lhe coubesse, enquanto indivíduo, dentro do panorama do movimento revolucionário russo e, até certo momento, europeu ${ }^{15}$. E mostra como, ao longo de toda a sua vida, Herzen foi movido pelo desejo de viver uma "existência completa", onde uma personalidade desenvolvida plenamente atualizar-se-ia em um papel histórico bem demarcado, consumando a importância, a singularidade, a imprescindibilidade do indivíduo Aleksandr Herzen. Isaiah Berlin refere-se a essa mesma característica: "ele desejava o mais rico desenvolvimento possível do caráter pessoal, valorizava a espontaneidade, a franqueza, a distinção, o orgulho, a paixão, a sinceridade, o estilo e a cor dos indivíduos livres." ${ }^{16}$ Trata-se de uma visão de mundo com fortes traços românticos, o que apenas confirma o fato de que Herzen foi um homem dos anos 40 - aliás, não há entre os grandes intelectuais russos quem mais se assemelhe a Pável Kirsánov, o liberal aristocrático de Pais e Filhos, de Turguêniev.

Herzen personificava a fusão tipicamente oitocentista entre uma origem social nobre, uma educação refinada e cosmopolita e uma devoção fervorosa às ideias revolucionárias que, levadas às suas consequências lógicas finais, demandavam a destruição da cultura e dos alicerces tradicionais do Ocidente (isto é, da forma mentis do próprio revolucionário em questão) em nome de uma reconstrução total da sociedade. Herzen, como já pudemos verificar, teve uma relação complexa com essas ideias, às vezes abraçando-as até às últimas consequências, às vezes rejeitando-as justamente por horror ao seu potencial para a destruição. Tudo isto aponta para o fato de que estamos diante de um autor em luta consigo mesmo, cujo drama consistiu em que

\footnotetext{
${ }^{15}$ Veremos adiante que, a partir de certo ponto, Herzen desiste de interferir diretamente nas questões europeias e passa a identificar-se exclusivamente com o desenvolvimento da esquerda russa.

${ }^{16}$ BERLIN, Isaiah. "Herzen and Bakunin on individual liberty". Russian Thinkers. Penguin Books: 1994, p. 87.
} 
alguns de seus ideais mais caros significaram, em certos momentos de sua vida, sua mais profunda miséria pessoal.

Isaiah Berlin comenta sobre a geração de intelligenty dos anos 40:

Esses jovens têm um lugar próprio na história da cultura europeia no século dezenove. Eles pertenciam à classe daqueles que são aristocratas por nascimento, mas que, por espontânea vontade, tomam um curso de pensamento e de ação mais livre e mais radical. (...) Suas mentes vêem horizontes largos e generosos e, acima de tudo, revelam uma vivacidade intelectual do tipo que uma educação aristocrática tende a produzir. Ao mesmo tempo, eles estão intelectualmente do lado de tudo que é novo, progressivo, rebelde, jovem, daquilo que está prestes a se tornar realidade, do mar aberto, haja ou não terra firme do outro lado. $^{17}$

A alcunha de "homens supérfluos", atribuída às gerações que precederam a radicalização das ideias revolucionárias em meados do século XIX, remete à atividade mormente teórica ou intelectual desses pensadores, para quem entender e discutir os problemas da sociedade em que viviam era a principal preocupação, em detrimento de práticas subversivas com fim em si mesmas, como pregariam os "homens de ação" dos anos 60. Mas o que se deve ter em mente é que, no caso dos homens dos anos 40, eles não exatamente "optaram" por habitar o mundo das ideias; vivendo sob a vigilância cerrada do tsar Nicolau I, essa geração de intelligenty teve de adaptar seu papel a circunstâncias de extrema censura. Herzen, porém, tinha grandes sonhos para si mesmo e para o lugar que ocuparia no quadro da revolução social, na qual ele acreditava cegamente. Segundo Acton:

${ }^{17}$ BERLIN, Isaiah. “Alexander Herzen”. Russian Thinkers. Penguin Books: 1994, p. 187. 
A experiência pessoal de Herzen sob Nicolau moldou as três principais características de sua atitude nos anos 40. Em primeiro lugar, ele via a reconciliação entre o indivíduo e a comunidade como o mais urgente problema impondo-se à sociedade e aos pensadores. O indivíduo livre e uma sociedade justa e coesa eram seus ideais supremos. E sua concepção do homem como inerentemente social e político, sua visão de que satisfazer a vida privada implica envolvimento nos "interesses gerais", não apenas remove qualquer contradição fundamental entre ambos [indivíduo e sociedade], mas os torna complementares. O segundo ponto é que sua atitude era imbuída de otimismo. Ele aguardava com confiança a "reforma futura" que resolveria o problema. Finalmente, a vida individual rica e equilibrada não seria apenas o produto final dessa regeneração socialista: ele a desejava para si. Mesmo que a dimensão política de sua vida tivesse que ser vivida trabalhando para a utopia e não desfrutando dela, mesmo que a injustiça social e a opressão do indivíduo continuassem, ele queria a vida completa para si, agora. ${ }^{18}$

Por um lado, durante o reinado de Nicolau I a elite civilizada criada pelas reformas petrinas já atingira a maturidade, desejando intensamente expressar-se e fazer pleno uso dos recursos proporcionados pela ocidentalização, mas, por outro, com a imprensa e o ambiente cultural estritamente censurados, os intelligenty eram forçados a calar-se, ou a restringir sua atuação a debates privados entre amigos. A origem da profunda revolta de Herzen contra a opressão do indivíduo, sua principal batalha ao longo de toda a sua vida, parece remeter-se à sua experiência nessa época. Tão mais porque o governo tsarista o submeteu a dois períodos de exílio, na década de 30, sob acusação de ter "ideias perigosas", alheando-o da sociedade moscovita para forçá-lo a ocupar cargos públicos em províncias do interior. E para um homem com a firme intenção de participar dos "interesses gerais" e de ter uma vida plena de sentido

\footnotetext{
${ }^{18}$ In: ACTON (1979), p. 7-8.
} 
nada poderia ser pior do que ver-se preso a uma rotina de serviço burocrático junto ao Estado que ele tanto detestava.

Assim, porque impedidos de expressar publicamente suas ideias (pois mesmo falas privadas poderiam ter consequências desastrosas), restava aos "homens supérfluos" dos anos 40 reunir-se "em círculos sociais privados, onde engajavam-se em intensas amizades baseadas tanto em afinidades ideológicas quanto em compatibilidade pessoal." ${ }^{19}$ Herzen, após dois períodos de exílio (em Viatka e em Vladímir, depois em Novgorod), retorna a Moscou em 1842, onde passa a ser o centro de um novo círculo de comparsas intelectuais, ao lado de seu amigo mais próximo, Nikolai Ogarióv. Aqui, estamos diante de ocidentalistas “clássicos":

Fortemente influenciados por Hegel, [eles] percebiam um único grande sistema de desenvolvimento histórico, no qual a Europa Ocidental manifestava o padrão que a Rússia, por fim, seguiria. Eles portanto negavam a seu país um papel especial e providencial na História, e aplaudiam esforços para que a Rússia se alinhasse cada vez mais ao Ocidente. Eles admiravam a Europa Ocidental por sua tecnologia, sua prosperidade, seus sistemas políticos e de modo geral pelo dinamismo de sua cultura - em contraste com a suposta imobilidade da Rússia tradicional. ${ }^{20}$

Herzen, porém, sempre esteve mais próximo do socialismo francês - de Louis Blanc, George Sand, Proudhon, entre outros - do que do idealismo alemão, embora sem dúvida fosse, como toda a sua geração, um leitor voraz de Hegel. Seus ensaios "Diletantismo na Ciência" (1842-3) e "Cartas Sobre o Estudo da Natureza" (1845) são, nas palavras de Acton, “a mais

\footnotetext{
${ }^{19}$ ZIMMERMAN, Judith. "Translator's Introduction". Letters From France and Italy. University of Pittsburgh Press: 1995, p. XII.

${ }^{20}$ Idem, p. XIII.
} 
importante crítica feita a Hegel pela esquerda russa." ${ }^{21}$ Com efeito, antes de partir para a Europa, em 1847, ele romperia com seus comparsas moscovitas em grande medida por rejeitar o idealismo que tinha como corolário o sacrifício do indivíduo e do momento presente em nome de uma utopia futura, e que partia do pressuposto determinista de que a história segue um plano e uma ordem inevitáveis.

Mas como conciliar o otimismo político de Herzen, que o acompanhou até o fim da vida, com sua crítica ao determinismo idealista? Acton propõe uma solução eloquente:

Herzen questionava as implicações panteístas da filosofia de Hegel. Em vez de agonizar no embate entre materialismo e idealismo, ele rejeitava um Absoluto que dominasse o desenvolvimento humano, pois sua afirmação primordial era a favor do indivíduo. (...) Ele alertava contra a confiança num futuro que nunca se realizará alinhado com nosso pensamento. Este ceticismo impediu que Herzen internalizasse uma filosofia da história racionalmente construída, a qual considerava que uma ideia tinha de realizar-se inevitavelmente - e em 1847 ele rejeitara o sistema de Hegel. Mas seu otimismo estava intacto. Sua fonte era mais profunda do que qualquer justificativa lógica derivada da filosofia ocidental - ele fundamentava-se primariamente na conjuntura da personalidade de Herzen e da realidade russa. Somente golpes políticos e pessoais poderiam subjugar o que era essencialmente uma suposição emocional. ${ }^{22}$

A leitura de Acton é eloquente porque, fosse o otimismo político de Herzen de base hegeliana, ou inspirado em qualquer outro discurso filosófico ocidental, não teria sobrevivido à frustração generalizada que o escritor experimentou em seu exílio europeu entre o fím da década

\footnotetext{
${ }^{21}$ ACTON, Op. Cit., p. 10.

${ }^{22}$ Idem, p. 10-11.
} 
de 40 e os primeiros anos de 1850. Pelo contrário, veremos que sua fase de maior idealismo começou a partir de seu desencanto ocidental.

Mas por ora assinalemos apenas que, à altura de 1846, as reuniões com seu círculo de amigos moscovitas evidenciavam cada vez mais a incompatibilidade entre Herzen, apologeta de um individualismo irrestrito, e os hegelianos que o cercavam, imbuídos de um fervor altruísta que beirava a religiosidade. Para Herzen, nesse momento, a revolução de que a humanidade mais necessitava era a revolução interior, de cunho moral, que a livraria dos grilhões dos "ídolos" aos quais entregava sua independência em troca de segurança psicológica. Ele afirmava que um homem de mente sã e com respeito por si mesmo deduz por conta própria as leis morais de que precisa e não se sacrifica em nome de algum brumoso futuro. "As pessoas não entendem", diz ele, "que se um homem, desprezando a si mesmo, respeitar qualquer outra coisa, ele certamente se reduz a pó diante do objeto, torna-se seu escravo."23

Mas o ambiente intelectual na Rússia dos anos 40 era permeado pela noção da missão histórica dos intelligenty, destinados a construir um futuro para seu triste país e sucumbir, se necessário, sob o peso de tal responsabilidade. Isto não ecoava em Herzen: nem vida após a morte, nem distante futuro de justiça social - sua vida e sua personalidade completas haviam de vingar imediatamente. E foi assim que a ideia de uma viagem à Europa começou a tomar forma: seu país e seu círculo social imediato não ofereciam boas expectativas, não sanavam sua fome de viver. Contava também o fato de que ele, entre seus amigos, era o único que jamais saíra da Rússia. E, para completar, a atmosfera político-cultural da Europa era então verdadeiramente promissora. "O ocidente, e sobretudo a França, era o berço da revolução; fora lá que passos

${ }^{23}$ Sobrânie sotchiniêni v trídtsati tomákh. Moscou: Izdatel'stvo Akademii nauk SSSR, 1954-1965. Tomo II, p. 93. Cf. seção 2.2.3, abaixo. 
concretos tinham sido dados no passado, e era a França que oferecia as maiores esperanças de uma continuação em direção ao socialismo."24

Herzen deixa a Rússia em 1847, acompanhado de sua esposa Natalie, dos três filhos pequenos do casal e de todo um séquito de parentes e empregados, para embarcar num autoexílio que, inicialmente temporário, resultaria no adeus definitivo da família ao solo russo. Herzen partira movido pelo desejo de ver o "olho do furacão" e estar onde o futuro estava. Mas, em verdade, sua viagem à Europa marcará o início do período mais negativamente turbulento da vida do escritor: à agonia política de 1848 se somará sua derrocada na esfera pessoal, tanto em sua busca por um papel ativo nos acontecimentos do momento quanto no próprio seio de sua família. E, como veremos, o primeiro a unificar todas essas experiências sob o fato de seu desencanto pela sociedade ocidental será o próprio Herzen.

O ocidentalista russo expatriado voltar-se-á, então, à sua pátria mãe, concentrando nela, mesmo à distância, suas esperanças políticas e construindo para ela um modelo de socialismo teórico sob medida - o Socialismo Russo. A jornada europeia de Herzen fará dele, em suma, uma síntese viva das contradições culturais de seu país, processo que ele mesmo resume em uma das cartas a Iúri Samárin:

Quando, em Moscou, eu disputava com os eslavófilos (entre os anos 1842-1846), minha visão de mundo era fundamentalmente a mesma [de hoje]. Mas então eu não conhecia o Ocidente, isto é, tinha dele um conhecimento livresco, teórico, e o amava porque odiava o despotismo de Nicolau e o regime de Petersburgo. Quando vi com quanta coragem a França levantava a questão social, presumi que ela a resolveria, ao menos em parte, e era esse o motivo por que então eu era considerado um ocidentalista. Um ano de Paris me fez mais

${ }^{24}$ ACTON, Op. Cit., p. 14. 
sóbrio, pois foi o ano de 1848. E comecei a atacar o Ocidente em nome daqueles mesmos princípios que tinham fundamentado minha querela com os eslavófilos.

Quando declarei abertamente o que pensava sobre a revolução [de1848], isto não significava que eu tomaria o lado de seus inimigos; a queda da República de Fevereiro não me jogaria nos braços nem do catolicismo nem do conservadorismo: mas ela me levou de volta para casa. Achando-me no campo dos derrotados, chamei sua atenção [dos socialistas europeus derrotados] para um povo cujo modo de vida incorporava mais condições favoráveis a uma revolução econômica do que o dos povos ocidentais. Chamei atenção para um povo (...) que fincava o pé sobre a terra e acreditava que esta terra era sua propriedade.

Tenho pregado isto há quinze anos. Minhas palavras despertaram risos e indignação, porém não me abalei. Então veio a Guerra da Crimeia e as risadas tornaram-se vaias e calúnias. Mas ainda assim continuei em meu caminho. Por uma estranha ironia do destino, tive de pregar no Ocidente, sobre as ruínas da República Francesa, algumas das ideias que Khomiakóv e os Kireiévski [autores eslavófilos clássicos] tinham pregado nos anos 40 e que eu, naquela altura, disputava. ${ }^{25}$

Este trecho evidencia toda a complexidade da posição política de Herzen, especialmente se considerarmos a trajetória que produziu esta síntese final feita pelo próprio autor. A segunda parte do presente trabalho ocupa-se dessa trajetória, analisada paralelamente à de Dostoiévski, visando a uma síntese dos problemas russos ligados à questão da nacionalidade e da alteridade europeia no século XIX. Mas, antes da comparação propriamente dita, precisamos conhecer melhor o universo de Dostoiévski.

\footnotetext{
${ }^{25}$ A. I. Herzen, "Letters to an Opponent". Selected Philosophical Works. Foreign Languages Publishing House,
} Moscou: 1956, p. 550. 


\section{Capítulo 2 - F. M. Dostoiévski: Cultivar o Solo Pátrio}

Pelo fato de ter sido um russo de origem nobre que viveu no século XIX, Fiódor Dostoiévski (1821-1881) teve uma educação à europeia. Basta ler a correspondência que manteve com o irmão Mikhail na juventude, antes do exílio na Sibéria, e testemunhar o êxtase com que os dois irmãos discutiam a literatura e as artes do Ocidente, sua devoção a Shakespeare e a Cervantes, para ter certeza de que a alma russa de Dostoiévski nutriu-se desde o princípio dos melhores frutos ocidentais. Também o marcou desde cedo um profundo interesse por todas as coisas russas, decerto, mas é preciso observar que, enquanto apaixonado patriota, Dostoiévski foi também, inegavelmente, um russo de seu tempo e, assim, foi como todos os seus contemporâneos de origem nobre um russo à europeia, de modo que não poderia negar absolutamente a cultura ocidental sem negar em parte a si mesmo.

Essa é a base da atitude conciliatória que acompanhou Dostoiévski ao longo das duas décadas (1860-1880) em que fez parte ativamente do debate sobre o futuro da Rússia e seu caráter nacional. Enquanto os eslavófilos "puros" adquiriam uma perfeita educação europeia para então defender o fechamento da cultura russa a influências estrangeiras, Dostoiévski manteve um posicionamento mais coerente com sua própria biografia, sempre visando a um equilíbrio entre a "alma russa" e a civilização ocidental quando o assunto era o desenvolvimento de seu país.

A trajetória das afinidades político-ideológicas de Dostoiévski é bem conhecida, ao menos em sua versão simplificada. Simpatizante do humanismo socialista nos anos 40, quando viveu seu primeiro período de glória literária com o sucesso de seu primeiro romance, Gente Pobre, ele seria preso em 1849 por participar do círculo de debates que se reunia em torno do fourierista Mikhail Petrachévski. Condenado primeiro à morte, depois a trabalhos forçados na 
Sibéria, o escritor passa dez anos no exílio, quatro dos quais em convívio cerrado com os detentos do que ele posteriormente chamou de "Casa dos Mortos", experiência seminal que lançou as bases do nacionalismo cristão e populista (naródnik) por ele esposado nas duas décadas seguintes.

Wayne Dowler explica:

\begin{abstract}
Mesmo em seu período mais radical nos anos 40, Dostoiévski fora um utópico e não um socialista revolucionário. O socialismo representava para Dostoiévski e seus contemporâneos um humanitarismo idealístico, (...) uma doutrina universalista cujo objetivo último era a irmandade de todos os homens, independentemente de suas origens sociais e nacionais. Em sentido amplo, Dostoiévski nunca repudiou o Cristianismo de sua infância, mas durante seus anos na prisão sua fé aprofundou-se. (...) Na prisão ele se deu conta pela primeira vez de que os sonhos cosmopolitas e socialistas de sua juventude eram contrários à nacionalidade que lhe fora revelada a partir de seu contato com o oprimido povo russo. Dostoiévski não deixou de lado sua fé no humanitarismo universal, mas agora o combinava com a noção patriótica do "lugar de cada um" (svoio mesto). ${ }^{26}$
\end{abstract}

Para os fins do presente trabalho, interessa-nos acompanhar Dostoiévski desde o momento de seu retorno a São Petersburgo, no final de 1859, após dez anos de exílio. É um momento crucial na história do século XIX russo, por marcar a transição entre a "era amordaçada" de Nicolau I (morto em 1855) e o período de renascimento do debate público sob Alexandre II, o "tsar libertador”. Dostoiévski deixara, em 1849, a mesma Rússia habitada por Herzen - a Rússia dos círculos de debate secretos, da impossibilidade de ação - e agora retornava para encontrar uma sociedade alvoroçada pela iminência de reformas transformadoras,

${ }^{26}$ DOWLER, p. 66. 
a começar pela principal, a quase idílica libertação dos camponeses. Florescia então a cultura das revistas grossas e das críticas mais ousadas ao status quo - e muitos intelligenty acreditavam tratar-se do fim dos tempos de discórdia ideológica em seu país. Se era utópico esperar pela supressão de todas as diferenças, a expectativa pela inclusão dos camponeses na vida pública russa era grande o suficiente para unir os grupos mais diversos sob a bandeira da justiça social.

É nesse contexto de grandes esperanças, debates públicos calorosos e confraternização da intelligentsia que Dostoiévski faz seu retorno às letras russas. Não é, portanto, sem forte motivação de seus arredores sociais que ele se engajará, na primeira metade da década de 60, em um movimento cuja principal bandeira será a promoção de uma "síntese cultural” em seu país. Conhecido como Pótchviennitchestvo (почвенничество), ou Movimento do Solo Pátrio ${ }^{27}$, teve origem na revista Vriêmia, editada pelos irmãos Mikhail e Fiódor Dostoiévski em colaboração com Apolón Grigóriev, Nikolai Strákhov e outros. O lançamento da revista, em fins de 1860, foi marcado pela publicação de um manifesto assinado por um autor anônimo (embora todos soubessem tratar-se do ex-preso político Fiódor Dostoiévski ${ }^{28}$ ), onde se expunham as diretrizes ideológicas da nova publicação:

Nós não buscamos nossos ideais na Moscou antiga [Eslavofilismo]; nós não dizemos que primeiro tudo tem de ser transformado à maneira alemã e que apenas então poderemos considerar nossa nacionalidade material digno da construção de um edifício futuro e eterno [Ocidentalismo]. Nós trabalhamos apenas com o que presentemente existe e queremos apenas dar maior liberdade de desenvolvimento ao que já é. Havendo tal liberdade de

\footnotetext{
${ }^{27}$ Não há, nas línguas latinas, tradução perfeitamente adequada ao termo Pótchviennitchestvo. Uma tentativa de tradução ao pé da letra seria solonativismo, porém ainda nos soa pouco natural. Adoto aqui a tradução livre utilizada por Wayne Dowler em seu livro Dostoevsky, Grigor'ev, and Native Soil Conservatism, "Native Soil Movement", ou "Movimento do Solo Pátrio".

${ }^{28}$ FRANK, Joseph. Os Efeitos da Libertação (1860 a 1865). Ed. Edusp, p. 68.
} 
desenvolvimento, nós acreditamos na Rússia do futuro; acreditamos no seu potencial independente. (...)

Não estamos, aqui, falando sobre Eslavófilos e Ocidentalistas. Nossa era é completamente indiferente às suas querelas domésticas. Estamos falando sobre a reconciliação da civilização com o princípio nacional. Acreditamos que ambas as partes devem enfim chegar a uma compreensão mútua, superar todos os mal-entendidos que se acumularam entre elas em número inacreditável, e então devem avançar em concórdia, combinando forças ao longo de um novo, amplo e glorioso caminho. União a todo custo, a despeito de todos os sacrifícios e o mais rápido possível - eis a ideia que nos motiva, eis nosso moto. ${ }^{29}$

Como se vê, o principal objetivo de Vriêmia ao veicular o Movimento do Solo Pátrio era revisitar o velho problema da relação Rússia-Ocidente, o qual englobava alguns tópicos fixos: elite educada/ocidentalizada x camponeses; Rússia petrina x Rússia moscovita; tendências ocidentalistas $\mathrm{x}$ eslavófilas entre a intelligentsia. Para os pótchvienniki, as duas esferas da realidade russa expressas nesses conflitos diziam respeito, respectivamente, à mente e ao corpo do país, ao pensamento em oposição à vida, esferas que precisavam com urgência ser reconciliadas - o que Dostoiévski e seus comparsas criam só pudesse ser feito por meio do retorno ao solo pátrio, às tradições tipicamente russas preservadas no coração do povo simples. Isto se reporta à visão de mundo mais geral dos pótchvienniki, para quem o pensamento só é eficaz se conectado com a vida concreta: "Confundir o pensamento incompleto com a realidade completa - eis a fonte de todos os erros da humanidade. ${ }^{30}$ Enquanto os intelectuais russos existissem e pensassem ignorando sua realidade mais imediata, isto é, os valores e o modo de

\footnotetext{
${ }^{29}$ Apud DOWLER (1982), p. 90-91.

${ }^{30}$ Dostoiévski, artigo sobre Dobroliúbov. Vriêmia, março de 1862.
} 
existência da esmagadora maioria de seus conterrâneos, estavam fadados ao pensamento inócuo, inconsequente; pois o homem alienado de sua própria nacionalidade está necessariamente impossibilitado de compreender a si mesmo e, portanto, de compreender o que quer que seja.

Ao mesmo tempo, metonimicamente (o homem está para a nação como esta para o mundo), só é possível a uma nação contribuir com o andamento da História se estiver em posse de seus próprios recursos originais e particulares. E somente intelectuais conscientes de sua nacionalidade própria formarão uma nação autoconsciente, capaz de contribuir com o "objetivo final da humanidade":

Nós não consideramos a nacionalidade [natsional'nost'] como a palavra última ou o objetivo final da humanidade. Somente a humanidade universal pode viver uma vida completa. Mas os homens alcançarão isto de nenhum outro modo senão pela ênfase na nacionalidade única de cada povo. A ideia do solo, das nacionalidades, é o fulcro. ${ }^{31}$

Esse raciocínio também pretendia combater a ideia ocidentalista de que as regras universais da civilização humana já haviam sido descobertas pela Europa ocidental, sendo necessário apenas que se propagassem pelo mundo. Para os pótchvienniki, "cada nação faz uma contribuição especial à totalidade da experiência humana e cada qual é governada por uma ideia ou princípio particular que de início vive inconscientemente na vida de seu povo e vai emergindo à consciência de forma gradual. O destino de uma nação está, portanto, contido em sua essência." ${ }^{32}$ Conseguintemente, o Movimento do Solo Pátrio considera a história de uma nação

\footnotetext{
${ }^{31}$ Dostoiévski em artigo sobre Dobroliúbov, Vriêmia, 1863.

${ }^{32}$ DOWLER, p. 78.
} 
como um todo orgânico, do qual nenhum momento pode ser desconsiderado ou diminuído a mero estágio preparatório para o que vem a seguir. ${ }^{33}$

Dessa concepção orgânica da sociedade e das relações entre as sociedades, sincrônica e diacronicamente, deriva por fim a importância dada pelos pótchvienniki ao desenvolvimento da personalidade individual. Trata-se, na verdade, do mesmo raciocínio que os faz valorizar a imersão do homem em seu universo nativo: o autoconhecimento como condição de possibilidade do conhecimento em geral. Por um lado, eles consideravam a conquista do "objetivo último" da humanidade como um processo cooperativo, social e transnacional, mas, por outro, percebiam que o vigor e o caráter de cada sociedade eram dados pela somatória de seus indivíduos. Para além da conformação à doutrina pótchviennik, que Dostoiévski ajudou a desenvolver, o primado da liberdade e do desenvolvimento individual frente a questões sociais era uma de suas intuições primeiras, verdadeira pedra-de-toque de seu pensamento.

Para que o esforço conciliatório do Pótchviennitchestvo tivesse eficácia cultural, era necessário que ele não se confundisse com nenhuma das tendências ideológicas correntes ou anteriores - nem Eslavofilismo, nem Ocidentalismo, nem o materialismo radical que já despontava àquela época. Como enfaticamente expresso no manifesto, o Movimento do Solo se queria uma síntese total e que ao mesmo tempo trouxesse algo de novo ao cenário de debates russo. E, com efeito, há diferenças marcantes entre as ideias veiculadas em Vriêmia e as de seus concorrentes contemporâneos e anteriores.

Com relação aos eslavófilos, uma primeira diferença importante é que estes diferenciavam a Rússia e o Ocidente por um critério religioso: a Europa vivia sob o Catolicismo, sendo portanto marcada pelo racionalismo romano, enquanto a Rússia, com a Ortodoxia,

\footnotetext{
${ }^{33}$ Dostoiévski, “Ряд статей о русской литературе”. Vriêmia, 1861.
} 
preservara a integridade interior do amor de Cristo ${ }^{34}$. Dostoiévski nos é hoje conhecido por sua defesa acalorada da religião ortodoxa e correspondente condenação do Catolicismo romano; porém, no período imediatamente após seu retorno do exílio siberiano, este aspecto de seu pensamento ainda não tinha a importância que viria a ter mais tarde. Ele e os demais pótchvienniki não entendiam a nacionalidade russa em termos preponderantemente religiosos, como os eslavófilos, mas acreditavam que o fator distintivo de sua nação era o dom para o universalismo cultural, pelo qual a Rússia lograria fundir as ideias do Ocidente às suas próprias.

Esta primeira discordância entre pótchvienniki e eslavófilos leva à discordância principal, relativa às reformas de Pedro, o Grande. Para os eslavófilos, Pedro fora a origem, na Rússia, da separação entre vida e conhecimento, pois toda verdadeira educação deve se dar pela integração do sujeito pensante com o princípio nacional. Os pótchvienniki, como vimos, concordam com isso, mas não veem apenas este aspecto negativo das reformas petrinas. Eles consideram, pelo contrário, que estas foram reformas absolutamente necessárias ao desenvolvimento da Rússia, pois o povo russo tende inconscientemente ao universal, e Pedro respondeu a essa necessidade. Porém, as reformas por ele empreendidas não foram eficazes, por terem sido antinacionais. ${ }^{35}$ É um raciocínio sutil, mas compreensível: considera-se que o povo russo é marcado por duas características fundamentais: o universalismo, que o faz compreender e assimilar valores e ideias estrangeiros, e a fraternidade, que é seu traço nacional típico. No período anterior às reformas de Pedro, o povo russo estava aquém de seu potencial para o universal, por seu isolamento do resto do mundo; as reformas petrinas foram boas ao possibilitar que ao menos parte da população avançasse nesse sentido, mas foram incompletas ao desprezarem os valores tipicamente nacionais, sem os quais o universalismo russo também não se cumpre.

\footnotetext{
${ }^{34}$ Este raciocínio eslavófilo deve muito a Tchaadáiev, sendo que este, como se sabe, invertia a conclusão final e creditava o atraso da Rússia à adoção da religião ortodoxa em vez do Catolicismo.

${ }^{35}$ Cf. Dostoiévski, in: “Два лагеря теоретиков”. Vriêmia, Janeiro-Fevereiro 1862.
} 
É assim que, para os pótchvienniki, a elite educada e o povo compõem juntos a nacionalidade russa, encarnando, respectivamente, os dois traços fundamentais da nação: a universalidade e a fraternidade. Os homens do solo rejeitam, portanto, a ideia de que na Rússia pós-petrina há uma cisão absoluta entre essas duas classes (como queriam os eslavófilos):

Por que a nacionalidade deveria pertencer apenas ao povo simples? A nacionalidade por acaso desaparece quando o povo se desenvolve? Será que nós, os educados, também não somos o povo russo? Parece-nos dar-se justamente o oposto: com o desenvolvimento do povo, de todos os seus dons naturais, toda a sua riqueza se desenvolve e se fortalece e seu espírito brilha mais intensamente. (...) Sabemos apenas que fomos divididos por circunstâncias puramente externas. Tais circunstâncias externas não permitiram que a massa do povo nos seguisse, aí inclusas todas as forças do espírito nacional. Sabemos apenas que nós somos uma parte muito separada e muito pequena do povo e que, se o povo não nos seguir, nunca estaremos aptos a nos expressar completamente (...), não como nos expressaríamos se a totalidade do povo russo estivesse conosco. ${ }^{36}$

Não só os textos de Vriêmia, mas também a literatura de Dostoiévski é marcada pela ideia de que o homem russo educado, por mais que se queira ocidental, não consegue livrar-se de sua nacionalidade arraigada. Essa é a tensão que caracterizará os indivíduos cindidos da grande literatura dostoievskiana, dos quais são emblemáticos o Homem do Subsolo, Raskólnikov, Ivan Karamázov e tantos outros. E a solução proposta por Dostoiévski a esses heróis deslocados de seu eixo moral é justamente o princípio conciliatório do Pótchviennitchestvo - por exemplo, quando a redenção de Raskólnikov se dá a partir de sua união com Sônia, a qual encarna o solo, o princípio nacional russo.

\footnotetext{
${ }^{36}$ Dostoiévski, “Ряд статей о русской литературе. Книжность и грамотность.” Op. Cit.
} 
Já quanto aos ocidentalistas, os autores de Vriêmia também dedicavam a eles algumas de suas críticas mais mordazes, embora sempre dentro da moldura conciliatória de quem tenta ver aspectos positivos no que critica. O Ocidentalismo russo clássico, surgido na esteira da reação eslavófila à Primeira Carta Filosófica de Tchaadáiev, era considerado pelos pótchvienniki como exemplar do pensamento inócuo, fadado ao fracasso, posto que desenraizado de suas circunstâncias nacionais e totalmente alheio aos fatos e necessidades reais da vida russa. Ainda assim, era preciso extrair o melhor significado possível também do pensamento ocidentalista, o que os homens do solo faziam associando-o ao mesmo desejo de universalidade por meio do qual salvaram as reformas petrinas. Dostoiévski dizia-se convencido de que os ocidentalistas foram para os russos "o despontar da consciência, o início da força de vontade, o início de novas formas de vida ${ }^{37}$, ainda que considerasse irrisório o valor substantivo de suas.

Em suma, os pótchvienniki consideravam que, em sua época, em meados do século XIX, todos os objetivos civilizacionais das reformas petrinas tinham sido alcançados; agora, para completar a jornada, era urgente incentivar o retorno da totalidade do povo russo à realidade do solo pátrio, corrigindo, por assim dizer, o aspecto defeituoso (antinacional) do projeto de Pedro I. Mas por "incentivar" eles entendiam a mera propagação de ideias e o convencimento intelectual e moral da população, especialmente a intelligentsia, e nunca um programa revolucionário de modificação da sociedade à força.

Dostoiévski acreditava que "uma sociedade pode acomodar apenas o nível de progresso para o qual se desenvolveu e o qual já começou a compreender. (...) A mudança revolucionária impõe ideias e instituições a uma sociedade despreparada para recebê-las. As revoluções

\footnotetext{
${ }^{37}$ Dostoiévski, “Ряд статей о русской литературе.” Op. Cit.
} 
invariavelmente destroem mais do que seus resultados justificam." ${ }^{38}$ Já desde o julgamento que o condenou ao exílio siberiano ${ }^{39}$, o romancista cultivava a ideia de que na Rússia não há antagonismos étnicos (pois a população é toda composta de uma mesma raça), de modo que, diferentemente da Europa, seus problemas poder-se-iam resolver de modo pacífico.

É assim que um dos tópicos recorrentes em Vriêmia será o da educação, com especial ênfase na alfabetização (gramotnost') do povo simples: "De nossa parte, estamos completamente convencidos de que a alfabetização melhorará o povo do ponto de vista moral e dará a ele um senso de seu próprio valor, o que por sua vez eliminará muitos abusos e depravações, eliminando mesmo sua possibilidade." ${ }^{40}$ Educar o narod era de inteira responsabilidade da classe educada, não apenas pelo dever fraterno de fazer o bem ao próximo, mas porque, segundo a filosofia pótchviennik, a união com o povo representava a única esperança para o futuro de toda a Rússia. E, para não se pensar que os autores de Vriêmia jamais desciam do Olimpo das virtudes morais, acrescente-se que eles também tinham em mente a educação como princípio do desenvolvimento econômico de seu país:

A questão do nível de desenvolvimento moral de um segmento particular do público leva diretamente à questão da educação, do esclarecimento, do desenvolvimento intelectual. Nós devemos agora tomar medidas decisivas para propagar a educação. Isto é essencial também por razões econômicas. Nosso interesse, à parte nosso valor enquanto seres humanos, o demanda. A transformação do setor judicial precisa de uma quantidade enorme de advogados; (...) em vários moinhos e fábricas há uma necessidade extrema de químicos, tecnólogos, mecânicos e mineralogistas; a deficiência universal das estradas requer

\footnotetext{
${ }^{38}$ Dostoiévski, “Neizdannyi Dostoevskii”, Literaturnoe nasledstvo, LXXXIII. Moscou: 1971, p. 176. Apud DOWLER, p. 200.

${ }^{39}$ Cf. FRANK, Joseph. Os Efeitos da Libertação - 1860-1865, pp. 69-70.

${ }^{40}$ Dostoiévski, “Ряд статей о русской литературе." Op. Cit.
} 
engenheiros; por fim, o espírito do tempo demanda cidadãos honestos e moralmente desenvolvidos, e quem pode controlar o espírito do tempo? Que ninguém sequer tente: ele não pode ser controlado. ${ }^{41}$

Este trecho atesta o caráter progressista do Pótchviennitchestvo, o qual de modo algum se tratava de um movimento pela conservação do estado de coisas na Rússia imperial. Naquele momento, as causas esposadas pelos grupos mais abertamente à esquerda coincidiam quase que integralmente com as dos pótchvienniki. A divergência entre uns e outros estava sobretudo no método para se buscar a mudança, com o grupo encabeçado por Dostoiévski repudiando absolutamente a ideia de uma revolução política e centrando seu programa na revolução moral individual. Dowler sintetiza:

O intenso humanismo dos pótchvienniki nunca foi tão evidente quanto nos meios por eles propostos para se chegar à mudança social na Rússia. Eles não advogavam nem coerção social severa, nem abertura revolucionária. Antes, colocavam sua fé no indivíduo, no valor moral da personalidade autônoma. Em sua visão, a coerência social e a continuidade histórica eram produtos da criatividade livre dos indivíduos, os quais existiam em uma relação orgânica com seus próprios tempo e espaço. Era o indivíduo que, respirando o ar ao seu redor - para usar a metáfora de Grigóriev -, criava os valores da sociedade, e não a sociedade que impunha seus valores convencionais ao indivíduo. Aí estava a essência, para os pótchvienniki, do progresso moral e também da nacionalidade. Pois a nacionalidade (natsional'nost') era a reflexão, na arte, nas atitudes sociais e nas instituições políticas e sociais, do nível moral consciente de uma nação em um dado momento. ${ }^{42}$

\footnotetext{
${ }^{41}$ Autor anônimo, “Наши домашние дела”, Vriêmia, Outubro de 1863.

42 DOWLER, p. 102.
} 
Contudo, outra diferença marcante entre os pótchvienniki e o pensamento político dos grupos mais à esquerda era que o Movimento do Solo se posicionava em defesa da autocracia tsarista, embora repudiasse o burocratismo e o clima de repressão cultural típicos do reinado de Nicolau I. Apoiar a autocracia, para eles, era uma decorrência natural de sua crença no "espírito da nação russa". O conservadorismo de Dostoiévski e dos homens do solo visava à conservação de tudo o que fosse tipicamente nacional, e não de formas antigas pelo simples fato de serem antigas. O critério de diferenciação entre uma coisa e outra não fica muito claro; podemos depreender, no máximo, que eles consideravam o tsarismo como uma expressão do espírito russo por sua larga aprovação junto aos camponeses e por refrear a mentalidade revolucionária a qual os intelligenty ocidentalistas queriam impor ao país, embora fosse inegavelmente estranha aos valores do povo. Nas palavras de Dostoiévski: "O Estado precisa do tipo de conservadorismo que é baseado em tradições nacionais e defende tudo o que há de razoável no passado - o espírito do povo e seus interesses -, que examina e critica todas as novas necessidades da vida social. Este conservadorismo será uma verdadeira força conservadora." ${ }^{43}$

Nikolai Strákhov, em suas memórias, faz um relato sucinto sobre as ideias políticas dos pótchvienniki:

No campo prático, nós seguíamos o liberalismo puro, isto é, a doutrina que discorda sobretudo da ideia de um levante por meio da força e, se insiste em quaisquer mudanças na ordem social, busca assegurar tais mudanças exclusivamente por meio da convicção e da persuasão. O liberalismo puro, como se sabe, é a fé de que a ausência de medidas compulsórias levará a melhores resultados para a autoridade social, de que sob tais condições os interesses de todos serão entendidos com maior correção, equilibrando-se mutuamente. Em

\footnotetext{
${ }^{43}$ Dostoiévski, “Дворянство и земство”, Vriêmia, Março de 1862.
} 
uma palavra, são os princípios esposados pelos partidários da liberdade de pensamento, de expressão, de mercado, etc, princípios esses que, obviamente, podem estar longe de atingir seus objetivos, mas devem ser estimulados na maioria dos casos onde não há uma base clara para outros modos de ação. Portanto, a mensagem liberal é factível e útil sob qualquer forma de governo, embora não ofereça uma teoria da sociedade completa e bem definida. Outros princípios, que tenham maior força e urgência, devem presidir sobre esses princípios [liberais]. ${ }^{44}$

Um desses princípios mais urgentes e mais fortes (capazes de guiar a execução prática dos princípios liberais) era divisado pelos pótchvienniki no associacionismo ou coletivismo do povo russo. A comuna camponesa será para eles, como para Herzen e tantos outros populistas dessa geração e da próxima, o elo entre o ideal liberal-progressista e a realidade concreta. Diferentemente da Europa, os russos não se atinham a meros discursos pró-fraternidade - eles a viviam cotidianamente, e como expressão de sua própria natureza, sem ninguém lhes ter ensinado. "A comuna livre tem sido desde tempos imemoriais a forma preferida de comunidade do povo russo, e sua restauração em sua forma original não será na prática uma tarefa irrealizável." ${ }^{, 45}$ Cabia, portanto, às classes educadas da Rússia valer-se desse trunfo nacional, agregando a ele os avanços tecnológicos do Ocidente para expandir suas potencialidades.

Este é um novo ponto atestando a abertura do Pótchviennitchestvo ao progresso da época, na esteira da evolução científica e tecnológica do Ocidente. Embora, como veremos nas Notas de Inverno, Dostoiévski tivesse horror aos efeitos sociais do capitalismo industrial e à moral burguesa que o sustentava, Vriêmia não se fechava à possibilidade de uma industrialização

\footnotetext{
${ }^{44}$ N.N. Strákhov, “Воспоминания о Федоре Михайловиче Достоевском", Biografia, pis'ma, p. 229. Apud Dowler, p. 105.

${ }^{45}$ A. Poriétski, “Преобразование городского общественного управления”, Vriêmia, Janeiro de 1863.
} 
benéfica, infundida do espírito associacionista russo, pois muito pior do que buscar alternativas nesse sentido seria deixar o país simplesmente estagnar-se:

Sem a indústria que modifica a condição e a forma de matérias primas e as adapta à satisfação de várias necessidades, sem a indústria que supre todas as mais importantes demandas, o país será sempre puramente agrícola e permanecerá para sempre pobre e, consequentemente, ignorante. Estas duas qualidades, reforçando uma à outra, eventualmente reduzirão o país a um estado de completa selvageria em comparação com o progresso o qual, enquanto isso, será alcançado inevitavelmente por outros países mais desenvolvidos. ${ }^{46}$

Assim, vemos que para todas as questões da vida russa os pótchvienniki propunham uma solução média, isto é, conciliando opostos aparentemente conflituosos. Essa será a linha editorial de Vriêmia, que, ainda assim, viria a ser fechada pelo governo em 1863. Em 1864, os irmãos Dostoiévski conseguem permissão para publicar um novo periódico, Epókha, no qual dão continuidade a sua cruzada pela unidade da cultura russa. Contudo, nesse momento as ideias de Dostoiévski já estão mais próximas do que viriam a ser em sua fase madura, apresentando um tom eslavófilo mais acentuado. Tanto sua atividade em Vriêmia, onde ele travou intensos debates com a intelligentsia radical, quanto sua primeira viagem à Europa, em 1862, foram cruciais à delimitação das ideias que sustentariam seus grandes romances, os quais viriam em seguida. É nesse período que Dostoiévski chega à conclusão de que uma ordem social baseada no amor cristão e na fraternidade é impossível na Europa, embora ainda seja uma possibilidade ao povo russo, e é também o momento em que ele passa a associar a religião católica ao socialismo e a opor ambos, como uma coisa só, ao seu ideal de uma "fraternidade naródnik em Cristo".

${ }^{46}$ Autor anônimo, “Наши домашние дела”, Op. Cit. 
À medida que avançam os anos 60, a baixa qualidade moral do povo russo, expressa nas Recordações da Casa dos Mortos (1860-62), vai sendo matizada, aos olhos de Dostoiévski, pela tendência das classes populares à fraternidade, tendência essa que se torna ainda mais significativa à luz da história de opressão do narod. Um povo que se mantém temente a Deus e capaz de viver comunalmente mesmo em meio a circunstâncias de intensa miséria e barbárie há de carregar em seu espírito comum um dom para a fraternidade. A sociedade perfeitamente fraterna seria aquela em que todos se unem em um esforço de autodoação, seguindo o comando de Cristo para amar ao próximo como a si mesmo - coisa de que só o povo russo seria capaz instintivamente, isto é, sem sequer precisar esforçar-se.

Para Dostoiévski, a existência humana é marcada pela irracionalidade e por maldade e bondade gratuitas; a única força capaz de conter a autodestruição do ser humano é a consciência de sua imortalidade. A importância do narod está diretamente ligada a essa ideia, pois, como veremos ao longo deste trabalho, o pensamento político-filosófico de Dostoiévski sustenta-se sobre duas grandes máximas: 1) o homem que rejeita sua condição de ser imortal está fadado a entregar-se à barbárie mundana; 2) num século marcado pelo avanço do ateísmo revolucionário, o narod russo, em quem se preservaram da influência europeia os ensinamentos de Cristo, é a luz capaz de reconduzir os homens - primeiro, os de seu país, em seguida, todos os demais - ao caminho de sua verdadeira dignidade transcendente.

Em 1864, Dostoiévski escreve em seu caderno de notas o que seria a sua ideia seminal dali em diante: a ideia da humildade cristã como virtude máxima e base da organização social perfeita:

Após o aparecimento de Cristo enquanto o ideal de homem encarnado, tornou-se claro como o dia que o desenvolvimento final e mais alto da personalidade coincide com o 
ponto no qual o homem descobre, sabe e acredita com toda a força de sua natureza que o supremo uso que pode fazer de sua personalidade, da inteireza do desenvolvimento de seu ego, é eliminar este ego, entregá-lo de todo o coração e desinteressadamente. E esta é a maior das felicidades. Deste modo, a lei do ego une-se à lei do humanismo e, nesse entrelaçamento, o ego e a coletividade aniquilam-se mutuamente, ao mesmo tempo em que cada um alcança a seu modo o ápice de seu desenvolvimento individual.

Este é o paraíso de Cristo. Toda a história da humanidade é apenas o desenvolvimento, o embate, a aspiração ao cumprimento deste objetivo. ${ }^{47}$

Em vez da síntese cultural baseada na psicologia do povo russo, proposta pelo Pótchviennitchestvo, os textos de Epókha, como no trecho acima, estarão mais próximos do pensamento eslavófilo, ao interpretar não só a psicologia, como também o passado, o presente e o futuro da Rússia em função da religiosidade cristã ortodoxa, uma vez que a realização social do mencionado "paraíso de Cristo" começaria necessariamente pela preponderância dos valores do narod russo sobre os da civilização ocidental.

Neste momento, a base intelectual e moral do Dostoiévski maduro está formada. Daqui em diante seus textos apenas desenvolverão - em alguns pontos chegando ao limite do razoável - as ideias expressas nesse período pós-Vriêmia. E aí reside a centralidade das Notas de Inverno Sobre Impressões de Verão ao desenvolvimento intelectual e artístico de Dostoiévski: elas marcam a transição entre o discurso pótchviennik e o mais propriamente eslavófilo na obra do escritor, segundo veremos a seguir, tendo sempre Herzen como contraponto.

\footnotetext{
${ }^{47}$ Dostoiévski, “Neizdannyi Dostoevskii", p. 173.
} 


\section{PARTE II - Dois viajantes}

\section{Capítulo 1. Aspectos gerais dos dois relatos de viagem}

\subsection{Cartas de França e Itália}

Herzen deixa a Rússia já com a intenção de produzir um relato de suas experiências de viagem $^{48}$. A necessidade de manter contato com seus conterrâneos dar-lhe-ia também ocasião para refletir sobre a questão da identidade nacional russa em função do outro europeu. É assim que nascem as Cartas de França e Itália, relato significativo em pelo menos dois níveis fundamentais: 1) o dos acontecimentos políticos europeus de 1847-51 e 2) o das profundas mudanças verificadas na personalidade e no pensamento de Herzen nesse período.

Mas as Cartas não foram a única obra composta nos primeiros anos de exílio do escritor. Paralelamente, Herzen também produziu o importantíssimo Da Outra Margem, que complementa sua reflexão sobre a tentativa revolucionária de 1848, e ainda os textos que lançam a base de sua doutrina do Socialismo Russo, dos quais os principais são os ensaios Sobre o desenvolvimento das ideias revolucionárias na Rússia e $O$ povo russo e o socialismo, ambos de 1851. Todas essas obras compõem a tentativa de Herzen de integrar-se ao mundo europeu, seja refletindo sobre ele (Cartas e Da Outra Margem), seja divulgando a história e a cultura russas e ajudando a desfazer preconceitos europeus sobre sua terra natal (textos relativos ao Socialismo Russo).

\footnotetext{
${ }^{48}$ Cf. carta a Ogarióv, 3 de agosto de 1847, apud ZIMMERMAN, p. xiv.
} 
Assim, no período que antecede o estabelecimento definitivo de Herzen em Londres, em 1852, sua atividade intelectual atua nessas duas frentes: uma com foco no Ocidente, outra com foco na Rússia. À medida que o desencanto de 1848 se firma (junto a outros desencantos pessoais dos quais falaremos mais adiante), a soma dessas duas frentes toma o sentido que será o de seus textos da década de 50 - de que ao Ocidente decrépito corresponde o despontar do Povo Eslavo, entre outras ideias de mesmo cunho, que valeriam a Herzen o título de pai do movimento populista russo.

As Cartas de França e Itália devem ser lidas tendo em vista essa sua contraparte nacional-populista. Se ao início a proposta era a de um relato distanciado e objetivo, ao longo de sua composição (que se estendeu por cinco anos) elas vão se tornando cada vez mais em veículo das ideias políticas e sociais de Herzen, e seu formato final casa perfeitamente com a doutrina do Socialismo Russo ${ }^{49}$, ao descrever a degeneração da sociedade europeia, francesa sobretudo, abrindo caminho à novidade eslava.

As Cartas se dividem em quatro grupos:

- “Cartas da Avenida Marigny”: quatro cartas escritas em Paris durante a primavera e o verão de 1847 e publicadas no mesmo ano no jornal russo Sovriemiênik. Seu tema principal é a caracterização da burguesia francesa e da Monarquia de Julho de LouisPhilippe.

- "Cartas da Via del Corso": quatro cartas escritas na Itália, onde Herzen morou de novembro de 1847 a abril de 1848. Não puderam ser publicadas no Sovriemiênik devido

\footnotetext{
${ }^{49}$ Cf. Capítulo III, abaixo.
} 
ao aumento das restrições à imprensa russa após o início dos levantes revolucionários na Europa. Nessas cartas Herzen descreve a atmosfera italiana no período imediatamente anterior à eclosão do levante de Palermo em janeiro de 1848.

- "De novo em Paris": três cartas escritas em Paris. Descrevem a reação precipitada pelo fracasso do levante socialista de 15 de maio de 1848. Foram escritas mormente para circulação entre amigos de Herzen.

- Reflexões tardias sobre 1848: três cartas datadas de 1850-51, escritas em Nice, e um último adendo, "Carta a M. Ribeyrolles".

Ao todo são, portanto, quinze cartas, a serem referidas daqui em diante pelo respectivo número ordinal, correspondendo a primeira carta à primeira do ciclo da Avenida Marigny e a décima quinta à endereçada a Ribeyrolles, seguindo a ordem adotada nas edições do ciclo completo publicadas em Londres em 1854 e 1858. Além do texto original, utilizei como referência a tradução de Judith Zimmerman, Letters From France and Italy (University of Pittsburgh Press, 1995), à qual se refere a numeração de páginas acompanhando citações do texto, ao longo da análise.

Devemos notar, inicialmente, que o travelogue de Herzen é verídico: à parte elaborações posteriores, foram cartas escritas sobre fatos reais observados por um viajante de carne e osso, que as assina com seu próprio nome e tem a intenção sincera de usá-las como meio de comunicação com um público específico - a intelligentsia de seu país. Tudo isso inicialmente distancia as Cartas de França e Itália da ficção, embora também não se possa tomá-las por um 
roteiro fiel e objetivo da jornada europeia de Herzen, pois, como se sabe, o texto escrito é o reino da recriação da realidade.

É assim que o narrador das Cartas é um Herzen romantizado, moralmente impecável, um observador refinado de arredores em decadência, aos quais se considera francamente superior. Offord e Acton enfatizam essa autoindulgência de Herzen, em oposição a Isaiah Berlin, para quem não há nele "nenhum traço de autodramatização byroniana",50. É difícil, porém, concordar com Berlin, diante da frequência com que Herzen permite-se, nas palavras de Offord, "controlar todos os encontros e diálogos, sempre capaz de proferir alguma tirada inteligente cuja ironia seu interlocutor não sabe apreciar." $"$ Acton discute a possibilidade de essa autodramatização narcisista, presente não só nas Cartas, mas de modo até mais acentuado em Passado $e$ Pensamentos, ser um recurso utilizado por Herzen para dar-se a si mesmo como modelo a ser seguido pelos intelligenty russos, ele mesmo a personificação dos ideais que defende, o espírito livre, autodeterminado, criador de suas próprias regras e valores, sempre justo com seus semelhantes e dedicado de corpo e alma à causa da libertação da humanidade.

Seja como for, não se trata de estilização suficiente para que se possa atribuir ficcionalidade às Cartas. Elas podem, de todo modo, ser enquadradas na tradição do relato de viagem russo e o próprio Herzen se esforça para fazê-lo ao início de seu texto, mencionando as obras de Fonvízin, Karamzin e Pogódin. Com efeito, há nas Cartas alguns dos elementos característicos do gênero relato de viagem, como a descrição de cenas de rua, paisagens, diálogos, considerações sobre a cultura local (teatro, ambientes sociais), e a afirmação usual do viajante de que seu texto é infundido de imediatismo e do frescor de impressões recentes.

\footnotetext{
${ }^{50}$ Introdução a From the Other Shore and The Russian People and Socialism, p. XVI.

${ }^{51}$ OFFORD, p. 180.
} 
Porém, a contribuição de Herzen à tradição do travelogue russo também já traz alguns elementos de subversão da forma genérica estabelecida. O principal é que se trata da descrição de uma jornada mais intelectual do que geográfica. Nas palavras de Herzen, é uma jornada entre “a estação de 1848 e a estação de 1852", ou entre o velho mundo representado pela burguesia europeia e o mundo da utopia socialista, o qual o viajante imaginava habitado por espíritos livres e inspirados pelo frescor eslavo, como ele próprio. Ou seja, há aqui a transgressão do grand tour clássico, onde o viajante saía de seus arredores particulares em busca de "tornar-se europeu", isto é, cidadão do mundo. Herzen deixa sua terra natal com uma mentalidade próxima a essa, mas a jornada modifica tanto os ideais quanto a personalidade do viajante e, ao fim, seu travelogue resulta em um grand tour invertido, no qual o contato com a civilização europeia serve como meio para que o autor se torne plenamente russo, vindo a conhecer-se melhor a si mesmo e a seu país de origem. É esse o sentido das famosas palavras de Herzen: "Eu comecei com um grito de alegria ao cruzar a fronteira e cheguei ao fim com meu retorno espiritual à minha pátria. A fé na Rússia me salvou a um passo da ruína moral. ${ }^{.52}$

O relato de viagem acaba sendo, portanto, uma entre as várias incursões de Herzen pelos gêneros autobiográficos que lhe seriam tão caros ao longo de sua vida, culminando em seu monumental Passado e Pensamentos. A descrição epistolar dos seus primeiros anos de exílio europeu permite-lhe organizar sua experiência durante um período de turbilhão existencial e ao mesmo tempo mapear o terreno de suas ideias políticas em constante movimento. Como bem notou Judith Zimmerman, o viés político foi o modo que Herzen encontrou para revisitar a tradição do relato de viagem russo oferecendo uma contribuição original, já que tal tradição surgiu, junto com a intelligentsia russa, do processo histórico responsável pela ocidentalização do país, e assim todos os autores-viajantes russos cruzam a fronteira já com um conhecimento

\footnotetext{
${ }^{52}$ Introdução à edição de 1858 das Cartas de França e Itália.
} 
prévio do Ocidente e a sensação de estarem visitando pela primeira vez uma terra com a qual têm íntima ligação. Quando Herzen escreve seu relato próprio, à intimidade escolar com a cultura europeia se somam os relatos anteriores de nomes emblemáticos como Karamzin e Fonvízin, o que o obriga a buscar um nicho não explorado nessa seara, nicho esse encontrado na crônica política, ou, como diria Derek Offord, no papel de turista revolucionário.

Offord também aponta corretamente que as Cartas de França e Itália têm dois protagonistas (além, é claro, do narrador): o odioso burguês francês e o virtuoso povo (o proletário parisiense e o camponês italiano). Herzen não poupa seu talento para a caricatura quando faz com que esses personagens encarnem seus mais caros ideais políticos. De fato, na representação de tipos sociais europeus exprime-se uma das características fundamentais das Cartas: o uso da crônica de costumes para sustentar certa leitura da História e ratificar as ideias políticas do autor.

Exemplar nesse sentido é a representação que Herzen dá, na segunda carta, aos trabalhadores domésticos franceses, donos de uma "insolência" que o autor-viajante vê com muito bons olhos, pois significa que "o empregado francês faz questão de servir como uma pessoa". Ele é, portanto, caprichoso e, após servir o chá a seu senhor, senta-se confortavelmente, no mesmo salão que este, para ler o jornal. Herzen atribui essa altivez da classe trabalhadora francesa à herança da revolução de 1789. Esses empregados "mimados" são filhos e netos dos soldados do "grande exército", e por mais que o governo reacionário tenha tentado apagar da memória desses "herdeiros da liberdade" a noção de sua dignidade pessoal, não obteve sucesso ${ }^{53}$.

\footnotetext{
${ }^{53}$ Num dos atos falhos que lhe são típicos, Herzen acrescenta à segunda carta um Post Scriptum muito interessante (p. 33-36). Ele comenta, com otimismo, o fato de que em Paris se precisa cada vez menos de empregados pessoais. O leitor, então, prepara-se para felicitar o autor por seu desprendimento anti-burguês, por estar à frente de seu tempo e, sendo um aristocrata, cuidar de suas próprias ninharias domésticas (vestir-se, separar sua correspondência etc). Mas eis que... Toda a novidade progressista proposta por Herzen consiste em substituir os empregados pessoais pelos senhorios da pensão! Certíssimo de que isto representa o cúmulo do
} 
Herzen, assim, usa a crônica de costumes para reiterar seu entusiasmo pela mitológica Revolução Francesa, transmitindo ao leitor, ao mesmo tempo, suas esperanças revolucionárias quanto ao presente - afinal, o proletário francês "é ainda mais desenvolvido moralmente do que o servo doméstico". Porém, há também momentos em que o comentário político é feito de forma direta, sem passar pela análise do ambiente social imediato. Essa é outra importante característica das Cartas de França e Itália: com frequência elas distanciam-se do gênero relato de viagem e aproximam-se do artigo jornalístico puro e simples, ou mesmo do relato histórico.

O mais comum é Herzen iniciar a carta com a descrição do ambiente onde se encontra, tanto do ponto de vista físico quanto cultural. Tendo abordado brevemente o momento presente da localidade, logo mergulha em seu passado e em sua história; em se tratando de cidades europeias, onde tudo remete às batalhas milenares de cujos banhos de sangue se erigiu o Ocidente, não poderia ser de outro modo, ao menos não quando o autor-viajante é Herzen. É assim que, na quinta carta, as primeiras páginas são um perfeito travelogue sobre a passagem do autor por Lyon, mas não demora até nos vermos transportados ao passado revolucionário da cidade, perdendo o texto inteiramente o aspecto de "guia turístico". Essa tendência afasta as Cartas do relato de viagem tradicional, na medida em que, ao que tudo indica, Herzen poderia ter feito muitas dessas considerações históricas sem jamais ter pisado na Europa. A visita aos cenários reais dos confrontos políticos descritos serve apenas de gatilho para que o autor recupere em sua memória tudo o que já sabe sobre esses lugares que está visitando pela primeira vez. Nesses trechos não se trata, portanto, de um relato de viagem.

desprendimento de hábitos sociais decrépitos, ele adverte o leitor de que possivelmente o senhorio se recusará a fazer serviços menores como "encher-nos o cachimbo ou trazer um lenço do outro quarto", mas tão melhor assim, pois "a vantagem moral de uma vida refinada [i.e. progressista] é que ela afasta os homens de costumes selvagens". Herzen era um nobre tão à frente de seu tempo que se dispunha inclusive a encher o próprio cachimbo. 
Herzen tinha uma veia de historiador fortíssima, porém, o fato de aqui empregá-la dentro da moldura de outro gênero de texto - o relato de viagem epistolar - diminui o poder de persuasão de suas análises históricas. O estilo despretensioso e intimista do travelogue faz de Herzen um historiador que não cita fontes nem faz questão de argumentar com consistência em favor da versão dos fatos que apresenta. E, ao mesmo tempo, como dito acima, suas incursões pelo relato histórico prejudicam o andamento do relato de viagem. Ou seja, pode-se dizer que as Cartas de França e Itália, por tal característica híbrida quanto ao gênero literário em que se enquadram, perdem sua força em ambas as frentes - História e relato de viagem.

Sobra intacta, no entanto, a política, que é a verdadeira protagonista deste texto de Herzen, à qual ele submete todas as demais disciplinas. Se as Cartas de França e Itália não são perfeitamente nem relato de viagem, nem relato histórico, nem ensaio jornalístico, é porque são, fundamentalmente, a profissão da fé revolucionária de Herzen, para cujos fins ele convoca o potencial retórico de quantas disciplinas e gêneros literários the parecem úteis. O quanto há de desilusão na apreciação que o autor-viajante faz dos eventos de 1848 há de firmeza expectante quanto ao futuro: pelo bem ou pelo mal, pelo socialismo ou pelo comunismo ${ }^{54}$, a revolução se haverá de fazer.

\footnotetext{
54 A palavra "comunismo" tem para Herzen um sentido em geral negativo, remetendo à opressão das individualidades pela igualdade massificante. Já "socialismo", termo de uso mais amplo, costuma caracterizar, no discurso do autor, a revolução autêntica por meio da qual a justiça social será estabelecida sem prejudicar as liberdades individuais. No entanto, ao fim das Cartas, como veremos, a desilusão levará Herzen a esperar por uma "onda comunista" a ser deflagrada pelos proletários e camponeses em revolta contra a ordem vigente e que varrerá do mapa a sociedade burguesa. Não é a revolução ideal, mas Herzen a prevê com um misto de esperança desesperada e repugnância. Cf. seção 2.3.6, abaixo.
} 


\subsection{Notas de Inverno Sobre Impressões de Verão}

Quando Dostoiévski decidiu fazer sua primeira viagem à Europa, em 1862, Vriêmia e o Potchviennitchestvo já haviam conquistado um considerável público na Rússia. A boa situação financeira da revista possibilitava a execução deste que era há tempos um sonho do escritor, segundo suas próprias palavras em carta ao poeta Ya. A. Polônski:

Quantas vezes, desde a minha infância, não sonhei que estava na Itália. Desde os romances de Anne Radcliffe, que li com oito anos de idade, todas as espécies de Catarinas, Alfonsos e Lucias têm povoado minha mente. Quanto aos Don Pedros e Doña Claras, ainda hoje falo deles com entusiasmo. Depois, veio Shakespeare - Verona, Romeu e Julieta - só o diabo sabe quanta mágica havia naquela terra! Itália! Itália! mas, em vez da Itália, caí em Semipalatinsk, e antes disso na casa dos mortos. Será que não conseguirei ir à Europa enquanto ainda tenho força, paixão e poesia? Será possível que só poderei ir lá daqui a uns dez anos, aquecer meus velhos ossos atacados de reumatismo e assar minha cabeça careca ao sol meridional $?^{55}$

Ele não precisaria esperar dez anos: em 7 de junho de 1862, menos de um ano após escrever essas linhas a Polônski, Dostoiévski embarcaria em sua primeira jornada ao Ocidente. Ele parte sozinho, dando às autoridades a justificativa de ir consultar-se com especialistas em sua condição de epilético ${ }^{56}$. Durante o mês de julho, encontra-se com seu amigo pótchviennik

\footnotetext{
${ }^{55}$ Pisma, vol. 1, p. 302; 31 de julho de 1861. Apud Joseph Frank, Os efeitos da libertação, p. 258.

${ }^{56}$ É comum se confundir essa primeira viagem de Dostoiévski à Europa com a que ele faria no ano seguinte para encontrar, em Paris, sua amante Apollinária Súslova. Embora essa segunda jornada também tenha sido muito importante à maturação intelectual do escritor (principalmente por ter sido a ocasião em que ele leu pela primeira vez as obras dos eslavófilos, com os quais até então só tivera contato indireto - Cf. Frank, op. cit. p. 379), a viagem que deu origem a Notas de Inverno Sobre Impressões de Verão foi a realizada em 1862, portanto sem conexão com o affair entre o escritor e a jovem Polina.
} 
Nikolai Strákhov na Suíça, e com Herzen em Londres ${ }^{57}$; e em setembro já retorna a Petersburgo. Uma jornada consideravelmente breve, mas para Dostoiévski foi mais do que suficiente para inspirar alguns comentários muito perspicazes sobre "a terra das santas maravilhas."

Pode-se dizer que as Notas de Inverno Sobre Impressões de Verão estão para o relato de viagem tradicional como a literatura de James Joyce está para a de Homero: é uma obra pensada para desconstruir a forma fixa do gênero a que se reporta, o que não pode ser feito através do alheamento da tradição, mas, pelo contrário, assimilando-a, verdadeiramente sequestrando-a para fazê-la servir a propósitos que antes lhe eram alheios. Assim, Dostoiévski escreve o relato de uma viagem ao estrangeiro cujo objetivo último é discutir questões internas do seu país de origem; a visita à Europa lhe serve senão como instrumento para repensar a Rússia. E isto se torna ainda mais significativo quando percebemos que tal atitude é uma alegoria das ideias políticas do autor, para quem era chegada a hora de a Rússia, amalgamando o legado político e cultural do Ocidente a seu próprio elemento nacional, emergir ao palco da História, substituindo os escombros do Velho Mundo.

É um relato motivado por uma viagem que de fato aconteceu, ou seja, há a experiência verídica do primeiro encontro entre o autor e o Ocidente motivando as Notas de Inverno. Porém, a presença do pendor artístico de Dostoiévski expressa-se na obra em muitas marcas de manipulação ficcional; reconhecemos em seu narrador-viajante, por exemplo, a mesma autoironia, o mesmo mau humor, o mesmo sarcasmo cortante e inclusive a mesma doença do fígado de que sofre o Homem do Subsolo, a cujas Memórias Dostoiévski daria forma pouco tempo depois - entre outros aspectos de ficcionalidade que discutiremos adiante. Assim, por mais que, em certa medida, seja possível basear-se nas Notas de Inverno para depreender alguns

\footnotetext{
${ }^{57}$ Cf. próxima seção.
} 
aspectos do primeiro encontro do Dostoiévski biográfico com a Europa, não é o caso de tomá-las por uma descrição literal ${ }^{58}$.

O relato de viagem dostoievskiano é, no mesmo sentido em que o de Herzen, um antirelato de viagem, mas em Dostoiévski a subversão do modelo tradicional é radicalizada, pois o grand tour europeizante não é aqui apenas descaracterizado, mas torna-se inclusive motivo de chacota. Nesse sentido, é curioso notar que as Notas de Inverno, exteriormente, aparentam-se mais ao relato de viagem tradicional do que as Cartas de Herzen. Este, como vimos, em longos trechos distancia-se do papel de viajante; já Dostoiévski nunca perde de vista a forma do relato de viagem, mas subverte-a por dentro, dando a suas apontamentos a aparência de um travelogue, para que tão mais forte seja o efeito de desconstrução.

Uma primeira grande diferença entre os relatos de viagem de Herzen e Dostoiévski é, portanto, esta: o primeiro propõe-se sinceramente escrever cartas descrevendo sua experiência europeia, dentro de um gênero literário bem estabelecido, e afasta-se do modelo tradicional eventualmente, sem premeditação; o segundo satiriza a tradição, Herzen inclusive, de caso pensado e com objetivos literários e retóricos específicos. Nunca passou pela cabeça de Dostoiévski escrever um relato de viagem tradicional.

O relato de Dostoiévski é estritamente literário, no sentido de que nele forma e conteúdo refletem-se poeticamente. Já apontamos que o sequestro de um gênero literário europeu para finalidades russas pode ser lido como alegoria do messianismo nacionalista de Dostoiévski, mas há ainda muitas outras relações desse tipo ao longo da obra. Dostoiévski, por exemplo, afirmava que os russos, ainda que educados segundo a cultura europeia, nunca eram capazes de se desfazer completamente de sua alma nacional:

\footnotetext{
${ }^{58}$ Curiosamente, é bem isto o que Joseph Frank faz, no capítulo de sua biografia de Dostoiévski o qual discute este momento da vida do escritor. Ao mesmo tempo, o biógrafo reconhece nas Notas de Inverno a obra onde Dostoiévski prepara o salto de originalidade que dará a partir de Memórias do Subsolo.
} 
Toda a nossa vida se dispôs em moldes europeus, já desde a primeira infância. Será possível que algum de nós tenha podido resistir a esta influência, a este apelo, a esta pressão? Como foi que ainda não nos transformamos definitivamente em europeus? Creio que todos concordarão que ainda não nos transformamos - o que, em uns, despertará alegria, e em outros, naturalmente, rancor por não estarmos suficientemente crescidos para a transformação. (...) Existirá realmente uma associação química, entre o espírito humano e o solo pátrio, que torne impossível a alguém separar-se definitivamente deste, e de modo tal que, se dele se separa, acaba sempre por voltar?"

Acontece que tais considerações são feitas no segundo capítulo das Notas, intitulado "No Trem", capítulo que deveria descrever a chegada do narrador à França; porém, ao invés de discutir a "terra das santas maravilhas", sua atenção continua fincada na Rússia, exatamente como, segundo Dostoiévski, a alma do russo educado reluta em tornar-se plenamente europeia. O título "No Trem" sugere indeterminação geográfica, a localização fronteiriça que é análoga à cisão do russo entre Oriente e Ocidente. De fato, as Notas de Inverno estão sempre nessa posição fronteiriça, pois mesmo quando o narrador descreve sua visita ao coração da Europa (à França, à Alemanha, à Inglaterra) sua atenção continua voltada à Rússia.

As Notas são confessadamente redigidas a posteriori, quando o autor já se encontra de volta à sua pátria; inclusive, em vários momentos ele interrompe a narrativa para consultar seu “caderno de notas", o que dá à obra um teor metalinguístico bastante raro no século XIX. Assim, logo no primeiro capítulo ele anuncia que "nada viu em ordem" e, se chegou a vê-lo, "não teve tempo de examiná-lo”. A jornada que nos promete será recontada a partir de esparsas anotações de viagem, além de sua memória inevitavelmente falha, e tudo mediado por uma sinceridade da

\footnotetext{
${ }^{59}$ Notas de Inverno, p. 79-80.
} 
qual o narrador não nos dá garantias, contra a qual, aliás, nos adverte. Ele nos declara que de início planejou "ver absolutamente tudo", de forma panorâmica, mas depois acabou arrependido por não ter visto nada em detalhes - o que é um modo de representar a relação dos russos com a cultura ocidental e, segundo nos diz Dostoiévski mais adiante, com novidades de modo geral. Ao fim e ao cabo, resta ao narrador reconstituir seu encontro com a Europa a partir de impressões fragmentárias e desordenadas, e orientado por sentimentos extremados que vão desde a reverência até o patriotismo ferido - pois tal é a relação de todos os russos com "a terra das santas maravilhas": caótica, superficial e, sobretudo, emocional.

Se o "nicho" do Herzen viajante era o de turista revolucionário, o do narrador de Dostoiévski será o de fornecer "observações pessoais, sem rigor nem exatidão", tagarelice e esboços ligeiros, pois, segundo o bordão que inevitavelmente abre os relatos de viagem russos, “o que há para dizer de novo sobre a Europa, que ainda não tenha sido contado?”. É claro que esse tom despretensioso é mera fachada: sob sua aparência de leveza, as Notas de Inverno abordam alguns dos temas mais polêmicos que marcaram a trajetória intelectual de Dostoiévski. Ele usará o conhecimento prévio que seus compatriotas têm do Ocidente para justificar seu tom largamente pessoal, e sob uma superfície de autoironia e comicidade reafirmará o programa pótchviennik defendido em Vriêmia.

Nas Notas de Inverno, com efeito, a realidade é inteiramente submetida à personalidade do narrador. Isto é dizer que não devemos de modo algum esperar uma descrição objetiva dos lugares e pessoas que são (em teoria) o assunto do relato, mas, pelo contrário, encontraremos sempre descrições subjetivas. Dostoiévski, afinal de contas, era um especialista em indivíduos, em sujeitos nos quais ele identificava traços exemplares da cultura de seu tempo. O sujeito para Dostoiévski é sempre um indivíduo diante de uma ação ou circunstância pela qual ele é 
moralmente responsável. Ou seja, são indivíduos que nunca podem ser reduzidos a meros produtos de seu meio, sendo agentes em constante diálogo com seus arredores. Esse princípio, discernível com mais clareza nos grandes romances, aparece já nas Notas de Inverno por meio da simbiose entre o meio ambiente e a consciência do narrador, que se deixa modificar por ele na mesma medida em que o modifica.

O trecho a seguir serve de exemplo a tudo o que foi dito acima:

- Ah! - exclamo. - Então, vocês precisam da simples tagarelice, de esboços ligeiros, impressões pessoais, colhidas em pleno voo. Concordo com isso e vou consultar já o meu caderno de notas. Procurarei ser ingênuo na medida do possível. Peço apenas lembrar que, possivelmente, haverá muitos erros no que eu vou escrever agora. Naturalmente, nem tudo estará errado. Não podemos enganar-nos, por exemplo, em fatos tais como a existência em Paris da catedral de Notre-Dame e do Bal Mabille. Este segundo fato, particularmente, foi em tal grau testemunhado por todos os russos que escreveram sobre Paris que não se pode quase duvidar dele. É provável, pois, que também eu não me engane nisto, mas, a rigor, não posso assegurar. $^{60}$

Note-se que, se assim parecer ao narrador, ele pode afirmar que a catedral de NotreDame não existe. Isto atesta o quanto a realidade retratada nas Notas é subordinada à consciência do sujeito que as narra, ao mesmo tempo em que este afirma sua independência em relação a tudo o que foi dito sobre a Europa por viajantes anteriores. Com efeito, à época da viagem de Dostoiévski já havia muitos fatos estabelecidos, no imaginário dos russos, sobre a realidade

${ }^{60}$ p. 75. 
ocidental; ele, porém, ao invés de crer maquinalmente nesses fatos, assume uma atitude como que cartesiana e decide ver tudo pela primeira vez.

No entanto, a Europa vista - ou, talvez mais apropriadamente, imaginada - por Dostoiévski só chegará até nós por meio de fragmentos, num jogo de expectativas e frustrações criadas pelo narrador. Ele seguidas vezes promete levar-nos até Paris, mas acaba sempre falando sobre a Rússia, ou sobre Londres, ou sobre o que quer que seja, contanto que não cumpra o que prometeu. Emblematicamente, o segundo capítulo inicia-se com a citação de uma frase de Fonvízin sobre os franceses, mas em vez de glosar sobre o conteúdo da frase o narrador se volta ao autor russo que a proferiu, tomando-a como ocasião para analisar a relação dos russos com os europeus. E, ao fim do mesmo capítulo, sob a desculpa de ter-se entediado porque estava "no trem” (sabemos que ele já está de volta à Rússia quando escreve), decide que o leitor também deve entediar-se, numa tirada comicamente misantropa - "É preciso afastar outros leitores" -, e declara que o próximo capítulo será "inteiramente supérfluo"; o capítulo em questão, porém, vem a ser um dos mais importantes do livro.

O caráter metalinguístico fica ainda por conta de intervenções de opositores imaginários (nova semelhança com Memórias do Subsolo), os quais acusam as contradições e promessas não cumpridas do narrador, evidenciando o fato de que para Dostoiévski é mesmo fundamental explicitar a artificialidade de seu relato de viagem. Recuperando uma imagem utilizada em $O s$ Demônios, podemos dizer que Dostoiévski deixa propositalmente à mostra alguns pontos em sua costura. Afinal, o narrador de seu relato é um personagem e é através de suas particularidades qualidades, defeitos, contradições - que o autor construirá o sentido da obra. Dizendo de outro modo: o sentido da obra não reside apenas em certos comentários feitos acerca do continente 
europeu, mas principalmente em tais comentários serem feitos desde o ponto de vista de determinado tipo de indivíduo.

É deste modo que o narrador dostoievskiano adquire a característica de camaleão que nos salta aos olhos: seu caráter não é fixo, mas varia de acordo com a necessidade do autor de expressar determinada ideia. Às vezes ele encarna o turista russo médio, meio deslumbrado, meio patriota, por meio do qual o autor critica seus conterrâneos viajantes, às vezes ele é o razoável observador por cuja voz fala o próprio Dostoiévski, e assim por diante, dependendo da necessidade do autor. Mas um dado é constante na personalidade desse narrador-turista: ele é russo, e é um russo de seu tempo. Ele personifica, com os vários matizes que adquire por meio da pena do autor, a relação da Rússia de meados do século XIX com a Europa burguesa do mesmo período. 


\section{Capítulo 2. Olhares cruzados}

\subsection{Antigas relações}

Em artigo de 1873, o segundo publicado no estreante Diário de Um Escritor, Dostoiévski relembra a "gente antiga" com quem convivera antes de sua prisão e exílio - gente como Herzen e Bielínski. Este artigo nos será muito útil como introdução ao paralelo entre Notas de Inverno e Cartas de França e Itália, não apenas porque nele estão sintetizados os principais pontos de discordância entre Dostoiévski e Herzen, mas sobretudo por ser uma síntese feita pelo próprio Dostoiévski. É preciso, contudo, ter em mente que o romancista de 1873, gozando já de um lugar cativo entre as letras de seu país, difere consideravelmente do aspirante a escritor que visitou Herzen na Inglaterra, em 1862, para elogiar com entusiasmo seu Da Outra Margem; e não difere apenas quanto a sua autoestima de escritor, mas também, e principalmente, no que diz respeito à radicalização de seus pontos de vista eslavófilos. Assim sendo, a importância deste artigo não é tanto ilustrar “a opinião de Dostoiévski sobre Herzen”, pois esta tem nuances diversas ao longo do tempo; o principal é que ele tangencia os pontos de contato fulcrais entre os dois autores, sejam por semelhança ou diferença, ao mesmo tempo em que nos permite acompanhar a evolução eslavófila do pótchviennik Dostoiévski em função da figura de Herzen.

Veja-se abaixo, na íntegra, o cerne do artigo:

Herzen era um produto de nossa aristocracia, gentilhomme russe et citoyen du monde sobretudo, um tipo que surgiu apenas na Rússia e apenas na Rússia poderia surgir. Herzen não emigrou e não abriu caminho para outros émigres russos; não, ele simplesmente nasceu um emigré. Todos eles, toda essa gente como ele, simplesmente nasceram émigres, ainda que 
a maioria nunca tenha saído da Rússia. No período de cento de cinquenta anos de vida da aristocracia russa que precedeu Herzen, as últimas raízes apodreceram e os últimos elos com a verdade e o solo russos afrouxaram-se, com apenas algumas exceções. A própria História parecia predestinar Herzen a ser sua mais vívida ilustração de como a maior parte das nossas classes educadas apartou-se do povo. Nesse sentido Herzen é um tipo histórico.

Quando romperam com o povo, eles naturalmente perderam Deus também. Os enérgicos entre eles tornaram-se ateus; os apáticos e sossegados tornaram-se indiferentes. Eles tinham somente desprezo pelo povo russo, ao mesmo tempo em que acreditavam amá-lo e querer o melhor para ele. Eles amavam o povo negativamente, imaginando em seu lugar algum tipo de ideal, um povo russo como ele deveria ser segundo o concebiam os intelectuais. Esse povo ideal, por um processo involuntário [na mente da intelligentsia], tomou a forma da multidão parisiense de 1793. Este era o ideal de povo mais sedutor naquele momento.

Herzen, é claro, tinha de tornar-se um socialista e fazê-lo exatamente ao modo de um jovem nobre russo, isto é, sem qualquer necessidade ou propósito, mas apenas pela "progressão lógica das ideias" e pelo vazio que sentia em seu coração quando estava na Rússia. Ele renunciou às fundações mesmas da antiga sociedade; ele negou a família e era, ao que parece, um bom pai e marido. Ele negou a propriedade privada, mas, enquanto a nova ordem não vinha, cuidou de sua situação apropriadamente e alegrava-se por ter independência financeira no estrangeiro. Ele trabalhou para fomentar revoluções e incitou outros a elas, e ao mesmo tempo amava o conforto e a paz familiar. (...) Certamente, era um homem incomum; mas o que quer que ele fosse - quer escrevesse suas memórias ou publicasse uma revista com Proudhon ou saísse às barricadas em Paris, quer sofresse ou se alegrasse ou duvidasse (...) ele era sempre, em todo lugar, ao longo de toda a sua vida e sobretudo um gentilhomme russe et citoyen du monde, simplesmente um produto do velho sistema de servidão o qual ele 
odiava e do qual emergiu, não apenas por nascimento mas por sua própria ruptura com sua terra natal e os ideais que a infundem. ${ }^{61}$

O que Dostoiévski faz neste artigo é identificar Herzen à sua categoria de personagens internamente cindidos - Raskólnikov, o Homem do Subsolo, Ivan Karamázov, Versílov e tantos outros. São tipos históricos, pois que produtos de uma conjuntura sociocultural determinada, daí que "já tenham nascido émigres", isto é, fadados a desenvolver-se alheados da realidade do solo russo. Tendo perdido o elo com a verdade nacional, perderam Deus - pois, para o Dostoiévski maduro, a verdade nacional russa coincide perfeitamente com o Cristianismo ortodoxo do narod. Mas, como em cada homem a fonte que emana a nacionalidade não se extingue, esses russos espiritualmente expatriados também intuíam a necessidade de contato com o povo, porém sem conseguir de fato tocá-lo, pois viviam fora da realidade russa fundamental - a Ortodoxia. Assim, desprezando no povo aquilo que o povo fundamentalmente era, os intelectuais cindidos entre sua alma russa e a "progressão lógica das ideias" só conseguiam amar o povo concebendo-o à imagem de um ideal distorcido - o ideal da massa revolucionária.

Herzen, para Dostoiévski, era o exemplo perfeito desse tipo de intelectual raskólnik, pois na esfera pessoal levava uma vida tranquilamente conservadora, ao mesmo tempo em que se sentia impelido a incitar a revolta contra a ordem de que era expoente. As Cartas de França e Itália, que Dostoiévski conhecia bem, são consistentes com essa leitura. A relação de Herzen com a revolução política e social expressou sempre a agonia do homem-bomba, que quer viver para a História mas sofre ao ter de destruir-se por tal causa.

\footnotetext{
${ }^{61}$ In: Dostoevsky, Fyodor. A Writer's Diary. Vol. 1 - 1873-1876. “Old People”. Trad. Kenneth Lantz. Northwestern University Press: 1994, pp. 126-127.
} 
Há, portanto, alguns grandes temas unindo os dois escritores, os quais nos servirão como

fio condutor da comparação aqui proposta. É possível classificar tais temas em dois grupos: 1) Legado Ocidental, onde será discutida a porção "negativa" da relação Rússia-Ocidente segundo os dois autores, abordando desde suas críticas ao status quo burguês até, no caso de Herzen segundo Dostoiévski, aspectos de seu pensamento diretamente influenciados pela filosofia europeia; 2) Ascensão da Estrela do Oriente, onde serão analisadas as esperanças messiânicas que ambos nutriam para o futuro da Rússia, baseadas em sua convicção de que a civilização ocidental estava em irrefreável declínio. A dupla frente de atuação de Herzen em seus primeiros anos na Europa (por um lado, analisando a situação europeia, por outro, analisando e divulgando a Rússia) é também discernível no caso de Dostoiévski. Em verdade, trata-se apenas do fato de que pensar a Rússia oitocentista não podia prescindir de reflexões concomitantes sobre a Europa.

Passaremos agora ao texto dos relatos de viagem, para verificar qual a leitura feita por Herzen da relação Rússia-Ocidente e no que consiste a releitura crítica proposta por Dostoiévski.

\subsection{Legado Ocidental}

\subsubsection{O deplorável burguês}

Do século XX até os dias atuais, tornou-se banal a polarização capitalismo x socialismo: quem reza pela cartilha de um rejeita a do outro e vice-versa. Porém, na Rússia do século XIX e no século XIX em geral - a malha ideológica tinha outra disposição. Dostoiévski, por exemplo, era antissocialista e anticapitalista a um só tempo, e ambos pelos mesmos motivos fundamentais. 
Sua crítica às capitais industriais da Europa - Londres e Paris - assemelha-se em muito à feita por Herzen e os pensadores da esquerda. O burguês endinheirado e hipócrita, pilar sobre o qual se sustentava o abjeto status quo europeu, é o inimigo comum entre os dois autores-viajantes aqui comparados. Ambos cruzarão a fronteira europeia para confirmar suas suspeitas russas de que o futuro já não pertence à "terra das santas maravilhas": tudo ali está infectado pelo comodismo burguês e imerso numa entropia autofágica.

É assim que a análise do caráter do burguês parisiense será um dos carros-chefes tanto das Notas de Inverno quanto das Cartas de França e Itália. Consumando a semelhança, ambas as análises partem de considerações sobre o teatro francês. Herzen justifica: "Os teatros são sustentados por aqueles que pagam mais; (...) a rica burguesia paga por tudo, e o teatro expressa as necessidades e interesses da classe média."62 Tanto ele quanto Dostoiévski interpretam o teatro como o "suborno de consciência" da burguesia francesa, a qual ama sobretudo sua estabilidade e lucro material, mas faz-se representar com heroísmo e nobreza sobre os palcos para se reconciliar consigo mesma:

No teatro, é indispensável apresentar-lhe [ao burguês] pessoas indiferentes ao dinheiro. Gustave deve brilhar unicamente de nobreza, e o burguês chora enternecido. Não pode sequer dormir tranquilo sem a indescritível nobreza. E quanto ao fato de ter cobrado doze mil francos em lugar de mil e quinhentos, isso até constitui sua obrigação: cobrou-os por virtude. ${ }^{63}$

Herzen, segundo seu método típico, imiscui a análise de situações concretas (apresentações teatrais a que assistiu em Paris) com reflexões de cunho histórico:

\footnotetext{
${ }^{62}$ Cartas, p. 27-28.
}

${ }^{63}$ Notas, p. 128. 
A burguesia surgiu nos palcos de forma brilhante na pessoa do astuto barbeiro e mordomo que resplendia como champanhe, em uma palavra, na pessoa de Fígaro. Mas agora está no palco na forma do industrial sensível, protetor dos pobres e defensor dos oprimidos. (...) O que os dois Fígaros têm em comum é basicamente apenas o fato de serem lacaios, porém sob o libré do primeiro Fígaro vê-se um homem, enquanto por baixo da sobrecasaca preta do novo Fígaro vê-se um libré. (...)

Herdeiro da brilhante nobreza e das brutas plebes, o burguês uniu em si os piores defeitos de ambas as classes e perdeu suas qualidades. Ele é rico como um duque, porém mesquinho como um varejista. (...) [A burguesia não possui] religião social alguma, então teve de pensar para si uma moralidade baseada na aritmética, no poder do dinheiro e no amor pela ordem. ${ }^{64}$

Dostoiévski também nota que "a condição de lacaio penetra cada vez mais a natureza do burguês, e cada vez mais se considera uma virtude" ${ }^{95}$, e ratifica o comentário de Herzen sobre a ganância como "religião social":

Acumular fortuna e ter o maior número possível de objetos transformou-se no principal código de moralidade no catecismo parisiense. Isto já existia antes, mas agora, agora isso tem certo ar por assim dizer sagrado. (...) Atualmente, é preciso juntar o dinheirinho e adquirir o maior número possível de objetos, e então pode-se esperar por algum apreço. De outro modo, é impossível contar não só com a consideração alheia, mas até com a autoconsideração. ${ }^{66}$

\footnotetext{
${ }^{64}$ Cartas, p. 29-30.

${ }^{65}$ Notas, p. 137.

${ }^{66}$ Notas, p. 126.
} 
A hipocrisia do burguês vem à tona ainda no vaudeville, que é "tanto uma criação nacional dos franceses quanto o idealismo transcendental é para os alemães" (Herzen) ${ }^{67}$, sendo “a única obra de arte quase impossível de transplantar para qualquer outro solo, e que pode viver unicamente no lugar em que nasceu, Paris." (Dostoiévski) ${ }^{68}$ No vaudeville o burguês expressa sua obscenidade e baixeza, cotidianamente escondidas sob uma aparência de virtude. Mas nesse caso o teatro não basta como válvula de escape: é imprescindível ao burguês viver também na realidade o seu vaudeville particular, contanto que nunca, de forma alguma se manche sua nobreza exterior:

Eis por que o burguês cobre os buraquinhos das botas com tinta de escrever, contanto que, pelo amor de Deus, não se note alguma coisa! E as épouses comem bombonzinhos, calçam seus gants, exibem os pezinhos e erguem com extrema graça os vestidos nos bulevares. O que mais se precisa para uma felicidade completa? Eis por que são impossíveis já os títulos de romance como, por exemplo, A Mulher, $O$ Marido e o Amante, pois os amantes não existem nem podem existir. E mesmo que existam em Paris na mesma quantidade que as areias do mar, apesar de tudo não existem e nem podem existir, porque assim foi decidido e firmado, porque tudo reluz de virtude. ${ }^{69}$

Na leitura de Dostoiévski, a ânsia do burguês por manter uma aparência de satisfação e virtude entrega sua insegurança. Ele sabe, no fundo, que sua posição é instável e que não poderá para sempre empurrar as grandes questões ao seu redor para baixo do tapete - ele sabe que uma classe sem ideais e valores para além de sua própria estabilidade material é insustentável a longo prazo. Herzen concorda:

\footnotetext{
${ }^{67}$ Cartas, p. 32.

${ }^{68}$ Notas, p. 159.

${ }^{69}$ Notas, p. 125.
} 
A burguesia não abrirá mão de nenhum de seus monopólios e privilégios. Ela tem uma religião - a propriedade, com todas as suas consequências romano-feudais. Aqui há fanatismo e lucro juntos, aqui há limitação e egoísmo, aqui há ganância e amor familiar ao mesmo tempo.

O sorriso de desdém não é uma novidade na história, ele esconde não apenas presunção e limitação estúpidas, mas também medo, uma consciência impura, uma insuficiência de argumentos racionais, e mesmo o reconhecimento do poder daquele de quem se ri. Este é o sorriso dos patrícios romanos aos nazarenos, dos cardeais romanos aos protestantes, de Napoleão aos ideólogos; é o sorriso dos nobres quando a burguesia demandava para si aqueles direitos que agora recusa ao povo. ${ }^{70}$

O burguês teme por sua estabilidade - mas teme quem ou o quê exatamente? Aqui estamos em um ponto da argumentação aparentemente propício à divergência entre Herzen e Dostoiévski, e no entanto também nisso ambos concordam: o burguês teme os socialistas.

Mas essa gente [os socialistas], em seu tempo, fracassou de uma vez [provável referência a 1848], e o burguês, no íntimo, despreza-a profundamente; despreza-a e, no entanto, apesar de tudo, tem medo. Sim, é justamente dessa gente que ele tem medo até hoje. Mas temê-la por quê? Bem que o Abade de Sieyès predisse em seu famoso panfleto que o burguês é tudo. "O que é o Tiers État? Nada. O que deve ser? Tudo.” Pois bem, aconteceu justamente como ele disse. Somente estas palavras, de todas as que se disseram então [1789], é que se realizaram; foram também as únicas a permanecer. E o burguês, apesar disso, parece

\footnotetext{
${ }^{70}$ Cartas, p. 58.
} 
não acreditar até hoje que tudo o que foi dito após as palavras de Sieyès desapareceu, desfezse qual bolha de sabão. ${ }^{71}$

Ou seja, o burguês - "vira-casaca" da Revolução Francesa - teme aqueles que ainda insistem nos dizeres daquela época ("liberdade, igualdade, fraternidade”). Para Dostoiévski, era fato que os ideais de 1789 já se tinham desfeito qual bolha de sabão, mas ao burguês era impossível convencer-se de que não tinha por que temê-los. E os temia justamente por tê-los traído, como explica Herzen:

Assim que ascendeu ao topo que a Revolução de 1830 preparara e as Leis de Setembro asseguraram, a classe média esqueceu seu passado, esqueceu mesmo a honra nacional e seus próprios direitos. (...) Até a Restauração o burguês ainda não vendera tudo o tinha em seu coração; ele ainda era respeitado; mas desde que se tornou possível converter todos os seus interesses em moedas tilintando e sua vida tornou-se um meio para acumular dinheiro, o povo passou a odiá-lo, quanto mais próximo fosse o contato que tivesse com ele. ${ }^{72}$

Dostoiévski, portanto, reconhece tanto quanto Herzen a força de que a ideia socialista dispunha naquele momento, ao ponto de fazer o burguês temer por sua segurança. Mas este é o limite final da concordância entre os dois autores. O que torna a argumentação de Dostoiévski mais esquisita, se comparada à de Herzen, é seu contínuo recurso à frustração de expectativas: só com algum esforço o leitor consegue compreender para onde está sendo conduzido. Enquanto o texto de Herzen é plano e direto, com a crítica à burguesia casando perfeitamente com a exaltação do socialismo, em Dostoiévski se parte da crítica à burguesia, passa-se pelo medo desta

\footnotetext{
${ }^{71}$ Notas, p. 130.

${ }^{72}$ Cartas, p. 209.
} 
aos socialistas e então, com apenas uma vaga explicação sobre o que motivaria tal medo, cai-se no cerne da crítica dostoievskiana ao socialismo-formigueiro, com a subsequente exposição da utopia pótchviennik-eslavófila sobre a sociedade organicamente fraterna ${ }^{73}$. Só após todo esse rodeio - que é, na verdade, o cerne do capítulo - o narrador retorna à insegurança da burguesia, para encerrar a questão sem ter-se aprofundado nela:

O burguês prospera, paga terrivelmente caro por essa prosperidade e a tudo teme, justamente por ter alcançado tudo. Quando se alcança tudo, torna-se penoso tudo perder. Disto se conclui diretamente, meus amigos: quem mais teme é aquele que mais prospera. ${ }^{74}$

Um modo de interpretar essa característica enviesada do discurso dostoievskiano é admiti-la como parte do que poderíamos chamar de estética da sugestão: Dostoiévski nunca diz diretamente o que pensa, mas prefere deixar que as entrelinhas de seus textos falem. No presente caso, a quebra de expectativa está no fato de o leitor ser levado a antipatizar a burguesia e, portanto, dispor-se a simpatizar com seus opositores mais aparentes (os socialistas), mas ser então tomado de assalto pela longa digressão antissocialista do narrador. O que se faz nas entrelinhas desse jogo narrativo é vacinar o leitor contra a sedução socialista: o mundo burguês é mau e abjeto, sim, e há em circulação uma ideia que se propõe combatê-lo e inclusive já se faz temer por ele - mas trata-se de uma falsa solução. Ou seja, Dostoiévski percorre, até certo ponto, o mesmo caminho de Herzen - do fracasso burguês à novidade socialista - para então voltar-se contra ele frontalmente.

Vejamos isto mais de perto.

\footnotetext{
${ }^{73}$ Este trecho das Notas de Inverno será analisado na seção [3.x.x]

${ }^{74}$ Notas, p. 136.
} 


\subsubsection{Socialismo: escravidão ou liberdade?}

Já vimos que Herzen embarcou para a Europa buscando a participação histórica que na Rússia the era impossível. As primeiras três cartas intituladas "da Avenida Marigny" nos dão apenas o preâmbulo desse sonho cuja concretização frustraria as expectativas do viajante. Nessas

três primeiras cartas temos o que mais se aproxima de um relato de viagem tradicional nas Cartas de França e Itália, com comentários sobre teatro, sobre turistas russos no estrangeiro, sobre as diferentes paisagens entre fronteiras e a qualidade da viagem pelas estradas de ferro. A partir da quarta carta, no entanto, o tom e o teor do texto mudam, pois mudam-se as circunstâncias: começa a tomar forma o torvelinho que desembocará nos acontecimentos de 1848 na Europa. E, com ele, começa a tortuosa trajetória que levará Herzen de uma empolgação "teórica e livresca" (em suas próprias palavras) pelo potencial político do Ocidente à afirmação de que em verdade era chegada a hora de despontar a Estrela Oriental.

As Cartas de França e Itália nos dão um desenho preciso desse processo, embora seja salutar reforçar o já mencionado fato de que os escritos de Herzen com frequência se contradizem ao longo do tempo, e às vezes mesmo dentro de um curto período. Ainda assim, sempre é possível remeter suas opiniões pontuais às circunstâncias imediatas que as produziram, buscando deste modo os mecanismos do pensamento do autor.

Quanto à questão do socialismo, em momentos diversos Herzen afirmou as mais diferentes posições, desde a mais sóbria progressão gradual das instituições sociais até a inevitabilidade da destruição de tudo o que pertencesse ao "velho mundo". Ele nunca abraçou por muito tempo um programa socialista inteiro e concreto - e este é um dos motivos de seu perpétuo alheamento dentro dos movimentos revolucionários russo e europeu. Ele era 
efusivamente partidário de causas pontuais, sempre ligadas à liberdade do indivíduo, e em geral tendia a associar a luta por tais causas aos levantes políticos de massa, mas jamais teve a iniciativa de liderar tais levantes. Herzen era um intelectual, não um ativista. Seus escritos mais emocionados e entusiásticos dizem respeito à sua participação, como testemunha ocular, de grandes comoções populares - mas só até o ponto em que a passeata pacífica ainda não virara praça de guerra.

Seus primeiros comentários francamente políticos nas Cartas têm um tom moderado, semelhante ao que empregaria muitos anos depois no diálogo com Bakúnin. Ao contrário do que se poderia esperar de um recém-chegado émigré, Herzen analisa a atmosfera política europeia pré-1848 com menos êxtase do que cautela:

Todos estão insatisfeitos com a situação atual da França, menos a inveterada burguesia, e mesmo ela está com medo de olhar à sua frente. Muitos sabem o que os descontenta, quase ninguém sabe os meios e o método para corrigi-lo, nem mesmo os socialistas, gente com um ideal distante que mal se pode ver no futuro. (...)

A acusação mais frequentemente repetida, e com razão, é que há algum tempo os interesses materiais suplantaram todos os outros; que as ideias, as palavras, as quais tão recentemente moviam os indivíduos e as massas, impelindo-os a deixar suas casas e famílias para pegar em armas e sair em defesa do que acreditavam ser sagrado, perderam sua força magnética e são agora repetidos por mero hábito ou civilidade. (...) Se antes havia discussões sobre os direitos inalienáveis do homem, sobre políticas de estado e patriotismo, hoje as pessoas estão ocupadas somente com a economia política. ${ }^{75}$ (Grifo meu)

\footnotetext{
${ }^{75}$ Cartas, p. 51-52.
} 
A rigor, há contraditoriedade mesmo entre estes pequenos trechos. Herzen primeiro critica os ideais longínquos dos socialistas e sua inexistente metodologia de ação, para logo abaixo colocar um pé atrás também quanto à ênfase exagerada em questões econômicas, dissociadas dos valores e ideais a que devem, por princípio, corresponder. Esse tipo de análise globalmente discordante e ao mesmo tempo simpatizante incondicional da causa revolucionária em abstrato ocorre com frequência nos escritos de Herzen de seus primeiros meses de exílio, quando os eventos marcantes de 1848 ainda estavam em preparação. No entanto, uma vez que tais eventos começam a eclodir, Herzen se inebria de sua atmosfera, e então podemos vê-lo tomado do mesmo furor revolucionário evidente nas cartas a Samárin:

4 de março. Mais eventos acumulam-se a cada dia, tornam-se mais enérgicos e importantes; o pulso intensificado da história bate fervorosamente, e visões e sentimentos pessoais perdem-se em meio à grandeza do que está acontecendo. (...)

20 de abril. Tempos notáveis. Minha mão treme enquanto tomo o papel, a cada dia há algo inesperado, algum estrépito de trovão; ou estamos diante de uma brilhante ressurreição, ou do dia do julgamento. Novas forças agitam-se na alma, velhas esperanças ressuscitam e uma prontidão viril para tudo é mais uma vez predominante. ${ }^{76}$

Note-se, porém, que estas palavras foram escritas na Itália, para onde a família Herzen mudara-se em novembro de 1847. Eles retornariam a Paris apenas em 5 de maio de 1848, para ver de perto a revolução. E, como costuma ser o caso com Herzen, a proximidade do conflito concreto modificaria consideravelmente sua apreciação dos eventos.

\footnotetext{
${ }^{76}$ Cartas, p. $111-112$.
} 
A décima carta, datada de 10 de junho de 1848, já introduz o tema da decepção revolucionária nas Cartas de França e Itália. "Mais uma vez a raiva e a indignação enchem a alma... Estávamos errados, fomos enganados. É difícil reconhecer isto aos trinta e cinco anos de idade",77, diz Herzen no parágrafo de abertura. No entanto, entre "estávamos errados" e "fomos enganados", o restante da carta tratará de fundamentar esta segunda opção. Afinal, a república instaurada na França não passara de uma mascarada burguesa - o que é, mesmo em nossos dias, o mais frequente comentário aos fiascos socialistas: "não era socialismo de verdade". Herzen considera que o povo francês não estava pronto para o sufrágio universal ${ }^{78}$, mas essa é a única ressalva teórica feita à instauração da nova república, o único ponto no qual ele concede que a revolução "estava errada" em seus fundamentos. De resto, sua análise do verdadeiro motivo do fracasso baseia-se na "infiltração burguesa" entre os socialistas franceses:

A bandeira da República passada, que se tornou um império, a bandeira de Napoleão, uma bandeira que ofendeu a toda a Europa (...), foi aceita como pendão da nova república. A nova república se declarou burguesa, não rompeu com o passado e, consequentemente, teve de confrontar a república esperada [socialista], e confrontá-la com mais malícia do que usara contra a monarquia, pois entre a monarquia e o socialismo ainda havia precisamente a república formal, política. Assim que a burguesia soube das três cores, as lojas reabriram e seu coração estava apaziguado. Em retorno a essa concessão, ela fez, de sua parte, outra tão significativa quanto - concordou com reconhecer a república! $!^{79}$

Ou seja, o burguês tranquilizou-se ao perceber que a república socialista fora neutralizada e que ele continuaria a reinar sob as três cores da nova república. O problema da revolução

\footnotetext{
${ }^{77}$ Cartas, p. 120.

${ }^{78}$ Cartas, p. 148.

${ }^{79}$ Cartas, p. 139.
} 
francesa de 1848 fora, portanto, o burguês - ou ao menos a análise de Herzen desvia para ele toda ou quase toda a sua atenção. Herzen passa a acusar "espírito burguês" mesmo nos socialistas franceses e a apontar sua incapacidade "cultural" para a revolução, ao mesmo tempo em que se aproxima da ideia de que o movimento revolucionário continuará gastando munição e forças à toa enquanto não destruir completamente as raízes do velho mundo:

A questão é muito simples; a ideia revolucionária do nosso tempo é incompatível com o a estrutura do Estado europeu. (...) As pessoas normalmente pensam que o socialismo tem como seu único objetivo a resolução da questão do capital (...). Este não é absolutamente o caso. Questões econômicas são de extrema importância, mas constituem apenas um lado de toda uma visão de mundo que luta para aniquilar, junto com o abuso da propriedade, tudo o que é monárquico e religioso - na corte, no governo, em toda a organização social e, sobretudo, na família, na vida privada, nas condutas e na moralidade. ${ }^{80}$ (Grifo meu)

Aqui entramos no cerne da discordância entre Dostoiévski e Herzen. Este, fascinado com a França revolucionária de 1789, frustra-se com a curta vida da república fundada neste mesmo país diante de seus olhos e decide que a utopia socialista só será possível após uma transfiguração total do mundo ao seu redor, transfiguração essa que, para chegar a questões estritamente políticas, deve partir da base moral e comportamental da sociedade. Dostoiévski entende o significado desta ideia e reconhece-a como a pedra-de-toque da mentalidade socialista; ele é um dos primeiros (senão o primeiro) pensadores a perceber que o socialismo teórico demandaria, na prática, uma transformação essencial do homem, com a criação de um novo e, por assim dizer, um super-homem. E ele rejeita o socialismo justamente na medida em que

\footnotetext{
${ }^{80}$ Cartas, p. 164.
} 
rejeita a ideia da deificação do ser humano revoltado contra sua filiação divina. Este problema é abordado no seguinte diálogo entre Kiríllov e o narrador de Os Demônios:

- O homem de agora ainda não é o homem correto. Vai haver um novo homem, feliz e orgulhoso. (...) Aquele que triunfar sobre a dor e o medo tornar-se-á ele mesmo Deus. E então haverá uma nova vida, um novo homem, um novo tudo... Então a história dividir-se-á em duas partes: do gorila à destruição de Deus e da destruição de Deus...

- Ao gorila?

- ...à mudança física da terra e do homem. E o mundo mudará, e as ações mudarão, e os pensamentos, e os sentimentos. ${ }^{81}$

Dostoiévski estava convicto de que, rejeitando a ideia de Deus, a humanidade fatalmente regrediria à bestialidade. Essa é uma discussão recorrente no Diário de um escritor:

Não há homem ou nação que possa viver sem uma "ideia superior", e há apenas uma ideia deste tipo na terra, aquela de uma alma humana imortal; todas as demais "ideias superiores" advêm desta. (...) Após a perda da ideia de imortalidade, o suicídio aparece como uma necessidade completa e inelutável para qualquer homem que estiver minimamente acima do nível das bestas selvagens. (...) A ideia de imortalidade é a própria vida, a formulação definitiva e a primeira fonte de verdade e integridade para a consciência humana. ${ }^{82}$

Nikolai Berdiáiev, comentando esta passagem em seu livro sobre Dostoiévski, dá-lhe a seguinte interpretação:

\footnotetext{
${ }^{81}$ In: Demons, trad. Richard Pevear e Larissa Volokhonski, Vintage Books: Londres, p. 116.

${ }^{82}$ A Writer's Diary - vol. 2. Trad. Kenneth Lantz. Northwestern University Press: 1994, p. 1317.
} 
O valor absoluto do homem advém do fato de ele ser uma criatura imortal, não podendo, portanto, ser utilizado como meio ou instrumento para a realização de um "interesse" qualquer. Ou o homem é um espírito imortal com um destino eterno, ou é apenas um fenômeno empírico e efêmero, o produto passivo de seu meio ambiente natural e social. Se esta última opção for o caso, ele não tem valor intrínseco e o mal e o pecado não existem. $^{83}$

Ou seja, Dostoiévski percebeu que a mentalidade socialista, concebendo o homem como um mero fenômeno empírico, produto de seu ambiente natural e social, não hesitaria em usá-lo como instrumento para a construção de sua utopia histórica; os fins justificam os meios, ainda que tais meios sejam vidas humanas, desde que se subtraia ao homem sua dignidade transcendente ${ }^{84}$.

Nas Notas de Inverno, a reflexão sobre o socialismo enquanto reino dos super-homens parricidas é introduzida a partir de comentários sobre a Revolução Francesa. E neste ponto a discordância com Herzen é total. "A grande revolução de 1789” é o contraponto pelo qual Herzen denuncia o que entende como a farsa dos eventos de 1848:

Sequer posso descrever a vocês os sentimentos dolorosos que me possuíram quando olhei para o mundo ao meu redor. Nós estávamos acostumados a associar a palavra "Paris" às memórias dos grandes eventos, das grandes massas, do grande povo de 1789-93; às memórias do embate colossal pelo pensamento, pelos direitos, pela dignidade humana - um embate que permeava praças públicas, campos de batalha e discussões parlamentares. O nome de Paris está intimamente ligado a todas as melhores esperanças do homem contemporâneo. Eu cheguei aqui com meu coração batendo timidamente, como antes as pessoas chegavam a

\footnotetext{
${ }^{83}$ BERDIÁlEV, N. Dostoevsky. Meridian Books: 1968, p. 105-106.

${ }^{84}$ Esta ideia será melhor explorada nas seções a seguir.
} 
Jerusalém ou a Roma. E o que encontrei - a Paris descrita nos Iambes de Barbier, no romance de Sue, e nada mais [i.e., a Paris burguesa]. ${ }^{85}$

Herzen não mede esforços para aproximar 1848 a 1789 e, quando já não é possível fazêlo numa chave otimista, o faz para mostrar o quanto esta mais recente tentativa revolucionária deixou a desejar se comparada a sua antecessora gloriosa. Já Dostoiévski, para quem ambas as datas marcaram capítulos da história de Prometeu tentando roubar o fogo dos céus, analisa o lema da Revolução de 89 para concluir que, de tudo o que foi dito então, nada restou:

O que é liberté? A liberdade. Que liberdade? A liberdade, igual para todos, de fazer o que bem se entender, dentro dos limites da lei. Mas quando é que se pode fazer o que bem se entender? Quando se possui um milhão. (...) O homem desprovido de um milhão não é aquele que faz o que bem entende, mas aquele com quem fazem o que bem entendem. O que se conclui daí? Conclui-se que, além da liberdade, existe a igualdade e justamente a igualdade perante a lei. Quanto a esta, pode-se dizer apenas que, na forma em que ela se pratica atualmente, cada francês pode e deve considerá-la como uma ofensa pessoal. O que subsiste, pois, da fórmula? A fraternidade. Ora, este ponto é o mais curioso e, deve-se confessar, constitui no Ocidente, até hoje, a principal pedra de toque. O ocidental refere-se a ela como a grande força que move os homens, e não percebe que não há de onde tirá-la, se ela não existe na realidade. O que fazer, portanto? É preciso criar a fraternidade, custe o que custar. ${ }^{86}$

O socialismo, para Dostoiévski, é uma tentativa de se criar a fraternidade à força, adaptando o fracassado lema da Revolução Francesa e transformando-o em "liberté, egalité,

\footnotetext{
${ }^{85}$ Cartas, p. 128.

${ }^{86}$ Notas, p. $130-131$.
} 
fraternité ou la mort ${ }^{\gg 7}$. Esta mesma ideia é desenvolvida muitos anos após as Notas de Inverno, no Diário de um escritor, em um dos últimos artigos jornalísticos escritos por Dostoiévski, no qual ele desejava expressar sua "profissão de fé", ${ }^{\circ 8}$. De fato, muitas das ideias que nas obras estritamente literárias são tratadas sob o que aqui chamamos de estética da sugestão ganham, neste artigo, uma explanação minuciosa. É o caso da afirmação de que uma sociedade na qual se extinguiu a "ideia superior” que a originara está fadada à dissolução:

Todas as vezes em que a ideia moral-religiosa na qual se sustentava uma nacionalidade desgastou-se, teve origem uma urgência covarde e atemorizada por "salvar a própria pele" - não há outros objetivos para a união cívica nesses casos. Tome-se o exemplo da burguesia francesa hoje, a qual se une por esse mesmo propósito de "salvar sua pele" do quarto estado que está tentando derrubar sua porta. Mas "salvar a própria pele" é a ideia mais fraca, é a última de todas as ideias que podem unir a humanidade. Este já é o começo do fim, um pressentimento do fim. (...) Se houvesse irmãos, então haveria fraternidade. Se não há irmãos, então você não alcançará a fraternidade por meio de alguma "instituição" [p.ex., uma república]. Qual o sentido em estabelecer uma instituição e inscrever nela: Liberté, égalité, fraternité? Nada se alcançará aqui por meio de uma "instituição", então será inescapavelmente necessário acrescentar a essas três palavras "institucionais" uma quarta: ou la mort, fraternité ou la mort - e então irmão cortará a cabeça de irmão para que se possa estabelecer a fraternidade por meio desta "instituição cívica" ${ }^{89}$

\footnotetext{
${ }^{87}$ Notas, p. 135.

${ }^{88}$ Retornaremos a este artigo mais adiante.

${ }^{89}$ Diary of a writer, vol. 2, p. 1319.
} 
Nas Notas de Inverno, apesar de referir-se a 1789 como "pequenas traquinagens, aquelas do fim do século passado" $"$, dizendo ainda que os franceses "brincaram um pouco e voltaram ao espírito que anteriormente dominava"91 ${ }^{91}$ Dostoiévski sabe que o socialismo é coisa séria: ele sabe que o mundo está desorganizado o suficiente, que há bastante sofrimento pelas ruas para que a ideia do formigueiro de super-homens frutifique entre os povos, expulsando Deus de seus corações.

Nesse sentido, as Notas são uma crítica abrangente ao mundo ocidental sob duas perspectivas: a que enfoca o burguês francês, ganancioso, mundano e mesquinho, e a que revela a natureza do profundo mal que há sob a aparência de ordem sustentada por este mesmo burguês, mal este que vem à tona com toda a força na capital inglesa. Na França, diz Dostoiévski, as aparências realmente enganam e tudo parece reluzir de virtude (embora baste levantar a pontinha do tapete do burguês para descobrir-lhe a sujeira); já na Inglaterra o mal é uma fratura exposta. Por isso, quando quer mostrar a própria raiz maligna da vida ocidental, o narrador dostoievskiano volta-se a Londres:

Esta cidade que se afana dia e noite, imensurável como o mar, com o uivar e ranger de máquinas, estas linhas férreas erguidas por cima das casas, esta ousadia de iniciativa, esta aparente desordem, que em essência é a ordem burguesa no mais alto grau, este envenenado Tâmisa, este ar impregnado de carvão de pedra, (...) A City, com os seus milhões e o seu comércio mundial, o Palácio de Cristal, a Exposição Internacional... Sim, a exposição é impressionante. Sente-se uma força terrível, que uniu num só rebanho todos estes homens inumeráveis, vindos do mundo inteiro; tem-se consciência de um pensamento titânico; sentese que algo já foi alcançado aí, que há nisso uma vitória, triunfo. (...) “Não será este realmente

\footnotetext{
${ }^{90}$ Notas, p. 143.

${ }^{91}$ Idem.
} 
o ideal atingido?”, pensa-se, “Não será o fim? Não será este, de fato, o 'rebanho único'?” Não será preciso considerá-lo como a verdade absoluta e calar para sempre? (...) Isto constitui não sei que cena bíblica, algo sobre a Babilônia, uma profecia do Apocalipse que se realiza aos nossos olhos. Sente-se a necessidade de muita resistência espiritual e muita negação para não ceder, não se submeter à impressão, não se inclinar ante o fato e não deificar Baal, isto é, não aceitar o existente como sendo o ideal... ${ }^{92}$

Herzen não gosta do burguês porque este oprime os proletários e financia uma ordem política contrária à liberdade e à prosperidade para todos. Dostoiévski não gosta do burguês por acreditar que ele personifica o culto a Baal, o demônio do mundo e da carne, e a perda da dimensão transcendente na percepção que os homens têm de si mesmos e do mundo. "Aceitar o existente como sendo o ideal" quer dizer abdicar do ideal sobrenatural prometido pela revelação judaico-cristã e presumir a possibilidade humana de construí-lo por aqui mesmo, neste teatro menor $^{93}$. E, embora o capitalismo burguês e o socialismo sejam fenômenos intelectuais e sociais diversos, ambos, para Dostoiévski, são formas de se reduzir o ideal ao existente, de se desdivinizar o divino para engendrar o super-homem parricida. Ambas também são formas de se seduzir a humanidade por meio da saciedade material:

Está claro que é muito atraente viver em bases puramente racionais, mesmo que não seja de fraternidade, quer dizer, é bom quando garantem a você tudo, exigindo em troca apenas trabalho e concórdia. Mas nisso aparece novamente um problema: o homem fica, ao que parece, completamente garantido, prometem dar-lhe de comer e de beber, proporcionar-

\footnotetext{
${ }^{92}$ Notas, p. 113-114.

${ }^{93}$ Cf., entre inúmeros exemplos da literatura madura de Dostoiévski, a seguinte fala de Piotr Verkhoviénski em Os Demônios: "Uma lei nova e justa está a caminho, o mar ferverá e a casa de espetáculos virá abaixo, e então nós veremos como se constrói um edifício de pedra. Nós construiremos o edifício, nós, nós sozinhos!" - onde o "edifício de pedra" é uma clara referência à Igreja Cristã edificada sobre o apóstolo Pedro. In: Demons, op. cit., p. 422.
} 
lhe trabalho e, em troca, exigem-lhe apenas uma partícula de sua liberdade individual, em prol do bem comum. Mas não, o homem não quer viver segundo estes cálculos. (...) Naturalmente, resta ao socialista apenas cuspir e dizer-lhe que é um imbecil, que não cresceu suficientemente; que uma formiga é mais inteligente do que ele, pois no formigueiro tudo é tão bom, todos estão alimentados e felizes (...), numa palavra: o homem ainda está longe do formigueiro! $!^{94}$

Não há dúvidas de que aqui já ouvimos a voz do Homem do Subsolo. De fato, as Notas de Inverno marcam o início da tentativa dostoievskiana de resolver o grande problema de sua obra madura, qual seja, "a luta tenaz e antiga, a luta de morte do princípio pessoal com a necessidade de instalar-se num formigueiro comum."95 Não se trata apenas da crítica a um modelo de sociedade ou a um tipo de pensamento político, mas ao deslocamento do homem de seu eixo existencial, com a perda da consciência de sua imortalidade, o que para Dostoiévski tem consequências desastrosas, sobretudo se erigido em um modelo político de escala nacional ou global. "O Grande Inquisidor", capítulo mais enigmático de Os Irmãos Karamázov, é a culminância poética dessa reflexão dostoievskiana.

Assim, embora Dostoiévski, como Herzen, odiasse o mundo burguês, era motivado por preocupações que sequer entravam no horizonte de problemas do turista revolucionário. Herzen abraçava o socialismo por um genuíno sentimento humanitário e cria sinceramente na solução socialista como oposta à realidade do mundo burguês. Para Dostoiévski, pelo contrário, socialismo e capitalismo industrial eram faces da mesma moeda ${ }^{96}$, expoentes da mesma

\footnotetext{
${ }^{94}$ Notas, p. 135.

${ }^{95}$ Notas, p. 112.

${ }^{96}$ Nikolai Berdiáiev, pensador educado na escola dostoievskiana, reitera essa ideia: "A intenção do socialismo não é substituir o capitalismo, pois são ambos feitos da mesma carne e sangue e cobrem o mesmo terreno. $O$ socialismo quer, sim, substituir o Cristianismo, pois é ele mesmo repleto de espírito messiânico e afirma ser o
} 
tendência moderna a se encerrar a existência humana neste mundo e negar sua dimensão metafísica. A principal diferença entre ambos é que o status quo burguês era um fato, enquanto o socialismo ainda era uma promessa, e uma promessa que entrava pela porta dos fundos do Cristianismo, cujo reino final de paz e prosperidade teimava em não vir. Trata-se das mesmas tentações feitas pelo demônio a Cristo no deserto e retomadas pelo Grande Inquisidor: se apenas Cristo tivesse optado por satisfazer a humanidade, transformando pedras em pão e curando milagrosamente todas as suas chagas, não haveria o gancho da angústia pelo qual o Inquisidor (e os socialistas, e os capitalistas do Palácio de Cristal) roubarem o rebanho humano de sob as asas da verdadeira Igreja cristã: pois nesta o crente vive uma dolorida espera por um reino que não sabe quando vem, embora o faça em liberdade, enquanto no formigueiro do Anticristo os homens abdicam de sua liberdade para anestesiar seu sofrimento e obter o pão deste mundo.

Vejamos agora se é possível, de fato, atribuir a Herzen o parricídio ontológico dos grandes heróis dostoievskianos.

\subsubsection{O problema da moralidade: a ética do egoísmo de Herzen}

Herzen está longe de ser o primeiro de sua estirpe de pensadores. Sua visão de mundo é um amálgama de noções iluministas e românticas: ele considerava a religião como o inimigo primordial na batalha pela dignidade do homem, ao mesmo tempo em que conferia à razão humana plenos poderes cognoscentes sobre a realidade. O corolário moral dessa visão de mundo é evidente: "Herzen afirmava que o homem inventa sua própria moralidade; que, animado por

portador de um evangelho da humanidade resgatada da miséria e do sofrimento". In: Dostoevsky, Meridian Books: 1968, p. 139. 
esse egoísmo sem o qual não há vitalidade nem atividade criativa, o homem é responsável por suas próprias escolhas e não pode recorrer ao álibi da natureza ou da história se falhar ao tentar concretizar aquilo que ele considera, por qualquer motivo que seja, bom, ou justo, ou prazeroso, ou belo, ou verdadeiro." 97

Tal concepção de moralidade, por sua vez, tem fortes implicações políticas:

Na monarquia, como na religião, não se pode falar em moralidade. A obediência, ao exilar a responsabilidade, exclui a moralidade ao mesmo tempo; a autoridade nega a dignidade e a autonomia humanas, assim como a crença nega o pensamento. Em uma monarquia apenas a pessoa do soberano é moral, uma vez que apenas ele é livre. (...)

A abolição da autoridade é o princípio da república. Sua condição primeira é um povo livre e autônomo; a autoridade mata a independência da razão. Uma república não necessita de outros princípios além daqueles necessários a qualquer comunidade; ela se baseia naquelas condições essenciais, universais e necessárias, sem as quais qualquer sociedade torna-se impossível. Estas são obrigatórias não porque os homens vivam em uma república, mas porque vivem juntos, porque é impossível racionalmente rejeitá-las. ${ }^{98}$

Este trecho condensa alguns problemas importantes da visão de mundo de Herzen. Primeiramente, a afirmação de que a obediência exclui a responsabilidade é um non sequitur: se A obedece a ordem de B para matar C, não tendo sofrido coação física, é responsável por esta morte, pois poderia ter desobedecido a ordem que recebeu. Do mesmo modo, na relação entre um crente e seu Deus, estabelecida em um nível profundamente subjetivo, a obediência resultará sempre da livre aceitação, pelo sujeito que crê, dos pressupostos das leis obedecidas. Isto é,

\footnotetext{
${ }_{97}^{97}$ BERLIN, Isaiah. Introdução a From the Other Shore and The Russian People and Socialism, p. XVI.

${ }^{98}$ Cartas, p. 165-166.
} 
mesmo o crente que siga as leis divinas pelo mais prosaico medo do inferno não se exime da responsabilidade pelos atos praticados em nome de sua crença, pois o próprio ato de crer, em sentido religioso, envolve vontade (volição) e implica diversas escolhas, comprometendo moralmente o sujeito que crê.

Em seguida, Herzen afirma a existência de "condições essenciais, universais e necessárias" à existência de qualquer sociedade, ao mesmo tempo em que não especifica no que estas consistem, tampouco entra no problema dificílimo da existência de valores universais em um universo fechado à metafísica ${ }^{99}$. De modo que sua ética resulta em um frágil compêndio de afirmações mais ou menos incompatíveis, por exemplo: cada homem é livre para definir sua noção de bem, embora haja certos princípios universais, inalienáveis e comuns a todos os homens (Herzen não nos diz se estes se restringem a "não matar" e "não roubar", ou se valem também para "não cobiçarás a mulher do próximo"), princípios estes dados na ordem da natureza, na razão humana (“é impossível racionalmente rejeitá-los”), porém nem a natureza nem a razão humana seguem qualquer ordem pré-determinada, não podendo servir como álibi para as escolhas humanas, portanto ( sic) cada homem é livre para definir sua noção de bem, etc.

Na ética de Herzen, quando os homens acreditam em si mesmos, em sua própria razão, instintos e consciência, eles tornam-se livres: "O princípio que regula a ação de um homem deve estar dentro dele, em sua própria razão; se estiver fora dele, ele é um escravo, não importa qual seja seu imenso valor" ${ }^{100}$. No entanto, segue inexplicado por qual lei de necessidade os homens libertos dos grilhões de uma moral exterior a si mesmos e fiéis exclusivamente a suas consciências e instintos serão capazes de engendrar o paraíso da justiça terrena, em vez da pura e simples anarquia. Herzen intui a necessidade de um padrão de conformidade aos instintos

\footnotetext{
${ }^{99}$ Para uma introdução de fôlego ao problema, v. Eric Voegelin, “On Debate and Existence”, ensaio disponível online em http://www.firstprinciplesjournal.com/articles.aspx?article=1181\&loc=fs $(11 / 01 / 14)$.

${ }^{100}$ HERZEN, A. My Past and Thoughts, p. 905.
} 
conflituosos dos homens, o que o faz afirmar a existência das mencionadas "condições necessárias às sociedades", mas não consegue conciliar esta intuição com o restante de seu sistema de princípios egoísta e imediatista. E é neste ponto de conflito entre intuição e racionalização que ele se aproxima dos heróis dostoievskianos.

Em suas antecipações de como seria o socialismo posto em prática (por exemplo, em $O s$ Demônios e em $O$ Grande Inquisidor), Dostoiévski definiu a igualdade socialista como um princípio nivelador em tudo oposto às verdadeiras justiça e liberdade. Excluído o parâmetro universal (o Logos Divino), e sendo impossível edificar qualquer edifício social sem algum eixo análogo a este ${ }^{101}$, resta à elite que preside a nova sociedade humana encontrar um novo modo de manter a ordem, o qual já não pode depender da livre consciência dos indivíduos (pois para haver harmonia entre consciências livres é necessário um parâmetro moral universal). Esta nova ordem é portanto estabelecida sobre uma igualdade massificante e aniquiladora de consciências:

Cada um pertence a todos e todos a cada um. Eles serão todos escravos e iguais em sua escravidão. Calúnia e assassinato em casos extremos, mas acima de tudo - igualdade. (...) Escravos devem ser iguais: jamais houve liberdade ou igualdade sem despotismo, mas em um rebanho sempre haverá igualdade. (...) Ouça, Stavróguin: nivelar as montanhas é uma ideia boa, não é ridícula. ${ }^{102}$

$* *$

Pois, quem iria dominar os homens senão aqueles que dominam suas consciências e detêm o seu pão em suas mãos? Nós tomamos a espada de César e, ao tomá-la, te renegamos,

\footnotetext{
101 O que se depreende das falas do próprio Herzen. Pela lógica de Dostoiévski, ao reconhecer as "leis universais da razão e da natureza", Herzen, sem percebê-lo ou admiti-lo, reconhecia Deus. Já as gerações radicais que viriam em seguida não teriam sequer o "escrúpulo" de julgar necessários alguns princípios fixos de moralidade, tendo portanto realmente perdido toda a intuição da transcendência, do bem universal. Herzen, também neste ponto, era um híbrido entre dois mundos.

${ }^{102}$ Fala de Piotr Verkhoviénski, in: Demons, op. cit., p. 418.
} 
é claro, e o seguimos. (...) Tu [Cristo] te orgulhas de teus eleitos, mas só tens eleitos, ao passo que nós damos tranquilidade a todos. Sob nosso domínio todos serão felizes e não mais se rebelarão nem exterminarão uns aos outros em toda a parte, como sob tua liberdade. Oh, nós os persuadiremos de que eles só se tornarão livres quando nos cederem sua liberdade e se colocarem sob nossa sujeição. (...) Oh, nós finalmente os persuadiremos a não se orgulharem, pois tu os encheste de orgulho e assim os ensinaste a ser orgulhosos; nós lhes demonstraremos que eles são fracos e que não passam de míseras crianças, mas que a felicidade infantil é mais doce do que qualquer outra. ${ }^{103}$

O modelo social idealizado por Herzen, de uma sociedade perfeitamente justa baseada no convívio entre consciências autossuficientes e autodeterminadas, era, para Dostoiévski, uma falácia teórica e uma impossibilidade prática. O pisado e repisado "Se Deus não existe, tudo é permitido" não significa que, para Dostoiévski, o ateu não pode ser moral; significa, antes, que toda moralidade advém do Logos Divino (tudo o que é racional, tudo o que é belo, tudo o que é bom o é à imagem de Deus; as leis da natureza são as leis da inteligência divina) e, portanto, o ateu moral não compreende a si mesmo: acredita criar seu próprio comportamento, quando na verdade apenas segue as intuições inscritas em sua natureza de criatura. Porém, uma vez que os homens se voltam contra essas intuições básicas, sobrepondo-lhes construtos teóricos e abstrações conceituais, caem no labirinto de Raskólnikov, o emblema dostoievskiano do homem que sabe que não deve matar, e no entanto mata para questionar e testar os limites do que sabe, sacrificando a realidade concreta a uma teoria.

Herzen foi uma espécie de Raskólnikov, com a diferença de que vitimou a si mesmo. A inconsistência de sua ética é flagrante já na incompatibilidade lógica de seus postulados

\footnotetext{
${ }^{103}$ Fala do Grande Inquisidor, in: Os Irmãos Karamázov, ed. 34, pp. 357-358.
} 
(exemplificada acima), mas, como se não bastasse, foi testada também na prática - e falhou. Sua biografia contém algumas notáveis (e trágicas) anedotas, exemplares da mesma contradição entre intuição e abstração conceitual à qual Dostoiévski deu vida com seus personagens. A mais famosa dessas anedotas diz respeito à "comuna pessoal” fundada pela família Herzen em companhia do poeta alemão Georg Herwegh, em 1850.

Estabelecer uma vida comum ao lado de seu irmão político Georg Herwegh representava um novo estágio na contínua metamorfose das esperanças de Herzen, após extinguir-se a última faísca de esperança de 1848. Mais realista do que os “bárbaros franceses”, capaz de reconhecer o despreparo das massas para a revolução e recusando-se a admitir a legitimidade de ações políticas baseadas num princípio de simples destruição da ordem vigente, sem previsão de algo melhor a ser construído no lugar, Herzen deixa o palco das ruas em busca de sua utopia pessoal. A "vida completa" exigia participação nos "interesses gerais" da humanidade, e isto ele faria por meio de sua atuação como escritor, ao mesmo tempo em que alcançaria, na esfera de sua vida particular, a harmonia, a beleza e a justiça, em suma, a plenitude da personalidade que, em sua concepção de uma sociedade ideal, deveria ser o princípio e o objetivo.

Ele então deixa Paris para exilar-se em Nice, em companhia de Herwegh, numa franca tentativa de "purificar-se" do caos ao seu redor:

Escolhi Nice não apenas por seu ar e seu mar agradáveis, mas também porque ela não tem significado - nem político, nem intelectual, nem mesmo artístico. É uma clausura pacífica na qual eu me exilo do mundo, até termos de novo necessidade um do outro. (...) 
Adentro tranquilamente este porto e desenharei o antigo pentagrama na soleira de minha casa para afastar qualquer espírito de angústia e loucura humana... ${ }^{104}$

Após o fiasco de 1848, Herwegh aparecera a Herzen como um dos poucos ocidentais a compartilhar de suas convicções políticas. O ensaio "A Rússia” (La Russie, escrito em francês em agosto de 1849), primeiro texto de Herzen sobre a Rússia escrito no Ocidente, é dedicado ao amigo alemão. Mas o que Herzen não previa era que a vida comunal ao lado de Herwegh não só não curaria a ferida de 1848 , como a aprofundaria. O Ocidente o desapontara na esfera política e agora, personificado por Herwegh, o desapontaria definitivamente na esfera pessoal.

A anedota tem um enredo antigo, mas sempre devastador: a noção herzeniana de moralidade autorreferente, que acabamos de discutir, seria testada na prática pela união extraconjugal de Herwegh com a esposa de Herzen, Natalie. Ferido pela evidência indiscutível de que o livre instinto de sua esposa a conduzira aos braços de outro homem, o qual, apesar de um vínculo de amizade e fraternidade, tivera o livre instinto de possuir a esposa do companheiro, Herzen, o apologeta do egoísmo irrestrito, não poderia jamais protestar contra tudo isso sem cair em franca contradição. E no entanto ele protestou ardentemente. Descoberta a infidelidade das duas pessoas que lhe eram mais próximas, ele lança-se em uma campanha para estabelecer uma "corte de honra" contra Herwegh, numa tentativa de lavar sua imagem pública manchada pelo ex-amigo. Em julho de 1852, faz divulgar um apelo endereçado a seus principais comparsas ocidentais - Proudhon, Mazzini, Willich, Wagner e Michelet -, dos quais esperava "um gesto de amizade" a seu favor:

${ }^{104}$ Cartas, 174 e 183. 
Para condenar e estigmatizar crimes que, por sua própria baixeza, escapam aos processos de nossos inimigos oficiais, eu me dirijo ao único tribunal que reconheço, um júri de correligionários, do qual espero justiça contra a infame ofensa que presentemente denuncio - uma sentença tão mais solene e terrível por ser executada pela consciência de homens de boa fé. Nossos irmãos democratas europeus, respondendo espontaneamente a meu apelo, unânimes em sua condenação, declararam-se prontos a amaldiçoar um homem que negligenciou a própria honra...

Que o veredito seja pronunciado e a justiça seja feita pela primeira vez sem advogados ou policiais, em nome da solidariedade dos povos e da autonomia dos indivíduos. $^{105}$

Mas tais palavras não tiveram grande eco entre seus destinatários, o que se afigurou a Herzen como um derradeiro golpe ocidental contra seu "ingênuo espírito russo".

É evidente que a noção de "honra pública" é incompatível com a cosmovisão cujo ideal social é um coletivo de consciências determinadas apenas por si mesmas. Afinal de contas, como vimos, "o princípio que regula a ação de um homem deve estar dentro dele, em sua própria razão; se estiver fora dele, ele é um escravo, não importa qual seja seu imenso valor"106 Herzen, implorando de joelhos à opinião pública europeia que defendesse sua honra conjugal, e convocando em favor de sua causa a "solidariedade dos povos e a autonomia dos indivíduos", poderia protagonizar uma das cenas tragicômicas dos romances dostoievskianos, como aquela em que o liberal "supérfluo" Stiepan Trofímovitch pega sua trouxinha e sai em sua derradeira caminhada rumo ao povo. São cenas dramáticas, de fundo melancólico, mas diante das quais o

${ }^{105}$ Sobrânie sotchiniêni v trídtsati tomákh. Moscou: Izdatel'stvo Akademii nauk SSSR, 1954-1965, tomo VII, p. 386387.

${ }^{106}$ HERZEN, A. My Past and Thoughts, p. 905. 
leitor não pode evitar um sorriso piedoso, pois retratam momentos em que certos indivíduos se desvelam em sua mais pura natureza confusa e contraditória.

Herzen percebia apenas parcialmente que algo estava errado em sua concepção de moralidade. Reconhecia com razão que, ao atacar o "velho mundo", atacava a si mesmo, o que acabou convencendo-o de que sua geração não estava mesmo destinada a ver consumada a nova ordem social e o novo homem, pois tinha raízes demasiado fincadas no solo tradicional: "Nós mesmos pertencemos em vida, hábitos e linguagem àquela esfera política e literário-acadêmica a qual repudiamos." ${ }^{107}$. Mas, ingênua e obstinadamente, atribuía sua tragédia particular ao fato de não se ter isolado do mundo o suficiente e ter intentado viver sua utopia em parceria com outro homem:

Eu não encontrei a paz que buscava, o porto seguro. (...) Por um longo tempo pensei que fosse possível, ao menos pessoalmente, começar uma nova vida, retrair-me em mim mesmo para longe da tagarelice pública. Isto não é possível - basta haver um só homem por perto com o qual não se rompam todos os vínculos, o velho mundo com todo o seu vício e devassidão, sua esperteza e perfídia, retornará por meio dele. ${ }^{108}$

Tais palavras deixam claro que Herzen não reconhece a conduta de Natalie e Herwegh como em perfeita conformidade com a ética hedonista partilhada por todos os integrantes da comuna de Nice. No entanto, o vício e a devassidão não eram, como ele queria crer, males do "velho mundo" infiltrados clandestinamente em seu paraíso particular, mas haviam sido cuidadosamente semeados e estimulados por quem agora lastimava seus amargos frutos. A prova

\footnotetext{
${ }^{107}$ Sobrânie sotchiniêni v trídtsati tomákh. Moscou: Izdatel'stvo Akademii nauk SSSR, 1954-1965, tomo V, p. 208. É uma das características mais marcantes do pensamento de Herzen construir generalizações a partir de sua experiência pessoal.

${ }^{108}$ Idem, tomo V, 201.
} 
cabal disso viria pouco tempo depois, em 1856, com a coroação do ciclo de bizarrices conjugais de Herzen: estabelecido em Londres, após a morte de Natalie, e morando com seu amigo de infância Nikolai Ogarióv, ele passa a relacionar-se com a esposa deste - também chamada Natalie! -, com a qual vem a ter três filhos, apesar de um relação conturbada e infeliz. Ao menos nisso Herzen estava mais em acordo com suas próprias ideias do que em sua campanha, anos antes, para conseguir a condenação pública de Georg Herwegh, seu gêmeo ocidental.

Esta anedota biográfica ilustra, quase com o peso de uma refutação, por que é falaciosa, na concepção de Dostoiévski, a ideia de uma sociedade pacífica e justa formada por homens que respondam apenas ao chamado de sua "moralidade interior". Herzen a tinha como base de seu pensamento político, mas em seu microcosmo pessoal tudo o que ela gerou foi anarquia seguida de antissociabilidade.

Este problema perpassa toda a obra de Dostoiévski, mas em Memórias do Subsolo ganha particular evidência. A eloquente argumentação do Homem do Subsolo em favor do "direito humano ao capricho" deve ser compreendida em dois níveis, um positivo e outro negativo. O sentido positivo é que a irresistível paixão da humanidade pela desordem, pelo caos e pelo sofrimento é senão produto e sintoma de sua inalienável liberdade, motivo pelo qual o homem resiste a ser transformado em mera "tecla de piano" ou habitante de formigueiro. Contudo, a liberdade mal direcionada pode transformar-se em capricho, em infantil intransigência, e este é o sentido negativo impresso no discurso do Homem do Subsolo. O ser humano é, de fato, livre e pode escolher ser e fazer o que quiser, mas isto não significa que todas as escolhas possíveis são corretas. O homem é livre dentro de um universo regido por leis que não só independem dele como também o incluem: a própria natureza humana funciona de acordo com a engrenagem universal, cujo "cérebro" é o Logos Divino. Assim, embora os homens sejam livres para escolher 
entre o bem e o mal, não está em seu poder confundir um com o outro e alterar a ordem da natureza.

Herzen, ao afirmar que há certos "princípios universais", os quais o homem não pode rejeitar sem ferir a própria racionalidade, intuía a mesma verdade referida por Dostoiévski em seus grandes romances. Mas há em Herzen, ao mesmo tempo, o capricho infantil do Homem do Subsolo - infantil pela obstinação em não se submeter senão a si próprio, como sói acontecer aos adolescentes. Porém, como a própria história pessoal de Herzen ilustra, o homem é incapaz de existir de modo autossuficiente. Se não tomar consciência de seu lugar no mundo, isto é, de sua submissão natural e inevitável a uma ordem que o transcende, consumir-se-á no esforço de rebelar-se, esforço que pode tomar proporções gigantescas e alcançar aparentes sucessos pontuais, mas nunca logrará produzir um estado de coisas em que os homens convivam sem precisar submeter-se a uma autoridade qualquer. A diferença, diz Dostoiévski, é que sob a autoridade divina há liberdade, mas sob a autoridade dos super-homens que propõem "corrigir a façanha" de Cristo há apenas escravidão justificada pela saciedade material - como se lê na fala do Grande Inquisidor, citada acima.

Até aqui, tratamos da parte negativa do pensamento dos dois autores, isto é, dos problemas para os quais buscavam solução - problemas cujo símbolo melhor acabado era o status quo burguês europeu. A seguir, abordaremos suas ideias positivas, as quais, nos dois casos, são indissociáveis do papel que ambos atribuíam à Rússia num futuro próximo. 


\subsection{Ascensão da Estrela do Oriente}

\subsubsection{A derradeira metamorfose de Herzen}

O traumático rompimento com seu mais íntimo comparsa ocidental tem sobre Herzen um efeito de gota d'água, piorado ainda pela morte precoce de Natalie, em 1852. Viúvo, traído e tendo tentado sem sucesso limpar sua honra manchada por Herwegh, sua sobrevivência então se sustenta sobre dois artifícios: a mudança para a Inglaterra em agosto daquele mesmo ano e o projeto de escrever suas memórias, o qual daria origem a Passado e Pensamentos, em cuja composição Herzen trabalharia pelos anos seguintes. De fato, é o próprio Herzen quem inicia a prática de expor seu pensamento à luz de suas experiências biográficas. Ele faz questão de infundir cada texto seu com sua poderosa presença. Ter vivenciado a revolução de 1848 mudou drasticamente o modo como ele entendia o assunto quando, ainda na Rússia, a perspectiva de um levante socialista na França lhe enchia de doces esperanças revolucionárias. Mas tal mudança de percepção foi sendo alcançada à medida que, por meio de textos, ele recontava para si mesmo aquela história. O diário e o relato de viagem são, assim, instrumentos cruciais à forma como Herzen desenvolvia suas ideias. Após cinco anos de decepções europeias, ele tinha agora muito sobre o que refletir e o que sistematizar e, principalmente, precisava reencontrar-se com sua própria identidade:

Para que você convoque o tribunal de seu próprio povo, precisa primeiro ter um povo seu. Onde estava o meu? (...) Eu tinha tido meu próprio povo outrora na Rússia. Mas agora estava tão completamente alheio em uma terra estrangeira; eu tinha a qualquer custo que me 
comunicar com meu próprio povo; queria compartilhar com eles o peso que trazia em meu coração... (...) E pouco a pouco comecei a trabalhar em meu Passado e Pensamentos. ${ }^{109}$

A mudança para a Inglaterra justifica-se, nesse contexto, como a alternativa "neutra" entre as principais nações europeias. França, Itália e Alemanha estavam demasiado ligadas à concepção de revolução de que Herzen, agora, desejava desvencilhar-se. Sua perspectiva era mais do que nunca aquela do intelectual ideólogo ou observador, em oposição ao ativista. Seu discurso podia ainda sustentar contradições internas, mas na prática ele aprendera a lição: colocar-se no centro da praça de guerra seria sinônimo de destruir-se, pois ele era, por dentro e por fora, um produto do "velho mundo", capaz de entusiasmar-se sinceramente com as novas ideias, mas não de tolerar sua reductio ad absurdum.

Em Londres, em fevereiro de 1853, Herzen fundará a Imprensa Russa Livre, que será sua trincheira de guerra pelos próximos doze anos, durante os quais ele conseguirá influenciar o debate político russo e inflamar discussões importantes, como a que precedeu a emancipação dos servos em 1861. Seu jornal Kólokol era amplamente lido. E foi durante esses anos que ele desenvolveu sua doutrina do Socialismo Russo.

Porém, já em 1849, no ensaio La Russie, dedicado a Georg Herwegh, encontram-se algumas das ideias que serviriam de base ao Socialismo Russo ${ }^{110}$. Não se pode, portanto, supor

\footnotetext{
${ }^{109}$ In: My Past and Thoughts: The Memoirs of Alexander Herzen. 4 Vols. Tr. by Constance Garnett, revised by Humphrey Higgens. London: Chatto and Windus, 1968, pp. 1023-6.

110 Por exemplo: "Cette année, Hasthausen l'employa à une étude approfondie de la commune rurale en Russie. Le résultat de ses recherches ne fut pas tout à fait semblable à celui de Custine. II dit, en effet, qu'en Russie, la commune rurale est tout. Là, suivant l'opinion du baron, est la clef du passé de la Russie et le germe de son avenir, la monade vivifiante de l'Etat russe. (...) Je partage entièrement l'opinion de Haxthausen; mais je crois qu'en Russie la commune rurale n'est pas tout non plus. II me semble qu'il y a dans la vie russe quelque chose de plus élevé que la commune et de plus fort que le pouvoir; ce quelque chose est difficile à exprimer pardes-mots, et plus difficile encore à indiquer du doigt. Je parle de cette force intime n'ayant pas entièrement conscience d'elle-même, qui tenait si merveilleusement le Peuple russe sous le joug des hordes mongoles et de la bureaucratie allemande, sous le knout oriental d'un Tartare et sous la verge occidentale d'un caporal; je parle de cette force intime, à l'aide de
} 
uma guinada brusca de um ocidentalismo inveterado a um nacionalismo cheio de orgulho ferido após as frustrações pessoais de Herzen. É certo que a derrota nos planos político e pessoal reforçou sua ênfase na Rússia a partir de 1852, mas é preciso considerar tal guinada como um processo ao longo dos anos, não como uma reversão brusca.

Que a frustração pessoal tomou parte nesse processo fica claro a partir do modo como Herzen passa generalizar o caráter dos europeus, claramente tomados segundo o modelo de Georg Herwegh, ao mesmo tempo em que tende a entender a relação entre russos e ocidentais como um embate entre "sangue jovem" e o "ocidente degenerado". Ele se torna defensivo em relação à Rússia e acidamente hostil à Europa; as críticas que já fazia ao establishment burguês ganham agora um pessoalismo quase carnal, e é eliminada a distinção entre revolucionários europeus "verdadeiros" e "incompletos" - todos, agora, são incompletos. A carta aberta a Jules Michelet, analisada mais adiante, é um dos primeiros produtos dessa necessidade de Herzen de afirmar-se, por meio da afirmação seu país, face ao que ele compreendia como a degeneração do Ocidente.

Seu discurso nesse período, e em escritos posteriores sobre esse período, descreve como sua natureza russa e sua vida familiar foram assaltadas pela "corrupção ocidental" (já discutimos a distorção implícita nessa ideia). Em Passado e Pensamentos, numa seção sobre sua tragédia pessoal, escrita em 1857, ele recorda um romance histórico chamado Arminius, que descreve os primeiros séculos do Cristianismo e a queda de Roma, e a colisão desses dois mundos com enfoque nos "destinos das pessoas que eram diretamente dependentes deles":

laquelle s'est conservée la physionomie ouverte et belle et la yive intelligence du paysan russe, malgré la discipline, avilissante du servage, et qui, au commandement impérial de se civiliser, a répondu, après un siècle, par la colossale apparition d'un Pouchkin." In: HERZEN (1849), La Russie. 
Nunca me passou pela cabeça que eu seria presa de uma colisão semelhante e que meu próprio lar seria esmagado pelo encontro de duas rodas da história mundial.

O que quer que seja dito aqui, papéis análogos a estes existem em nossas relações com os europeus. Nossa civilização é rasa, nossa depravação é brutal, nossos pêlos grosseiros eriçam-se sob o pó-de-arroz e as queimaduras de sol aparecem sob a cerusa; mas nós estamos também muito atrás quanto às sutilezas hereditárias e intangíveis da corrupção do Ocidente...

E é deste modo que nós sucumbimos facilmente a um homem que toca nossos maiores tesouros, que entende nossos pensamentos secretos, que tem coragem para dizer em voz alta o que nós deixaríamos passar em silêncio ou sussurraríamos ao ouvido de um amigo. Nós não consideramos que metade das falas que tocam nosso coração e nos deixam sem ar já se tornaram para a Europa truísmos e meras frases; nós esquecemos quantas muitas outras paixões corrompidas, paixões senis e artificiais, estão enraizadas na alma de um homem moderno que é fruto desta civilização exausta. ${ }^{111}$

Esse desapontamento generalizado com o Ocidente, se não foi a causa originária, foi o solo fértil de onde Herzen fez crescer o seu Socialismo Russo, cujo impacto sobre a intelligentsia russa na segunda metade do século XIX foi mais abrangente do que se pode supor à primeira vista. Dostoiévski sem dúvida bebeu das ideias de Herzen para formular o projeto pótchviennik de revitalização da cultura russa. Do mesmo modo, Herzen tem sido, e com razão, apontado como o pai do movimento populista dos anos 70, famoso por sua tentativa de "ida ao povo". Joseph Frank, ao discutir a posição ideológica de Dostoiévski após o período siberiano e a sensível tendência eslavófila que se propagara, ao longo dos anos 50, mesmo entre simpatizantes do Ocidentalismo, evoca o trabalho jornalístico e ensaístico de Herzen como principal fonte para a nova tendência:

\footnotetext{
${ }^{111}$ My Past and Thoughts, pp. 857-8.
} 
Essa nova síntese de ideias foi concebida e propagada em grande parte por Aleksandr Herzen, que havia passado a ocupar o lugar preponderante na cultura exercido por Bielínski nos anos 1840. (...) Herzen passou da negação à afirmação. O que agora afirmava contradizia fortemente suas crenças anteriores, pois ele vaticinava que a atrasada Rússia, justamente por ter permanecido alheia à principal corrente do desenvolvimento histórico e social da Europa, era o instrumento eleito pela história para liderar o mundo na nova era socialista. Adaptando algumas ideias dos eslavófilos e combinando-as com as dos ocidentalistas, Herzen criou um grandioso amálgama que inflamou a imaginação russa e influenciou de maneira decisiva os rumos do pensamento sociocultural do país durante todo o restante do século. ${ }^{112}$

\section{Andrzej Walicki explica no que consistia o amálgama entre Ocidentalismo e}

\section{Eslavofilismo, típico desta fase final da trajetória de Herzen:}

Dos eslavófilos, Herzen tirou a ideia da comuna aldeã como etapa embrionária de uma nova e mais elevada forma de sociedade, e a convicção de que o coletivismo (que chamava de 'elemento socialista', e até de 'comunismo') era uma característica nacional do povo russo. (...) Como os eslavófilos, Herzen ressaltou que o povo russo não fora afetado pelo legado da lei romana e das concepções individualistas, a ela associadas, das relações de propriedade. Como os eslavófilos, Herzen valorizou os princípios da autonomia das comunas e a espontaneidade natural das relações entre seus membros, que não se regiam por contratos ou códigos legais. Por último, tal como os eslavófilos, Herzen acreditava que, na Rússia, a fé ortodoxa era 'mais fiel aos ensinamentos dos Evangelhos do que o catolicismo', que o isolamento religioso havia permitido felizmente que o povo russo evitasse a desmoralização do catolicismo e permanecesse distante da civilização europeia 'enferma'. Graças a esse

\footnotetext{
${ }^{112}$ Os Anos de Provação - 1850 a 1859. Trad. Vera Pereira. São Paulo, Edusp: 1999, pp. 320-321.
} 
isolamento - ou seja, graças à Ortodoxia - o povo na Rússia tinha sido capaz de preservar sua comuna, (...) não recuara diante das autoridades e 'felizmente sobrevivera para testemunhar a emergência do socialismo na Europa." "113

Essa virada no pensamento de Herzen pode ser verificada em um ensaio muito importante, O Povo Russo e o Socialismo, escrito em 1851, no formato de uma carta aberta a Jules Michelet, o qual, em texto intitulado Polônia e Rússia: uma lenda de Kosciusko, jurara poder "provar que a Rússia não existe, que os russos não são humanos e são destituídos de qualquer senso moral." ${ }^{114}$ Herzen, em resposta à invectiva de Michelet, escreve um ensaio onde busca defender a honra do povo russo - do povo, não do governo ou da Rússia Oficial, como faz questão de enfatizar. Embora algumas das ideias aí expostas apareçam também nas Cartas de França e Itália, nestas ocorrem mais indiretamente, na esteira da crítica à burguesia ocidental. Como já observamos, os textos de Herzen que lidam diretamente com questões russas, nessa época, formam um bloco à parte dos que se ocupam da Europa. A plena compreensão das Cartas, deste modo, depende de buscarmos sua contraparte russo-nacionalista neste outro grupo de textos. É o que faremos em seguida.

\subsubsection{O Socialismo Russo de Herzen: revolucionário, porque socialista;}

\section{conservador, porque russo}

\footnotetext{
${ }^{113}$ Apud FRANK, Joseph. Os Anos de Provação - 1850 a 1859, pp. 321-322.

${ }^{114}$ Citado por Herzen, From the Other Shore \& The Russian People and Socialism, p. 165.
} 
No início da carta a Michelet, Herzen se posiciona como porta-voz do "pobre povo russo", o qual carece de quem o defenda frente às acusações do autor francês. Em seguida, anuncia que "o período mais difícil para o povo russo está chegando ao fim. Uma batalha terrível o espera. A grande questão, o ‘ser ou não ser’ da Rússia, será resolvida em breve.” E vaticina, ao mesmo tempo, que "a Europa se aproxima de um terrível cataclismo", com o fim do legado feudal da Idade Média. Não se deve, porém, creditar tal virada histórica ao movimento revolucionário responsável por 1848:

As revoluções religiosas e políticas estão se exaurindo sob o peso de sua própria e completa impotência. Elas já conquistaram muito, mas falharam em completar suas tarefas. Elas roubaram o prestígio de que Trono e Altar outrora gozavam, mas não estabeleceram a era da liberdade. Elas acenderam novos desejos nos corações dos homens, mas não lhes deram modos de satisfazê-los.

(...) A Europa está envolta na austera e espessa escuridão que deve preceder a batalha final. Não há vida, mas apenas suspense, angústia. Tudo está de pernas para o ar. (...) Desviando-se desse mundo a decompor-se e desfazer-se em pedaços, os olhos dos homens buscam involuntariamente o Oriente. Ali, qual obscura montanha despontando entre brumas, discernem-se os contornos ameaçadores e pouco amistosos de um império: ele parece avançar como uma avalanche - ou como uma manada impaciente, ansiosa por acelerar os últimos momentos, já prolongados demais, de seu benfeitor moribundo. ${ }^{115}$

As antigas bases da civilização europeia estão ruindo, há demasiadas contradições em um mesmo cenário e a implosão da velha ordem parece inevitável, assim como o banho de sangue que a há de coroar, pois não há no Ocidente (em sua cultura, em sua filosofia) um elemento

\footnotetext{
${ }^{115}$ From the Other Shore \& The Russian People and Socialism. Oxford UP: 1979, pp. 167-169.
} 
positivo, capaz de conciliar as forças conflitantes e impedir o cataclismo, menos ainda de nortear o que quer que se erija em lugar do continente devastado. A mentalidade europeia, para Herzen, àquele momento compunha-se de pura negação, ao passo em que a Rússia, pelo contrário, era uma potência recém-nascida, cheia de tesouros por explorar e com uma ideia nova em seu bojo, ideia essa capaz de jogar luz sobre o caos europeu. Um novo momento - o florescimento de uma ideia - iniciava-se como que naturalmente, dando sequência ao curso inexorável da História, e era a hora e a vez da Estrela do Oriente. Evidentemente, os europeus recusavam-se a reconhecêla como tal, mas isto, para Herzen e toda a sua geração de raskólniki intelligenty, era apenas mais uma evidência do destino messiânico da Rússia:

Pois era justamente assim que as pessoas naqueles dias, no marco inicial da revolução cristã e da vitória do barbarismo, falavam de Roma como se fosse imortal e da seita nazarena como um elemento lunático e desprezível. ${ }^{116}$

James Billington, em seu imprescindível O Ícone e O Machado, afirma sobre a geração de Herzen, profundamente influenciada pelo Romantismo alemão:

Todos os jovens idealistas viam o sofrimento e a humilhação da Rússia pela Europa durante o início do período moderno como um processo purificador que garantia à Rússia um papel redentor na nova era que se iniciava. Pregadores pietistas alemães e seus herdeiros filosóficos, Baader e Schelling, encorajavam os russos a acreditar que o ideal evangélico da Santa Aliança precisava manter-se vivo; que a Rússia deveria constituir uma nova força supra-política dedicada a curar as chagas espirituais da Europa. ${ }^{117}$

\footnotetext{
${ }^{116}$ P. 171.

${ }^{117}$ BILLINGTON, James. The Icon and the Axe: an interpretive history of Russian culture, p. 317.
} 
Ainda que a ênfase de Herzen não seja na continuidade da Santa Aliança (como no caso dos eslavófilos), há uma evidente adaptação do idealismo deísta ao socialismo tipicamente russo por ele professado. Seu pensamento é marcado pela tentativa de conciliar o primado da liberdade individual (e o pleno desenvolvimento da personalidade) com o messianismo nacionalista segundo o qual a Rússia seria a cabeça do exército eslavo que inauguraria um novo momento da História. Nas palavras de Isaiah Berlin:

Ele se persuadira de que as admiráveis qualidades russas seriam por si suficientes para resolver 'o maior problema do século' - aquele de como reconciliar o direito à liberdade individual com as demandas de uma autoridade inevitavelmente mais e mais centralizada; como preservar a vida pessoal sem 'atomizar' a sociedade, o dilema central que 'o mundo do Ocidente até agora não conseguiu resolver'. Produção coletivizada associada à preservação dos direitos e da liberdade de pessoas individuais - direitos e liberdades pelos quais nem Marx, nem Cabet, nem Louis Blanc haviam mostrado a menor simpatia -, eis a resposta com a qual o camponês russo impressionará o mundo. (...) Armado com as técnicas científicas ocidentais, o intacto mujique russo ensinará ao mundo uma grande lição de organização social. $^{118}$

Herzen prossegue seu diálogo com Michelet formulando o que seria "a mais genuína das questões":

Se supusermos que o mundo eslavo pode contar com o prospecto de uma forma de vida mais desenvolvida no futuro, então qual dos seus elementos seminais é o mais avançado,

\footnotetext{
${ }^{118}$ In: From the Other Shore \& Russian People and Socialism. "Introduction", p. XIX-XX.
} 
qual provê a melhor base para tamanhas esperanças? Se os eslavos estão certos em acreditar que sua hora chegou, então esse elemento deve necessariamente ser aquele que estiver em sintonia com as ideias revolucionárias na Europa. ${ }^{119}$

Isto é, se cabia aos eslavos dar continuidade à história que até então fora presidida pelo Ocidente, deveria haver uma conexão entre o presente europeu e a semente eslava que fecundaria o futuro dos povos. Esta semente, para Herzen, é o Comunismo - termo que na carta a Michelet tem conotação positiva, designando meramente o sistema de partilha comum da terra empregado pelos camponeses russos ${ }^{120}$. Aí residia o potencial dos povos eslavos, coincidindo perfeitamente com o principal problema a ocupar os intelectuais do Ocidente naquele momento: "não há nenhuma outra questão mais séria no século XIX do que o problema do comunismo e da divisão da terra." 121

Porém, antes de cantar loas à comuna camponesa de seu país, Herzen precisava responder às acusações de Michelet, segundo as quais “o russo é um inveterado mentiroso e ladrão: e o é inocentemente, pois é de sua natureza ser assim." ${ }^{, 22}$ Ele concorda parcialmente com tal afirmação, ao reconhecer a fraqueza moral do narod, mas a atribui a circunstâncias sociais negativas, isto é, nega que seja um traço essencial do caráter popular, senão uma contingência

\footnotetext{
${ }^{119}$ P. 177.

120 "A maior parte dos camponeses russos não eram fazendeiros cultivando sua própria terra, mas partícipes de comunas rurais que possuíam a terra coletivamente e a redistribuíam periodicamente para ajustar o lote de cada família a mudanças em seu tamanho. A terra, aos olhos dos camponeses, não era uma mercadoria, mas uma fonte de sustento a qual apenas aqueles que a cultivassem tinham o direito de reivindicar." In: PIPES, Richard. Communism: A History of the Intellectual Movement. Phoenix: 2003, p. 22.

${ }^{121}$ P. 177.

${ }^{122}$ Citado por Herzen, p. 180.
} 
inteiramente corrigível, e o principal: mesmo em tão negativas circunstâncias, o povo russo preserva intacto seu potencial para a vida comunitária.

Para Herzen, além de a imoralidade popular ser corrigível, é também razoavelmente justificável, uma vez que roubar e mentir eram a única defesa e, mais do que isso, o modo de expressão restante a um povo oprimido pela burocracia "alemã" do império russo. Nesse sentido, que o narod vivesse como um fora da lei era algo positivo, pois significava que não se rendera totalmente a uma ordem que lhe era alheia e hostil:

O camponês russo que tem, como o Sr. corretamente observou, uma forte aversão a toda forma de propriedade latifundiária, e que é imprudente e indolente por temperamento, encontrou-se preso, gradual e imperceptivelmente, nos tentáculos da burocracia alemã e do poder feudal. Ele submeteu-se a tal jugo degradante com - eu concordo - a passividade do desespero, porém nunca acreditou na autoridade de seu senhor, tampouco na justiça dos tribunais nem na equidade da administração. (...) Escorraçado por todos os lados, o povo adivinhou que o governo não está a seu favor mas contra ele, que o único objetivo da administração e da nobreza é extrair dele a maior quantidade possível de dinheiro. Percebendo isso, ele os engana a todos, o tempo todo. E nem poderia agir diferentemente, pois, se não roubasse deles (e observe que o camponês é acusado de roubar quando meramente esconde alguma parte do produto de seu próprio trabalho), então admitiria os direitos dos proprietários de terra e a justiça daqueles que o julgam. ${ }^{123}$

Quanto à veneração do Tsar pelo povo, Herzen garante que não se trata de respeito pela pessoa do imperador, mas por uma ideia abstrata, um mito enraizado na imaginação do mujique. Já a influência do clero é inegável, e embora o povo tenha total fé naquilo que dizem os monges,

${ }^{123}$ P. 180. 
estes lhe são de todo indiferentes. Uma exceção é aberta para os Dissidentes da Igreja Ortodoxa, chamados Velhos Crentes, sobre os quais Herzen afirma que têm tanto ódio ao Tsar quanto aos padres, aproximando-se, assim, do povo. Mas o fundamental é que, à parte o imperador e o clero, nenhum outro elemento da sociedade oficial e da administração tem qualquer apelo junto ao mujique.

O camponês russo não conhece outra realidade além daquela da vila camponesa: seus únicos direitos e deveres são aqueles ligados à comunidade e seus membros. Fora da comunidade ele não tem quaisquer obrigações, pois encontra apenas violência.

Há um fato que jamais foi negado por ninguém que tenha tido contato em primeira mão com o povo russo. É o fato de que eles muito raramente traem uns aos outros. Uma boa fé quase sem limites prevalece entre eles: contratos e autorizações por escrito lhes são praticamente desconhecidos. (...)

Os laços entre camponeses da mesma comuna são muito mais estreitos se não se tratar de uma comuna ortodoxa, mas dissidente. (...) É no curso das perseguições aos dissidentes que se pode ver o camponês russo como ele realmente é e observar a solidariedade que o liga a seus companheiros. (...) O mujique não tem outra moralidade senão a que flui como instintiva e naturalmente de sua vida comunitária: é uma moralidade profundamente nacional em caráter e o pouco que ele sabe das Sagradas Escrituras o fortifica nela: a chocante corrupção do governo e dos senhores de terra o conecta ainda mais aos seus costumes tradicionais e a sua comunidade. ${ }^{124}$

É impossível não pensar em Dostoiévski ao ler estas palavras. Há aqui novamente o paradigma do povo que se mantém coeso à força das perseguições que sofre (realidade

\footnotetext{
${ }^{124}$ Pp. 183-185.
} 
experimentada pelo narod, mas que serve como analogia para a Rússia em relação ao resto do mundo). Mais ainda, é alta a probabilidade de, em 1851, quando Dostoiévski regressava do exílio, tendo a Casa dos Mortos fresca em seu espírito, ter-lhe causado um grande impacto um quadro dando aos Velhos Crentes o aspecto de mártires, opondo-os à burocrática e cesaropapista Ortodoxia Oficial. Se Joseph Frank estiver certo em posicionar Herzen como difusor de um novo Eslavofilismo socialista, ao longo dos anos 50, podemos sem medo elencar Dostoiévski como um dos receptáculos dessa influência - a qual se conjugou, é claro, com a experiência siberiana e ideias já parcialmente semeadas no pensamento do escritor.

Ao longo de sua exposição, Herzen tece uma crítica implacável ao tsarismo, ao qual ele opõe, ora a noção de liberalismo, ora a de civilização. Herzen é um grande apologista da educação e da cultura, e a seus olhos nenhum regime baseado na instrumentalização massificante de parte da população é defensável. Ao fim e ao cabo, seu apelo em prol da liberdade individual é a outra face de sua exortação da civilidade ou ilustração. O autoritarismo do Estado tem como contraparte um tipo de coletivismo social hostil às individualidades, e sem individualidade não há ilustração e cultivo da personalidade. O socialismo idealizado por Herzen, desse modo, se lhe afigurava como um modelo onde, a exemplo da comuna camponesa russa em relação ao Estado tsarista, os homens se organizariam livremente, sem ter de obedecer a qualquer instância superior a si próprios:

A comuna rural russa subsiste desde tempos imemoriais e sua forma se mantém semelhante em todas as tribos eslavas. Em locais onde ela não existe, é porque sucumbiu sob a influência germânica. Entre os Sérvios, os Búlgaros e os Montenegrinos ela se conserva ainda mais pura do que na Rússia. A comuna rural representa por assim dizer uma unidade 
social, uma pessoa moral; ela é a proprietária e a responsável por todos e qualquer um, e portanto é autônoma em tudo o que diz respeito a seus assuntos interiores. ${ }^{125}$

Ele rejeita a afirmação de Haxthausen de que o presidente da comuna é como um pequeno tsar:

O presidente tem uma grande autoridade sobre cada membro, mas não sobre a comuna; por pouco que esta seja unida, ela pode muito bem contrabalancear o poder do presidente, obrigá-lo mesmo a renunciar a seu posto, se ele não quiser se dobrar à sua voz. O círculo das atividades do presidente é inteiramente administrativo; todas as questões que vão além de uma simples medida policial são resolvidas, ou segundo os costumes em vigor, ou pelo conselho de anciãos, ou enfim pela Assembleia Geral. Haxthausen cometeu um grande erro ao dizer que o presidente administra despoticamente a comuna. ${ }^{126}$

E, por outro lado, o socialismo ideal teria de superar aspectos negativos da comuna, notadamente o fato de ela absorver as individualidades, sufocando-as sob seu princípio social coletivista:

Haxthausen realmente entendeu o princípio vivificante do Povo russo; mas, em sua prevenção nativa contra tudo que é patriarcal e sem nenhum talento para a crítica, ele não viu que foi precisamente a parte negativa da vida comunitária que propiciou a reação de Petersburgo. Se não tivesse havido a completa absorção da personalidade na comuna, essa autocracia, de que fala Custine com um medo assaz justificável, não teria podido se formar. ${ }^{127}$

\footnotetext{
${ }^{125}$ La Russie (1849).

${ }^{126}$ La Russie

${ }^{127}$ Idem.
} 
Assim, num círculo vicioso, a estrutura interna da comuna, ao privilegiar o coletivo em detrimento do cultivo individual, possibilitara, no passado, o desenvolvimento de um Estado autoritário, uma vez que a massa popular fora criada, sob os princípios comunais, para não ter voz própria; e, ao mesmo tempo, sufocada pela autocracia já bem estabelecida, era cada vez mais difícil para as populações das comunas, e para a comuna enquanto modelo socioeconômico, desenvolverem todo o seu potencial. É assim que uma aproximação das ideias revolucionárias europeias é imprescindível à maturação do socialismo russo, ao mesmo tempo em que estas, sem o modelo vivo do narod, estão fadadas ao fracasso:

É uma bênção para a Rússia que a comuna rural não se tenha desintegrado, que a propriedade privada jamais tenha substituído a propriedade típica da comuna: como teve sorte o povo russo, ao ter estado alheio a quaisquer movimentos políticos e, nesse sentido, à civilização europeia, a qual teria certamente minado a vida da comuna, e que hoje, com o socialismo, alcançou sua própria negação.

A Europa, como já apontei em outro momento, jamais resolveu a antinomia do Estado e do indivíduo, mas ainda assim propôs o problema. A Rússia aborda o mesmo problema desde um ponto de vista muito diverso, mas não teve um sucesso muito maior em encontrar uma solução. É, portanto, na sombra desse problema que encontramos a fonte de nossa igualdade. ${ }^{128}$

Herzen segue enfatizando que, no processo de se resgatar o movimento revolucionário europeu pelo modelo da comuna russa, o mérito não é da intelligentsia, mas do "próprio povo em sua vida cotidiana". A intelligentsia seria tão somente "a ponte entre o povo russo e a Europa revolucionária"; o futuro da Rússia estava mesmo nas mãos do mujique.

${ }^{128}$ P. 189. 
Porém - e aqui estamos diante de nova contradição interna de seu pensamento -, logo após analisar em detalhes a alma do narod e reconhecer-lhe o conservadorismo, o apego à família e às tradições religiosas (“A família é algo altamente desenvolvido entre as raças eslavas: é possível que tenhamos aí a fonte de seu conservadorismo, o limite de sua tendência negativa"p. 190), tudo isso a propósito da caracterização do camponês russo como portador da ideia que triunfará sobre a negatividade do Ocidente, Herzen passa a discorrer sobre o russo em geral, notadamente as classes educadas (e ele mesmo, presume-se), e neste ponto sua argumentação muda de tom: ele passa a gabar-se da "independência moral" do russo e de seu desapego ao passado e a tradições, o que o colocaria em posição de vantagem em relação à Europa aferrada a sua cultura milenar:

O russo emancipado é a criatura mais independente do mundo. E, de fato, o que poderia haver para contê-lo? Um senso de passado? (...) Nós compartilhamos do seu [do Ocidente] ceticismo - é a sua fé que não nos anima. Vocês são muito religiosos para nós. Nós podemos compartilhar de suas animosidades - é o seu apego ao legado do passado que nos é incompreensível. Nós somos muito oprimidos, muito devastados para aceitar uma meia liberdade. Vocês têm seus compromissos a considerar, seus escrúpulos para contê-los - mas nós não temos nada disso, nem compromissos nem escrúpulos, apenas é que nesse momento estamos impotentes. Não nos acusem de ser imorais apenas porque não respeitamos o que vocês respeitam. Você condenaria uma criança abandonada por não respeitar seus pais? Nós somos agentes livres, pois nos fizemos por nossa própria conta. ${ }^{129}$

Neste ponto Herzen está evidentemente falando pela intelligentsia, não mais pela população camponesa. É como se o conservadorismo do mujique fosse louvável apenas na

\footnotetext{
${ }^{129}$ Pp. 198-199.
} 
medida em que possibilitara a preservação da comuna rural, por sua vez alentada - segundo nos explica o próprio Herzen - pela resistência de grupos dissidentes tanto em relação ao Estado quanto em relação à Igreja oficial, mas ainda assim fervorosamente religiosos ao ponto de arriscar sua liberdade para não trair suas convicções em relação à verdadeira Ortodoxia. Ou seja, Herzen reconhece a conveniência do conservadorismo popular face à necessidade premente de se resistir à opressão do Império e do regime de servidão, mas não reconhece sua legitimidade intrínseca. Este é, como veremos, seu principal ponto de divergência com Dostoiévski no que diz respeito ao narod.

Herzen e Dostoiévski têm em comum a exaltação de um papel de destaque para Rússia no cenário político internacional e das qualidades originais do jovem povo russo. Porém, assim como seu ódio ao burguês europeu era semelhante apenas na superfície, tendo no fundo motivações totalmente diversas e até contraditórias, seu nacional-populismo também será marcado por cruciais diferenças.

\subsubsection{Dostoiévski entre a inspiração e a ideologia}

Ferrenho combatente de utopias reducionistas, Dostoiévski não deixou de idealizar a sua própria. Mesmo os críticos mais próximos de sua visão de mundo (Berdiáiev, Ellis Sandoz, René Girard) não deixam de notar este seu ponto fraco: Dostoiévski identificou problemas e escancarou feridas, e o fez com precisão inacreditável, mas não obteve o mesmo êxito quando tentou propor soluções. Um exemplo sumário disto se dá em sua representação de duas personagens antagônicas: Ivan e Aliócha Karamázov. Não será exagero dizer que as falas de 
Ivan no famoso diálogo entre os dois irmãos, que ocupa o que são provavelmente os três principais capítulos de Os Irmãos Karamázov, fecundaram com sua angústia e suas dúvidas toda a história intelectual do século XX, na Rússia como no Ocidente. Porém, não é possível dizer o mesmo de Aliócha e seu stárietz Zossima, ainda que suas falas contenham as ideias "positivas" do próprio Dostoiévski ${ }^{130}$.

Nas Notas de Inverno se dá algo semelhante: os pontos mais fortes do texto, onde o narrador é mais eloquente em suas tiradas ácidas, referem-se às críticas feitas tanto à Europa quanto à Rússia. Já os momentos em que é exposta a utopia pessoal de Dostoiévski deixam o leitor pouco convencido; por mais que a porção pótchviennik-eslavófila do discurso do narrador desperte interesse, destoa do - por assim dizer - dinamismo do resto. Dostoiévski nos acostuma a sempre considerar um objeto por seus ângulos mais contrários, nos convence de que a verdade, não sendo mutável, é ainda assim bem mais complexa do que os esquemas conceituais e simbólicos que inventamos para expressá-la. E, ao fazê-lo, ele paradoxalmente se aproxima da verdade; mas, ao mesmo tempo, por uma imperfeição em sua consciência artística, julga necessário apresentar também um modelo em duas dimensões do que acabou de expressar com a eloquência fulminante de seu "realismo superior" - e aí prejudica a harmonia do conjunto.

Tanto a "Lenda do Grande Inquisidor" quanto os sermões do stárietz Zossima são inspirados pela mesma intuição da verdade, com a diferença de que Zossima é esta inspiração desfigurada pela ideologia naródnik de Dostoiévski. Como bem notou Nikolai Berdiáiev, "no Cristianismo russo há sempre o grave perigo da predominância do elemento popular sobre o

\footnotetext{
${ }^{130}$ Para certificar-se disto basta comparar o Livro VI de Os Irmãos Karamázov, no qual estão reunidos os sermões de Zossima, com os artigos de Dostoiévski no Diário de um escritor.
} 
Logos Universal, da alma sobre o espírito. Este perigo pode ser visto no próprio Dostoiévski: sua divindade é com frequência o deus russo e não o Deus universal."131

Outra importante diferença é que a Lenda se insere no labirinto de contrários que é $O s$ Irmãos Karamázov, e sua força advém justamente de conseguir sustentar-se diante de todas as tensões adversas que a provam por todos os lados. Já o Livro VI, “Um Monge Russo”, onde Aliócha compila as falas e sermões de seu mestre, soa como um adendo artificial aos capítulos anteriores. Aí já não fala mais o Dostoiévski artista e sim o ideólogo; as intuições luminosas dão lugar ao wishful thinking.

O ponto a ser enfatizado é que talvez esse "anticlímax" representado, nos Karamázov, pelo Livro VI (e, em outras obras, por outras falas ou personagens) esteja na origem da universalmente experimentada dificuldade de se precisar o sentido da obra de Dostoiévski, ao ponto de haver quem tome tal dificuldade por impossibilidade. É como se Dostoiévski criasse seu próprio espantalho e desviasse, involuntariamente, a atenção do leitor a um pastiche (o Livro VI) da verdade que acabou de expressar em toda a sua vivacidade e complexidade (a Lenda). Então, o leitor desavisado, distante da cosmovisão de um Zossima e culturalmente predisposto a compartilhar da angústia de Ivan, entende, para seu comodismo, que a "lição de moral" do livro está naquelas falas adocicadas do velho monge, e que portanto o poema alucinado do jovem intelectual Karamázov só pode ocupar-se de outra coisa, só pode ter valor "negativo", já que a “positividade" está expressa alhures. É de fato muito difícil entender que textos tão distintos um tão próximo de nós, outro tão olimpicamente frígido - sejam tentativas de expressão da mesma verdade.

No fundo, o grande problema é aproximar-se de Dostoiévski buscando nele as categorias de "positivo" e "negativo"; se há, de fato, ideias com que Dostoiévski tem afinidade e outras a

${ }^{131}$ BERDYAEV, N. Dostoevsky. Meridian Books: 1968, p. 185. 
que é hostil, sua expressão literária da dinâmica entre essas ideias e os sujeitos e sociedades que as produziram é bem mais complexa. Pode-se, para fins didáticos, elencar Ivan Karamázov entre as "personagens negativas" de Dostoiévski: o tipo social e psicológico por ele representado era considerado pelo autor como um aspecto doentio da cultura russa. Porém, o que dizer da "Lenda do Grande Inquisidor", produto da imaginação de Ivan e inserida no romance a partir de suas falas? Seria a Lenda também "negativa"? O próprio Dostoiévski considerava que não:

A ideia [do capítulo "Revolta"] é apresentar o extremo da blasfêmia e as sementes da ideia de destruição, na Rússia deste momento, entre a geração de jovens que se apartaram da realidade. As convicções de Ivan formam o que eu considero a síntese do anarquismo russo contemporâneo. A negação não de Deus, mas de Sua criação. Todo o socialismo emergiu da negação do sentido da atualidade histórica e chegou ao programa da destruição e do anarquismo. Os principais anarquistas eram, em muitos casos, homens sinceramente convictos. Meu herói escolhe um tema e, em minha opinião, um tema inexpugnável: a falta de sentido do sofrimento das crianças - e daí deduz a absurdidade de toda a atualidade histórica... E a blasfêmia do meu herói será triunfantemente refutada no próximo capítulo ["O Grande Inquisidor"], no qual estou trabalhando agora com temor e tremor, pois considero minha tarefa (a refutação do anarquismo) uma proeza cívica. ${ }^{132}$ (Grifo meu)

Como se vê, para Dostoiévski estava muito clara a disposição de "negatividade" e "positividade" entre os capítulos "Revolta" e "O Grande Inquisidor". Ainda assim, é um fato que a constituição artística da Lenda envolve ambas as noções, pondo-as em franco embate, e durante este embate ambas estão como em pé de igualdade: se o bem vence no final, é após uma batalha

${ }^{132}$ Carta a N. A. Liubímov, 10 de Maio de 1879. In: Fyodor M. Dostoevsky, "Dostoevsky on The Brothers Karamazov", New Criterion, IV (1926), 552-553. 
sangrenta, da qual o autor não exclui mesmo as armadilhas mais perigosas, ainda que sua simpatia esteja o tempo todo com o Cristo torturado. E não é por acaso que a Lenda é assim composta: se Dostoiévski poupasse sua "ideia positiva" (Cristo) de qualquer dos ataques da "negatividade" (a revolta de Ivan; o Grande Inquisidor), não demonstraria satisfatoriamente sua solidez. O pouco poder de convencimento do Livro VI advém justamente de seu isolamento quanto a forças contrárias.

Note-se ainda que isto é análogo ao próprio procedimento de Cristo junto aos homens, segundo exposto na Lenda. Deus permite a existência do mal enquanto condição de possibilidade da liberdade humana: é preciso que os homens sobrevivam ao vale de lágrimas terreno lutando apenas com a força do exemplo dado por Cristo, pois de outro modo serão títeres nas mãos do poder divino, não criaturas dotadas de vontade (livre arbítrio). Ou seja, como o Cristo dostoievskiano diante do Grande Inquisidor, o único modo de o homem demonstrar sua dignidade e grandeza é enfrentando o mal; Dostoiévski não poupa suas próprias crenças de descer à arena para digladiar-se com crenças contrárias do mesmo modo como Deus permite o mal entre os homens.

E o mais curioso é que em ambos os casos tal procedimento gera confusão. Com a "Lenda do Grande Inquisidor", Dostoiévski de fato refuta a revolta de Ivan Karamázov - do ponto de vista intelectual e textual. Porém, é controverso afirmar o sucesso de tal refutação enquanto "proeza cívica”, isto é, o quanto a obra artística de Dostoiévski é culturalmente eficaz na defesa dos valores que se propõe sustentar. No fim das contas, os últimos cento e trinta anos têm mostrado que muitos de seus leitores não conseguem acompanhar o combate sutil entre Cristo e o Grande Inquisidor, saindo da Lenda incertos quanto a seu sentido, especialmente no 
contexto maior de Os Irmãos Karamázov, com o eslavofilismo de Zossima e silhueta vaga de Aliócha complicando o coro de vozes.

Como dito acima, este percurso entre o questionamento iluminador e o reducionismo ideológico é também discernível nas Notas de Inverno. As questões que o narrador-viajante de Dostoiévski levanta sobre as relações entre a Rússia e o Ocidente, valendo-se da imagem do trem que transita entre fronteiras, são realmente notáveis. Vejamos algumas delas:

“Meu Deus, que espécie de russos nós somos?” - vinha-me por vezes à mente, sempre sentado no vagão. - "Somos realmente russos? Por que a Europa exerce sobre nós, sejamos quem formos, uma impressão tão forte e maravilhosa, e tamanha atração? Isto é, não falo agora dos russos que lá ficaram, daqueles russos de modesta condição, que se chamam cinquenta milhões, e a quem nós, que somos cem mil, até agora consideramos com toda a seriedade como sendo ninguém e de quem as nossas tão profundas revistas satíricas ainda hoje zombam, pelo fato de não rasparem as barbas. Não, falo agora do nosso grupinho privilegiado e patenteado. Porque tudo, decididamente quase tudo o que em nós existe de desenvolvido, ciência, arte, cidadania, humanismo, tudo, tudo vem de lá, daquele país das santas maravilhas! Toda a nossa vida se dispôs em moldes europeus, já desde a primeira infância. Será possível que algum de nós tenha podido resistir a esta influência, a este apelo, a esta pressão? Como foi que ainda não nos transformamos definitivamente em europeus? Creio que todos concordarão que ainda não nos transformamos - o que, em uns, despertará alegria, e em outros, naturalmente, rancor por não estarmos suficientemente crescidos para a transformação. (...) Existirá realmente uma associação química, entre o espírito humano e o 
solo pátrio, que torne impossível a alguém separar-se definitivamente deste, e de modo tal que, se dele se separa, acaba sempre por voltar?"133

Este trecho inaugura a argumentação pótchviennik nas Notas. Nele a retórica sugestiva de Dostoiévski já funciona a plenos pulmões: o narrador começa dando como fato consumado a separação entre os "cinquenta milhões" (o povo) e os "cem mil" (a classe educada), para então fazer a pergunta-chave: "Como foi que ainda não nos transformamos definitivamente em europeus?" Já vimos que um dos objetivos do Pótchviennitchestvo era abolir a noção de que as classes educadas eram menos "povo" do que o povo simples. É assim que a pergunta feita ao fim da citação - "Existirá uma associação química entre o espírito humano e o solo pátrio?” - é com efeito uma pergunta retórica: Dostoiévski acredita que sim, existe tal associação, e um russo, por mais europeia que tenha sido sua educação, terá sempre a alma de um russo. Mas a resposta positiva à pergunta é dada (como de costume) de forma indireta: Dostoiévski toma o exemplo de Fonvízin, "uma jaqueta francesa que escreveu O Brigadeiro", para mostrar como o espírito russo resiste mesmo à mais emperucada tentativa de fazer-se europeu. Fonvízin e toda a sua geração, trajados como perfeitos cavalheiros e damas franceses, ainda assim se permitiam rir do aforismo, de autoria de Fonvízin, segundo o qual "o francês não tem juízo":

...transportei-me para os tempos de antanho e refleti sobre o homem que formulou o citado aforismo a respeito do juízo do francês, e fiquei pensativo, sem mais nem menos, justamente a propósito do aforismo. Esse homem era, em relação à época, um grande liberal. Mas, embora usasse a vida inteira, não se sabe para quê, jaqueta francesa, pó-de-arroz e um espadim para trás, a fim de apregoar a sua origem cavalheiresca (que entre nós não existiu sequer) e para defesa de sua honra pessoal na antessala de Potiômkin, mal pôs o nariz para

\footnotetext{
${ }^{133}$ Notas, p. $79-80$.
} 
fora das fronteiras russas, começou a renegar Paris com todos os textos bíblicos e decidiu que “o francês não tem juízo". ${ }^{134}$

Atentemos a este novo exemplo do jogo dostoievskiano de sugestão e confusão de expectativas: o narrador iniciara o capítulo citando um aforismo de Fonvízin sobre a falta de juízo do francês - e o leitor pôs-se a esperar que ele fornecesse, com sua experiência de viajante, exemplos concretos nesse sentido. Porém, o capítulo volta-se a Fonvízin e aos russos, não aos franceses, e por fim sugere-se a falta de juízo de Fonvízin e daqueles que, como ele, riam de seu reflexo no espelho, ignorando tratar-se seu próprio reflexo. Contudo, numa nova virada, a contradição personificada por Fonvízin não deixa de ter uma conotação positiva: pela perspectiva pótchviennik, o fato de o afrancesado dramaturgo russo fazer piada sobre os franceses que imita demonstra que seu espírito russo está intacto sob todo o aparato ocidental com que se fantasia.

Para Dostoiévski e os pótchvienniki, este ato falho de Fonvízin reflete seu instinto para a liberdade, sua necessidade humanamente congênita de caçoar das formas fixas e das verdades pré-fabricadas. Dostoiévski desenvolve essa ideia em um trecho extraordinário das Notas:

Ah, como é enfadonho ficar sentado ociosamente num vagão de trem, tal como é aborrecido em nossa Rússia viver sem uma ocupação. Embora estejam transportando você, se preocupem com você e de vez em quando até o embalem tanto que, parece, não há mais o que desejar, apesar de tudo uma angústia o invade, e esta angústia procede justamente do fato de que você mesmo não faz nada, porque cuidam demais de você, e você tem que ficar sentado, esperando que o levem ao destino. Palavra, às vezes dá até vontade de saltar para fora e sair correndo, com as próprias pernas, ao lado da máquina. Que seja pior, vá lá que me canse por falta de hábito, me desvie do caminho, e tudo sem necessidade! Em compensação, vou com

${ }^{134}$ Notas, p. 83. 
minhas próprias pernas, encontrei o que fazer e me ocupo pessoalmente de minha tarefa e, se acontecer chocarem-se os vagões e voarem virados para cima, eu não estarei trancado no vagão, não responderei com os meus costados pela culpa alheia... ${ }^{135}$

Trata-se da mais pura expressão do oblomovismo, doença que acometia muitos russos "supérfluos", os quais não conseguiam encontrar seu nicho de atuação porque tinham seu vigor original paralisado pela saciedade material e pela indolência - a exemplo da personagem antológica de Ivan Gontcharóv. Em nível social, a metáfora do vagão de trem recobre, por um lado, a crítica à ideia ocidentalista de que o futuro da Rússia consistia apenas em colocar-se no caminho desbravado pela Europa e deixar-se conduzir pelas luzes dessa benfeitora mais capacitada e experiente; e por outro, trata-se da mesma crítica feita nas Memórias do Subsolo a modelos sociais planificados, dos quais o formigueiro e o Palácio de Cristal são metáforas: ainda que seja materialmente mais vantajoso habitar estes reinos da escravidão justificada, o espírito humano busca sempre a liberdade, ainda que à custa de prejuízos materiais imediatos ${ }^{136}$.

A estes comentários negativos, isto é, críticos, onde Dostoiévski dá tratamento irônico aos temas mais sérios de seu tempo, obtendo daí seus melhores resultados enquanto pensadorartista, soma-se sua análise do lema da Revolução Francesa, citada acima ${ }^{137}$. Mas é também por ocasião desta análise que se dá a virada mais propriamente eslavófila das Notas - e seu “anticlímax” ideológico.

É preciso diferenciar o Dostoiévski pótchviennik do eslavófilo, ou pan-eslavista, sendo que este último termo se aplica mais à sua fase final, com o Diário de um escritor e Os Irmãos

\footnotetext{
${ }^{135}$ Notas, p. 81.

${ }^{136}$ Outra versão desta metáfora é dada no conto fantástico $O$ Crocodilo, no qual um funcionário russo é engolido por um crocodilo, em que passa a habitar, analogamente ao viajante ocioso sendo transportado dentro de um vagão de trem.

${ }^{137}$ Cf. p. 76.
} 
Karamázov. Enquanto pótchviennik, Dostoiévski sustentou o discurso conciliatório característico do Movimento do Solo Pátrio, mas, ao longo dos anos 60, o exclusivismo russo - a ideia de que a Rússia tinha qualidades inexistentes em outros países, cabendo-lhe, portanto, o papel de liderança naquele momento da história dos povos - foi ganhando cada vez mais preponderância em seu pensamento.

Segundo Joseph Frank, foi durante a segunda viagem que fez à Europa, em 1863, que Dostoiévski leu pela primeira vez os autores eslavófilos clássicos, os quais até então só conhecia por fontes secundárias: “O aparente Eslavofilismo de Dostoiévski no início dos anos 60 fora assimilado através de Bielínski e Herzen." ${ }^{\text {138 }}$ Porém, é só nos eslavófilos que Dostoiévski encontra uma base teológica para tais ideias nacionalistas: "A teologia eslavófila era fortemente anticatólica e atribuía todos os males da humanidade, no passado e no presente, ao fato de ter o Papa assumido o poder temporal que outrora era dos imperadores romanos. (...) Dostoiévski já era anticatólico antes de ler os eslavófilos, mas estes lhe deram uma base conceitual abrangente."139

Assim, se no Pótchviennitchestvo a religião ortodoxa era apenas um entre outros aspectos da cultura russa, a partir de meados da década de 60 a ênfase eslavófila na Ortodoxia é incorporada aos escritos de Dostoiévski. Como já assinalamos, é nesse período que ele chega à conclusão de que uma sociedade perfeitamente fraterna é impossível na Europa, estando, porém, ao alcance do povo russo, cujo potencial para o "amor ativo" fora preservado pela cultura camponesa.

As Notas de Inverno Sobre Impressões de Verão, escritas poucos meses antes da segunda visita de Dostoiévski à Europa, nos mostram quão próximo ele já estava dos eslavófilos mesmo

\footnotetext{
${ }^{138}$ FRANK, J. Os Efeitos da Libertação - 1860-1865. Trad. Geraldo Gerson Souza. São Paulo, Edusp: 2002, p. 379.

${ }^{139}$ Idem, p. 379-380.
} 
antes de estudá-los a fundo; nas Notas já há, de fato, um sensível distanciamento do "murismo" pótchviennik. Mas, como veremos em seguida, o vocabulário humanista ainda não dera lugar, aí, à franca apologética ortodoxa que marcaria os escritos de Dostoiévski pouco tempo depois.

O trecho em que Dostoiévski faz seu narrador-viajante expor sua utopia pótchviennikeslavófila tangencia diversos problemas de seu pensamento, iluminando inclusive seus pontos de discordância com Herzen, o que nos obriga a analisa-lo de perto.

\subsubsection{Um dom dado de graça: a fraternidade naródnik}

Após mostrar que na Europa de seus dias não havia nem liberdade nem igualdade, Dostoiévski ataca a noção ocidental de fraternidade:

(...) O que subsiste, pois, da fórmula? A fraternidade. Ora, este ponto é o mais curioso e, deve-se confessar, constitui no Ocidente, até hoje, a principal pedra de toque. O ocidental refere-se a ela como a grande força que move os homens, e não percebe que não há de onde tirá-la, se ela não existe na realidade. O que fazer, portanto? É preciso criar a fraternidade, custe o que custar. Verifica-se, porém, que não se pode fazer a fraternidade, porque ela se faz por si, concede-se por si, é encontrada na natureza. Todavia, na natureza do francês e, em geral, na do homem do Ocidente, ela não é encontrada, mas sim o princípio pessoal, individual, o princípio da acentuada autodefesa, da auto-realização, da autodeterminação em seu próprio Eu, da oposição deste Eu a toda a natureza e a todas as demais pessoas, na qualidade de princípio independente e isolado, absolutamente igual e do 
mesmo valor que tudo o que existe além dele. Ora, uma tal auto-afirmação não podia dar origem à fraternidade. Por quê? ${ }^{140}$ (Grifos meus)

Ao afirmar que a fraternidade é impossível no Ocidente pelo fato de que não existe na natureza do homem ocidental, Dostoiévski abre caminho para a afirmação, a ser feita mais adiante, de que a semente fraterna existe no homem russo, e exclusivamente nele. Mas por enquanto nos detenhamos ainda na parte "negativa" deste trecho: a análise de o quê, em lugar da fraternidade, encontra-se na natureza do homem europeu. Esta fala do narrador nos interessa imensamente, já que descreve, de forma bastante acurada, a ética de Herzen: “o princípio pessoal, individual, o princípio da acentuada autodefesa, da auto-realização, da autodeterminação em seu próprio $\mathrm{Eu}$, da oposição deste Eu a toda a natureza e a todas as demais pessoas, na qualidade de princípio independente e isolado, absolutamente igual e do mesmo valor que tudo o que existe além dele."

Tudo isto, de fato, são princípios do egoísmo herzeniano, do qual Dostoiévski capta a contradição fundamental: o Eu é considerado um ente autodeterminado e independente da natureza geral e de todas as demais pessoas, mas ao mesmo tempo todos os Eus são declarados iguais e do mesmo valor. O problema é que, sendo válida esta última afirmação, anula-se a primeira, pois se todos são iguais e do mesmo valor, então têm a mesma natureza, logo não é o Eu que se determina, mas sua natureza extrínseca, comum a todos. Já vimos acima que essa contradição, que não está no pensamento de Herzen exclusivamente, mas na base da mentalidade socialista, para Dostoiévski estava fadada a degenerar em despotismo, pois sempre será necessário um eixo de autoridade pelo qual regular sociedades nas quais a moral natural, baseada na regularidade da natureza humana, foi relativizada.

\footnotetext{
${ }^{140}$ Notas, p. 131.
} 
Porém, a explicação oferecida nas Notas de por que o princípio da auto-afirmação não pode dar origem à fraternidade não é de interpretação simples. Como em Os Irmãos Karamázov, aqui se misturam intuições geniais com a mais intransigente ideologia populista. $\mathrm{O}$ início do argumento trata de definir a "fraternidade autêntica", para contrapô-la melhor à sua "versão marretada", o socialismo:

Ora, uma tal auto-afirmação não podia dar origem à fraternidade. Por quêe Porque na fraternidade, na fraternidade autêntica, não é uma personalidade isolada, um Eu, que deve cuidar do direito de sua equivalência e equilíbrio em relação a tudo o mais, e sim todo este "o mais" é que deveria chegar por si a essa personalidade que exige direitos, a esse Eu isolado, e espontaneamente, sem que ele o peça, reconhecê-lo equivalente e de iguais direitos a si mesmo, isto é, a tudo o mais que existe no mundo. Mais ainda, esta mesma personalidade revoltada e exigente deveria começar por sacrificar todo o seu Eu, toda a sua pessoa, à sociedade, e não só não exigir o seu direito, mas, pelo contrário, cedê-lo à sociedade, sem quaisquer condições. (...)

Toda personalidade diria à sociedade, por si, sem a menor coação, sem buscar qualquer vantagem: "Somente unidos seremos fortes: tomai-me todo, se precisais de mim. (...) Vou destruir-me, fundir-me com toda a indiferença, contanto que a vossa fraternidade não morra." E a fraternidade, ao contrário, deve dizer: "Estás nos dando demais. Não temos direito de não aceitar de ti aquilo que nos entregas (...). Toma, pois, tudo de nós também. Vamos esforçar-nos constantemente para que tenhas o máximo de liberdade individual, o máximo de auto-expressão.” (...) Depois disso, naturalmente, não há mais o que dividir, tudo se dividirá por si. Amai-vos uns aos outros, e tudo vos será concedido. ${ }^{141}$

${ }^{141}$ Notas, p. 131 e 133. 
Prevendo a desconfiança do leitor ante o quadro descrito, o narrador apressa-se ele mesmo em chamá-lo de utópico:

Mas, realmente, que utopia, meus senhores! Tudo baseado no sentimento, na natureza, e não na razão. Mas isto até parece uma humilhação da razão. O que lhes parece? É utopia ou não é? Mas, torno a dizer, o que pode fazer o socialista, se o homem ocidental não possui o princípio fraterno, e se, pelo contrário, o que existe nele é um princípio individual, pessoal, que exige de espada na mão os seus direitos? Vendo que não há fraternidade, o socialista põe-se a convencer as pessoas à fraternidade. Ele que produzir, compor a fraternidade. Para fazer um ragu de lebre, é preciso ter em primeiro lugar a lebre. Mas no caso falta a lebre, isto é, uma natureza capaz de fraternidade e que nela acredite, tenda para ela espontaneamente. ${ }^{142}$

Por meio dessas palavras o leitor vai aos poucos sendo introduzido no terreno da ideologia eslavófila: à força da repetição de que a utopia descrita é impossível no Ocidente, compreendemos que pode ser possível em outro lugar, e que portanto não se trata de um ideal tão utópico assim. Este lugar privilegiado será, evidentemente, a Rússia - e então o argumento antiocidental de Dostoiévski perde grande parte de sua força, pois, ao fim e ao cabo, revela-se menos um argumento anti-ocidental do que pró-russo; sua ideia básica é que o povo russo é capaz da fraternidade como por um dom natural, formado em seu espírito ao longo de milênios e portanto exclusivo, impossível de ser reconstituído artificialmente entre outros povos:

A personalidade ocidental exige à força o seu direito, ela quer "participar", e disso não resulta fraternidade. Está claro: ela pode transformar-se? Mas semelhante transformação

\footnotetext{
${ }^{142}$ Notas, p. 133-134.
} 
leva milênios, porque tais ideias devem antes entrar na carne e no sangue para se tornarem realidade.

(...) Não se pode fazer nada, é preciso que tudo se faça por si, que exista na natureza [grifo de Dostoiévski], que seja compreendido inconscientemente na natureza de todo um povo, numa palavra, que haja um princípio fraterno, de amor: é preciso amar. É preciso que se tenda instintivamente à fraternidade, à comunhão, à concórdia, e que se tenda apesar de todos os sofrimentos seculares da nação, apesar da escravidão secular, das invasões estrangeiras, numa palavra, que a necessidade da comunhão fraterna faça parte da natureza do homem, que este nasça com ela ou tenha adquirido tal hábito através dos séculos. ${ }^{143}$

Ou seja, a fraternidade nunca será possível no Ocidente porque lá precisaria ser instituída à força - e nisso consiste o socialismo. Mas o povo russo, cuja pureza de alma foi preservada pela cultura camponesa, é capaz de viver fraternalmente sem precisar ser forçado a tanto. O narod, diferentemente dos europeus e dos russos europeizados (como Herzen), sabe, ainda que de modo inconsciente, que é parte de um organismo maior, ao qual pertence sem que isso represente a perda de sua individualidade; cada indivíduo da fraternidade naródnik idealizada por Dostoiévski vive não para si, mas para os outros; não, como Herzen, tendo como princípio norteador da vida a felicidade pessoal, mas a autodoação ao próximo. Este é, de fato, o princípio básico do Cristianismo, o qual não depende de deduções teológicas, mas se depreende da própria trajetória terrena de Cristo. Dostoiévski, em sua literatura, nos deu algumas imagens muito expressivas desse "amor ativo" de inspiração cristã (por exemplo, Sônia e Míchkin), imagens que revelam sua compreensão profunda da natureza do Cristianismo; porém, ao afirmar que a realização social da fraternidade autêntica é um privilégio do povo de seu país, o romancista afasta-se do Cristo universal para idolatrar seu deus russo.

\footnotetext{
${ }^{143}$ Notas, p. 131.
} 
Assim, pode-se dizer que o argumento antissocialista de Dostoiévski é razoável até o momento em que aponta a contradição interna da cosmovisão materialista, a qual afirma valores universais, como a liberdade e a igualdade entre os homens, porém confundindo-os, ilogicamente, com a afirmação do egoísmo e da autodeterminação moral dos indivíduos. Dostoiévski, ao longo de todos os seus grandes romances, mostra que, justamente por serem iguais, os homens pertencem a um organismo maior do que si mesmos, sendo no entanto livres para agir de acordo ou contra as leis desse organismo; o valor de suas ações não é estabelecido por eles, mas pela ordem que os contém, sendo que esta ordem não é a "sociedade" em sentido contratual ou jurídico, mas a própria natureza humana. Novamente, a melhor expressão literária desse problema é Raskólnikov, que atenta em primeiro lugar contra sua própria natureza e não deixa de sentir os efeitos dessa automutilação.

Porém, para que Dostoiévski pudesse consistentemente associar a mentalidade típica de Raskólnikov ao Ocidente e afirmar que a cultura naródnik de seu país possuía o antídoto para tal doença espiritual, precisaria evocar muito mais do que alguns casos de mujiques abnegados ou a capacidade de redenção dos presos siberianos. Em suma, quando analisa o drama dos homens tentando fazer bom uso de sua liberdade, Dostoiévski entende com clareza verdadeiramente genial os termos do problema, mas acaba submetendo-o aos critérios de seu nacionalismo e assim se afasta da verdade que começara a desvendar.

Não são os povos ocidentais ou eslavos que são capazes ou incapazes de viver em fraternidade: são os homens em geral. Dostoiévski, e os comparsas de seu chauvinismo, até poderiam atribuir à Europa a autoria de ideias e sistemas de pensamento que "contaminaram" o povo russo para o qual o Ocidente serviu de modelo; mas não teriam absolutamente como sustentar a ilusão de que, apesar de a classe letrada russa desenvolver-se em perfeita sintonia 
com o pensamento europeu, havia na alma russa um "ponto intocado" cuja expressão concreta era a vida camponesa. Faria sentido, sim, a afirmação de que um povo maciçamente cristão teria mais dificuldade para "converter-se" ao socialismo, porém o próprio Dostoiévski era o primeiro a reconhecer a "peculiaridade" do cristianismo do povo russo; seu erro parece ter sido justamente tomar tal peculiaridade por genuinidade e profundidade, quando hoje temos razões para crer que se tratava, na verdade, de um verniz cristão sem grandes consequências para além da esfera ritualística da vida cotidiana. Invocando novamente as palavras de Berdiáiev, "é muito importante que a vida religiosa de um povo não seja subordinada a um ponto de vista de classe, uma falta da qual nem Dostoiévski nem os eslavófilos estavam livres."

Essa exaltação do narod russo é constante nos escritos de Dostoiévski desde o Pótchviennitchestvo até o fim de sua vida. Há, contudo, algumas sensíveis diferenças entre as várias fases do populismo dostoievskiano. Nas Notas de Inverno, como já foi apontado, temos o momento de transição entre a cosmovisão pótchviennik e o Eslavofilismo mais estrito. Dostoiévski fala em fraternidade, em comunhão, em concórdia e cita com todas as letras o mandamento cristão sobre amar ao próximo - mas, em sua explicação de por que o povo russo tem o dom para a fraternidade, não enfatiza a religiosidade popular como fará em escritos posteriores. O recurso à religiosidade do povo está nas entrelinhas, porém depois virá a ocupar o espaço central da argumentação.

Por exemplo, em um de seus últimos artigos no Diário de um escritor, em 1880, Dostoiévski escreve:

Eu afirmo que nosso povo foi instruído há muito tempo, quando tomou Cristo e Seus ensinamentos como sua própria essência. Dirão que o povo não conhece os ensinamentos de

\footnotetext{
${ }^{144}$ Op. cit., p. 187.
} 
Cristo - mas é uma objeção oca: eles sabem tudo, tudo o que precisam saber, mesmo que talvez fossem reprovados num exame de catecismo. Eles aprenderam nas igrejas, onde por séculos ouviram preces e hinos que são mais eficazes do que sermões. Eles repetiam e cantavam essas preces enquanto ainda viviam nas florestas, tentando salvar-se de seus inimigos. (...) O padre lê "Ó Senhor, rei do meu ser" - e esta prece contém toda a essência do Cristianismo [grifo de Dostoiévski], todo o seu catecismo, e o povo conhece esta prece de cor. $^{145}$

Nas Notas de Inverno, o povo russo tem o "dom para a fraternidade"; no Diário de um escritor, tal dom transforma-se explicitamente na missão de levar adiante os ensinamentos de Cristo, perdidos no Ocidente desde que o Papa assumiu poder terreno, abrindo caminho ao ateísmo. Porém, mesmo nessa fase mais avançada de seu pensamento Dostoiévski mantém ainda alguns princípios pótchvienniki: por exemplo, ele recusa-se a ver entre a intelligentsia e o narod um abismo intransponível. Apesar de afirmar que o trunfo da Rússia está no seio do povo, que os russos europeizados tendem a desprezar o tesouro que é a cultura popular de seu país, e que mesmo aqueles que se aproximam do povo para "civilizá-lo" no fundo o desprezam, apesar de tudo isso Dostoiévski crê que um russo será sempre e até o fim um russo; quanto mais cheio de contradições, quanto mais representar um amálgama de referências conflituosas, mais um homem russo será russo - pois o drama da alma russa é um drama de redenção, de apaziguamento entre extremos.

Mesmo o camponês - o suposto portador da verdadeira luz cristã - não é sem contradições. Dostoiévski, como Herzen, precisa contornar o fato do comportamento imoral do camponês russo antes de atribuir-lhe um papel preponderante no destino de seu país:

${ }^{145}$ A Writer's Diary - vol. 2. Trad. Kenneth Lantz. Northwestern University Press: 1994, p. 1298. 
Então como posso reconciliar tal contradição? Mas o ponto é que ela pode ser muito facilmente reconciliada. (...) Deve-se saber segregar a beleza no camponês russo das camadas de barbarismo que se acumularam sobre ela. Ao longo de quase toda a história russa, nosso povo dedicou-se tanto à depravação, corrompeu-se e desencaminhou-se e foi tão continuamente atormentado, que é de se admirar que tenha sobrevivido preservando uma imagem humana, que dirá preservando sua beleza. (...) Não, não se julgue o povo pelo que ele é, mas pelo que ele gostaria de se tornar. Seus ideais são poderosos e sagrados; são esses ideais que preservaram nosso povo através de séculos de tormentos; esses ideais fundiram-se com a alma do povo desde tempos imemoriais e conferiram-lhe as bênçãos da franqueza, honra, sinceridade e uma mente aberta, receptiva a tudo. E, se junto a isso há tanta sujeira, então o próprio russo lamenta e acredita serem coisas extrínsecas e temporárias, ilusões do Demônio, e que um dia a escuridão terá fim e a luz eterna haverá de brilhar. ${ }^{146}$

Recordemos que Herzen justificava a imoralidade do camponês afirmando que se tratava de mera reação do povo à opressão do Estado, e que mesmo assim, no trato uns com os outros, reinava entre os habitantes das comunas camponesas a confiança e a hombridade. Dostoiévski assina embaixo de tudo isso, mas acrescenta ainda a observação de que o narod jamais toma sua imoralidade por correção; ele peca, reconhece o pecado, e segue adiante acreditando que dias melhores estão por vir.

Por um lado, Dostoiévski era, como Herzen, um crítico ferrenho das circunstâncias sociais que predispunham o povo à depravação, tais como a multiplicação de fábricas e tavernas nas grandes cidades (crítica que é evidente nas Notas de Inverno, quando o narrador analisa as consequências sociais da industrialização inglesa e francesa). Mas, por outro lado, ele rejeita

${ }^{146}$ A Writer's Diary - vol. 1. Trad. Kenneth Lantz. Northwestern University Press: 1994, pp. 347-348. 
veementemente o determinismo que considera o homem simples fruto do meio. $\mathrm{O}$ meio influencia, é claro, mas não determina terminantemente: há sempre margem para o homem escolher livremente, destacando-se de suas circunstâncias. Rejeitar o determinismo, para Dostoiévski, era complementar a sua rejeição ao ateísmo, o qual por sua vez seria apenas uma das faces do socialismo ${ }^{147}$.

E, no entanto, o romancista percebia que os tempos eram difíceis e que as circunstâncias sociais tomavam tal gravidade que o povo, sem instrução e condições básicas de existência, acabava como que privado de sua liberdade, por meio de uma espécie de entorpecimento moral. O álcool é um dos problemas que mais o preocupam nos artigos do Diário de um escritor, bem como um crescente e generalizado materialismo:

A força do povo está se esvaindo; a fonte de nossa futura riqueza está secando; seu intelecto está empobrecendo e seu desenvolvimento, retardando-se. E o que os filhos do povo de hoje trarão em seus corações e mentes, tendo crescido entre as abominações de seus pais? (...) Ou como se pode forçar alguém a ter compaixão, quando as coisas chegaram a tal ponto que é como se se erradicasse no ser humano toda a humanidade? E será só o álcool a enraivecer o narod e a corrompê-lo nesses nossos impressionantes tempos? (...) Uma espécie de inaudita corrupção de ideias instaurou-se entre o povo, junto ao ubíquo prostrar-se diante do materialismo. Chamo materialismo, nesse caso, ao prostrar-se diante do dinheiro, diante do poder do pote de ouro, (...) como se tudo que seus pais lhes ensinaram e lhes contaram até hoje não fizesse mais qualquer sentido. ${ }^{148}$

147 “O socialismo não é apenas uma questão dos operários ou do chamado quarto Estado, mas é predominantemente a questão do ateísmo, da encarnação atual do ateísmo, a questão da Torre de Babel construída precisamente sem Deus, não para alcançar o céu mas para fazer o céu descer à Terra." Digressão do narrador de Os Irmãos Karamázov no capítulo que apresenta Aliócha. Ed. 34, 2009, p. 46.

${ }^{148}$ A Writer's Diary - vol. 1, p. 329-330. 
Nas Notas de Inverno há observações semelhantes sobre as classes populares londrinas. Na década de 70, quando foram escritas as observações acima sobre o povo russo, Dostoiévski percebia o avanço, em seu país, da mesma realidade demoníaca atribuída anos antes a Londres:

Com semelhante dimensão colossal, com o orgulho titânico do espírito reinante, com o caráter acabado e triunfal das suas criações, imobiliza-se não raro a própria alma faminta, conforma-se, submete-se, procura salvação no gim e na devassidão e passa a acreditar que tudo deve ser assim mesmo. (...) Mas em Londres pode-se ver a massa humana em tal dimensão e ambiente como não se encontra em parte alguma do mundo, a não ser em sonho. (...) O povo acotovela-se nas tavernas abertas e nas ruas. Come-se e bebe-se ali mesmo. As cervejarias são enfeitadas como palácios. Tudo parece ébrio, mas sem alegria, sombrio, pesado, estranhamente silencioso. (...) Arma-se uma espécie de baile para esses escravos brancos. $^{149}$

Diz-se "realidade demoníaca" porque o "espírito reinante" aí mencionado é novamente Baal, o demônio do mundo, que com suas criações suntuosas busca hipnotizar o olhar humano, alheando-o do sentido transcendente de sua existência terrena e aferrando-o aos bens deste mundo. A cultura narodnii resistira por longo tempo às influências intelectuais do Ocidente, mas era como se nesse quarto final do séc. XIX já se tratasse de um estágio mais avançado da presença europeia na Rússia, estágio esse que já correspondia, não ao mero desejo de imitar modelos ocidentais, mas à sua real incorporação; pela primeira vez desde as reformas de Pedro I o narod encontrava-se ameaçado em sua essência, sugado pelas grandes cidades, dispersando-se da vida comunitária e camponesa que sempre assegurara sua unidade cultural.

\footnotetext{
${ }^{149}$ Notas, p. 114-115.
} 
E, no entanto, Dostoiévski lança mão de um sem número de contraexemplos para salvaguardar a liberdade de escolha do povo russo, a despeito das tão hostis circunstâncias sociais. O mujique Marei, a ama Aliena Frolovna, o soldado Fomá Danílov - são figuras camponesas que ganham destaque no Diário por representarem a "exceção exemplar", ou o melhor de que o povo russo era capaz. Dostoiévski argumenta que Fomá Danílov, por exemplo, talvez tenha vivido uma vida ordinária e até viciosa, embebedando-se e rezando menos do que deveria, e no entanto, quando chegou o momento extremo em que lhe coube dar o testemunho de sua fé cristã, não hesitou. Os ideais religiosos do povo russo, aferrados ao espírito do soldado, vieram à tona quando, capturado na Ásia Central, ele recebeu a ordem de servir ao Khan e converter-se ao Islã. Embora nenhum dos seus conterrâneos estivesse lá para presenciar seu ato heroico, o soldado teria respondido que não podia trair a cruz e que, mesmo capturado pelo inimigo, ele devia cumprir seu dever para com o Tsar e a Cristandade. ${ }^{150}$ Dostoiévski afirma que entre as classes altas um tal feito seria extraordinário, mas entre o povo, embora louvável, pertence apenas à ordem comum, pois entre o narod - insiste o romancista - há milhares como Fomá Danílov.

O drama do povo russo, a força responsável por tornar em uma coisa só os dois aspectos, vicioso e virtuoso, de seu espírito, é um drama de redenção. Há certamente muito de censurável e de verdadeiramente demoníaco em seu modo de vida, mas - Dostoiévski reitera - ao mesmo tempo há nele, como em nenhum outro povo, uma capacidade de reconhecer a baixeza dos próprios pecados, arrepender-se e sacrificar-se em busca de redenção. Dostoiévski reconhece o paradigma disso no poema Vlas, de Nikolai Niekrássov, que conta a história de uma lenda popular sobre um grande pecador que se arrepende e passa a viver em busca de expiar seus pecados. Num artigo do Diário intitulado "Vlas", a propósito do poema de Niekrássov, o

\footnotetext{
${ }^{150}$ Este feito heroico de Fomá Danílov também é relatado em Os Irmãos Karamázov.
} 
romancista polemiza com a intelligentsia liberal, a qual dizia se preocupar com as necessidades materiais e educacionais do povo, mas ridicularizava suas noções religiosas - como o próprio $\operatorname{Herzen}^{151}$.

Deste modo, Dostoiévski considera como um traço do caráter nacional de seu país, perpassando todas as classes sociais, a necessidade de descer ao inferno para buscar a luz, de negar tudo até o extremo da loucura para então, abruptamente, lançar-se na direção oposta e buscar a redenção pelo sofrimento expiatório. Desde a fase pós-Vriêmia até seus escritos no Diário, Dostoiévski estava certo de que a intelligentsia russa já vivia um momento de insuportável niilismo e, assim, a situação era favorável a um retorno à fé, à crença primeiro no ser humano, depois na imortalidade - e quem poderia ensinar aos intelectuais desnorteados o caminho de volta era o camponês, em quem se preservara a verdadeira imagem de Cristo. É claro que cabia ao intelectual ajudar o mujique a "polir-se", como a um diamante bruto; ajudá-lo a vencer a bebida, ensinar-lhe seu próprio valor. Mas, antes de tudo, era mister que o russo culto reconhecesse o valor do mujique; ainda que não chegasse a aceitar Deus - Púchkin não aceitava -, que aprendesse ao menos a praticar o amor ativo, o desprendimento de si, a devoção ao solo pátrio (pois amar a terra sofrida e maltratada onde se nasceu não deixa de ser uma lição de humildade):

"Torna-te humilde, homem soberbo; antes de tudo contém o teu orgulho. Torna-te humilde, ó homem preguiçoso; antes de tudo trabalha no teu solo nativo.” Essa é a solução de acordo com a sabedoria do Povo. “A verdade não está fora, mas dentro; encontra-te dentro de ti mesmo; submete-te a ti mesmo; domina-te, e verás a verdade. Essa verdade não a

\footnotetext{
${ }^{151}$ Ver também a resposta de Dostoiévski à crítica de Gradóvski ao “Discurso sobre Púchkin”: “O senhor sugere que a religião é uma coisa, enquanto questões sociais são outra. Seu bisturi acadêmico parte um organismo vivo e homogêneo em duas metades separadas, e o senhor afirma que essas duas metades são inteiramente independentes uma da outra." Em seguida, dedica-se à refutação desta ideia. A Writer's Diary - vol. 2, p. 1312.
} 
encontrarás nas coisas; ela não está fora de ti ou em algum lugar além do mar, mas deve encontrar-se primeiramente no teu próprio trabalho de auto-aprimoramento." 152

Uma vez que Dostoiévski acreditava piamente na alma russa e na impossibilidade de o homem russo apagar de si as marcas de sua terra natal, instar seus conterrâneos a aprender com o camponês - sua língua, seus valores, sua tradição - era não mais do que dizer-lhes que olhassem para dentro de si, não para fora; que parassem de recorrer à imitação, atentando ao que havia de mais imediato ao seu redor, pois isto constituía sua própria essência. Este é outro princípio pótchviennik recorrente também na fase madura de Dostoiévski.

Só o fato de um homem negligenciar sua própria personalidade em favor de uma de empréstimo já é negativo, mas pior ainda é quando a personalidade emprestada tem vícios muito perigosos. Dostoiévski não rejeita as ideias europeias em voga em sua época apenas pelo fato de não serem russas, mas por discordar sinceramente delas e, mais ainda, por conhecer a índole de seu povo e prever que tais ideias, germinando em solo russo, poderiam gerar frutos catastróficos. Em mais de um momento ele se refere a ideias estrangeiras que, assimiladas pelos russos, transformam-se em hipérboles deformadas. Dostoiévski, de fato, manteve até o fim da vida uma esperança cega em seu povo, em sua capacidade de reinventar-se continuamente e na humildade de quem, errando, sempre acaba reconhecendo o próprio erro e redimindo-se. Enquanto viveu, esta foi sua visão da Rússia. E em seus anos finais ele se permitiu exaltar-se ao ponto de crer, não apenas que a força do narod venceria a onda do ateísmo revolucionário em seu país, mas que a Mãe Rússia seria a luz guia entre os povos eslavos, os quais todos juntos enfrentariam o moribundo Ocidente, derrotando-o e iniciando um novo momento da História.

$\overline{{ }^{152} \text { A Writer's Diary - vol. 2, p. } 1284 .}$ 


\subsubsection{Constantinopla será nossa!}

Esta fase final do pensamento de Dostoiévski, a qual podemos chamar de pan-eslavista, expressa-se sobretudo nos textos do Diário de um escritor. Nas Notas de Inverno, como vimos, a ideia do exclusivismo russo já é mencionada explicitamente, mas é no Diário, alguns anos depois, que Dostoiévski a explora em detalhes, permitindo-nos saber com mais clareza em que medida há implicações políticas e imperialistas em sua exaltação da preponderância dos valores tradicionais russos sobre os do Ocidente.

Ao fim da vida, Dostoiévski parece ter sentido grande necessidade de esclarecer suas ideias, provavelmente percebendo que a polifonia de seus romances roubava a cena de suas convicções pessoais. Uma das evidências disso diz respeito ao "Discurso sobre Púchkin", proferido pelo escritor em 8 de junho de 1880, meses antes de sua morte, em uma solenidade da Sociedade dos Amantes da Literatura Russa. Já sendo o próprio discurso uma síntese geral das ideias político-culturais do romancista, ainda assim sua versão impressa no Diário foi precedida por uma longa "Nota Explanatória A Respeito do Discurso Sobre Púchkin Impresso A Seguir", na qual Dostoiévski "mastiga" previamente os principais pontos do discurso, prevendo algumas objeções ao seu conteúdo. Mas, como não fosse suficiente, fez incluir também um post-scriptum mais longo ainda, na forma de "Quatro Lições Sobre Vários Tópicos A Propósito de Uma Lição Que Me Foi Dada Pelo Sr. A. Gradóvski", onde as mesmas ideias discutidas na "Nota Explanatória" e no "Discurso" são abordadas por novos ângulos.

É bastante conhecida a recepção calorosa com que o público da Sociedade dos Amigos da Literatura Russa recebeu o "Discurso Sobre Púchkin". Há relatos sobre o êxtase a que as palavras de Dostoiévski levaram seus ouvintes, com direito a muitos minutos de aplausos 
cerrados, lágrimas e inimigos abraçando-se em reconciliação. Contudo, não é de surpreender ao menos quando se trata da intelligentsia russa - que já desde o dia seguinte à palestra tenham começado a despontar vozes discordantes, e que mesmo alguns dos entusiastas do dia anterior tenham voltado atrás em sua aceitação extática das palavras de Dostoiévski.

Uma dessas vozes discordantes foi a de Gradóvski, e segundo o próprio Dostoiévski ele sintetizava todas as demais. Por este motivo, o romancista fez parar a impressão da edição do Diário onde seriam publicados o "Discurso Sobre Púchkin" e a "Nota Explanatória” para aporlhe uma longa resposta a Gradóvski - as mencionadas "Quatro Lições Sobre Vários Tópicos”. Nesta edição do Diário, Dostoiévski declara seu desejo de que estes textos sejam sua "profissão de fé”, a síntese das muitas possíveis sínteses de seu pensamento. Com efeito, há neles algumas de suas reflexões mais instigantes sobre questões históricas, culturais e políticas, depondo contra certas visões de Dostoiévski (notadamente, a de Nikolai Strákhov após o rompimento entre ambos) descrevendo-o como um homem inculto, um poeta semilouco, inspirado mais pelo calor do momento do que por estudos sérios.

Na resposta a Gradóvski, para chegar à afirmação de que a Rússia deve tomar Constantinopla e libertar o Ocidente de seus erros, Dostoiévski parte de uma reflexão sobre a relação entre ideais morais e ideais cívicos, desenvolvendo aquela que já mencionamos como sua ideia seminal: a ideia de que o aprimoramento moral dos indivíduos deve coincidir com sua conformação gradual à humildade cristã e ao amor ao próximo, e de que uma ordem social perfeita será necessariamente o produto do aprimoramento individual nesses termos.

Dostoiévski opõe esta ideia a outra, muito em voga desde sua época, segundo a qual o bem social só é possível após haver instituições cívicas adequadas - por exemplo, uma república em que, supostamente, a divisão igualitária de bens materiais e direitos civis entre os homens 
permitiria, enfim, sua convivência em concórdia. Gradóvski, um dos expoentes desta última visão, em seu artigo contra o "Discurso Sobre Púchkin”, declara: "Com estas palavras [sobre a necessidade de o homem tornar-se humilde] o Sr. Dostoiévski expressou a mais sagrada de suas convicções. Tais palavras contêm um grande ideal religioso, uma poderosa homilia sobre

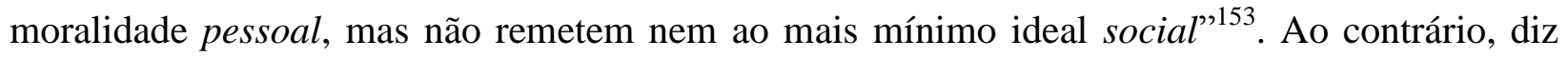
Dostoiévski, são os ideais morais que tornam possíveis os ideais cívicos; o aparato cívico de um povo surge a partir do momento em que ele estabelece-se enquanto povo em torno de um ideal moral:

Como você pode unir pessoas para alcançar objetivos cívicos se não tem como base uma poderosa e fundamental ideia moral? E ideias morais são sempre as mesmas: todas baseiam-se na ideia do aprimoramento pessoal absoluto no futuro; pois esta ideia contém em si tudo, todas as aspirações e desejos humanos; assim, Sr. Gradóvski, todos os seus ideais cívicos emergem dela. (...)

$\mathrm{Na}$ origem de todos os povos e nacionalidades, a ideia moral sempre precedeu a gênese da nacionalidade ela mesma, pois tal ideia é a força criadora da nacionalidade. [Grifo de Dostoiévski] Esta ideia moral, por sua vez, sempre emergiu de algumas ideias místicas, da convicção de que os homens são eternos, de que não são simplesmente animais vagando pela terra, mas estão ligados a outros mundos e à eternidade. Sempre e em todo lugar tal convicção

\footnotetext{
${ }^{153}$ Diz ainda Gradóvski: “O Sr. Dostoiévski nos insta a desenvolvermos nossa humildade. O aprimoramento pessoal no espírito do amor cristão é, sem dúvida, o primeiro pré-requisito para qualquer atividade, grande ou pequena. Mas daí não se segue que pessoas as quais tenham pessoalmente se tornado perfeitas em sentido cristão necessariamente formariam uma sociedade perfeita. [Dostoiévski marca esta última frase com um sinal de "?!", indicando considerá-la absurda.] (...) Moralidade pessoal e social não são a mesma coisa. Disto se segue que nenhum aprimoramento social pode ser realizado apenas pela melhoria das qualidades pessoais do povo que compõe uma sociedade. (...) O aprimoramento de um povo em sentido social não pode ser feito apenas através do trabalho "dos homens em si mesmos" e através de "humilhar-se". Um homem pode trabalhar em si mesmo e controlar suas paixões em uma ilha deserta, mas enquanto criaturas sociais as pessoas se desenvolvem e se aprimoram no trabalho umas para as outras e umas com as outras. Este é o motivo pelo qual o aprimoramento social do povo depende em tão larga medida do aprimoramento de instituições sociais que desenvolvam, se não suas virtudes cristãs, suas virtudes cívicas." In: A Writer's Diary, vol. 2, p. 1312-1313.
} 
formulou-se em religiões, na confissão de alguma nova ideia; e sempre, assim que nascia uma nova religião, uma nova nacionalidade era subitamente criada em nível cívico. Veja os judeus e os muçulmanos. (...) Para preservar o tesouro espiritual que recebeu [pela revelação religiosa] é que um povo se une; e apenas então, com zelo e ansiedade, trabalhando umas com as outras e umas para as outras, é que as pessoas começam a procurar modos de se organizar, buscando alguma fórmula cívica para a vida em comum, a qual as ajude a transmitir ao mundo a completa glória daquele tesouro moral que receberam. E note que, com a passagem de séculos e eras, assim que a ideia espiritual de uma nacionalidade começa a dispersar-se e enfraquecer, a própria nacionalidade também entra em declínio, e com ela todos os seus preceitos cívicos; todas as ideias cívicas nas quais o povo havia logrado firmar sua nacionalidade desaparecem. As formas que a religião assume entre um povo determinam o modo como seu sistema cívico estabelece-se. Assim, ideais cívicos estão sempre direta e organicamente vinculados aos ideais morais; o que é mais importante, aqueles derivam sempre e exclusivamente destes.

Vê-se, portanto, que para Dostoiévski a ideia de aprimoramento pessoal tinha íntimo vínculo com a intuição que os homens têm de sua imortalidade. O raciocínio proposto diz que todas as religiões têm por base uma ideia moral e que todas as ideias morais têm o mesmo objetivo: o aprimoramento individual absoluto, com o retorno do homem ao seu verdadeiro tamanho, muito maior do que sua presente versão terrena e transitória. Dostoiévski neste trecho dá a entender que todas as religiões comungam da mesma intuição básica, relativa à imortalidade da alma humana, mas sabemos, por outros escritos seus, que ele considerava a ideia moral cristã - personificada pelo Cristo vivo e ressuscitado - superior a todas as outras. Retornemos, por exemplo, ao excerto do caderno de notas de Dostoiévski, de 1864, citado anteriormente: 
Após o aparecimento de Cristo enquanto o ideal de homem encarnado, tornou-se claro como o dia que o desenvolvimento final e mais alto da personalidade coincide com o ponto no qual o homem descobre, sabe e acredita com toda a força de sua natureza que o supremo uso que pode fazer de sua personalidade, da inteireza do desenvolvimento de seu ego, é eliminar este ego, entregá-lo de todo o coração e desinteressadamente. E esta é a maior das felicidades. Deste modo, a lei do ego une-se à lei do humanismo e, nesse entrelaçamento, o ego e a coletividade aniquilam-se mutuamente, ao mesmo tempo em que cada um alcança a seu modo o ápice de seu desenvolvimento individual.

Este é o paraíso de Cristo. Toda a história da humanidade é apenas o desenvolvimento, o embate, a aspiração ao cumprimento deste objetivo. ${ }^{154}$

Ou seja, ainda que todas as religiões nasçam da intuição de que o homem deve aprimorarse para conformar-se ao Bem Absoluto, é com o advento de Cristo que este Bem personifica-se e se dá a conhecer em carne e osso, e portanto toda "ideia moral" que O exclua está em falta com a verdade. A extrema abnegação de Cristo e o exemplo de seu amor ativo são a única base sobre a qual, segundo Dostoiévski, podem erigir-se instituições cívicas sólidas. O princípio do "cada um por si”, da felicidade imediata e dos desejos irrefreáveis, no qual consistia toda a lei moral no Ocidente, podia erigir, no máximo, a Torre de Babel natimorta que, revolução após revolução, a Europa tentara erguer em lugar do Paraíso de Cristo.

Esta síntese última que o próprio Dostoiévski nos oferece de seu pensamento não deixa dúvidas de que, em sua fase final, suas ideias recendem ao mais puro Eslavofilismo. O critério utilizado para diferenciar o Oriente russo do Ocidente europeu é um critério religioso: a civilização europeia perdera a "ideia moral" sobre a qual se erigira; o Papa, tomando a espada das mãos de César, secularizara a Igreja de Roma e, com isso, todos os valores cívicos do

\footnotetext{
${ }^{154}$ Dostoiévski, “Neizdannyi Dostoevskii”, p. 173.
} 
Ocidente, organicamente dependentes da força dos valores morais cristãos, desapareceram como fumaça, deixando em seu lugar apenas seus opostos: o materialismo, o egoísmo, o ateísmo, valores sobre os quais era impossível construir a fraternidade autêntica, mas apenas a tirania travestida de fraternidade oferecida pelo socialismo.

Entre os povos eslavos, porém, a ideia moral cristã seguia viva. Se grande parte da intelligentsia eslava fora "contaminada" pela doença ocidental, o povo simples, espontaneamente organizado em comunidades politicamente descentralizadas, ainda era animado pelo mesmo espírito fraterno dos primeiros séculos de Cristianismo. Para sustentar esta afirmação, Dostoiévski oferece uma peculiar leitura da História:

[Durante os primeiros séculos de Cristianismo] houve uma colisão entre as duas ideias mais completamente opostas que poderiam existir sobre a terra: o homem-deus encontrou o Deus-homem; Apollo Belvedere encontrou Cristo. Um compromisso foi firmado: o império aceitou a Cristandade, enquanto a Igreja aceitou a lei e o Estado romanos. Uma pequena parte da Igreja fugiu para regiões remotas e continuou seu trabalho anterior: novamente surgiram comunidades cristãs, e em seguida monastérios - mas tudo eram meros experimentos; e deste modo continuou até nossos dias. A parte restante e dominante da Igreja subsequentemente dividiu-se em duas metades, como todos sabemos. Na metade ocidental, o Estado enfim subjugou a igreja, a qual desapareceu e reencarnou de uma vez por todas enquanto Estado. O papado instaurou-se - a continuação do antigo Império Romano em nova encarnação. Na metade oriental, contudo, o Estado foi conquistado e destruído pela espada de Maomé, e apenas Cristo restou. Mas este Estado que aceitou e uma vez mais elevou Cristo tem sofrido penas terríveis ao longo dos séculos, impingidas por seus inimigos, pelos tártaros, por suas próprias desordens, pela servidão, pela Europa e o europeanismo; e até hoje ainda 
enfrenta tanto sofrimento que uma fórmula social genuína, de acordo com o espírito do amor e o aprimoramento pessoal cristão, ainda não chegou realmente a ser elaborado dentro dele. ${ }^{155}$

Este trecho evidencia a simpatia de Dostoiévski pelos Velhos Crentes e demais dissidentes da Ortodoxia Oficial. Ele afirma com todas as letras que o espírito original da Igreja cristã foi levado adiante pela pequena parte que "fugiu para regiões remotas", enquanto a porção restante dividiu-se em duas metades - as Igrejas Católica Romana e Ortodoxa. O mais natural, seguindo esta linha de pensamento, seria Dostoiévski centrar suas esperanças nesses grupos dissidentes, acusando cesaropapismo em ambas as metades oficiais da Igreja. Porém, o Dostoiévski pan-eslavista tem de ser necessariamente tsarista, e assim sua leitura do processo histórico perde em coerência. Os Velhos Crentes, expoentes do "genuíno Cristianismo" segundo indicação do próprio romancista, eram perseguidos pelo Estado russo; ainda assim, Dostoiévski afirma - caindo em contradição - que este Estado "aceitava e exaltava Cristo" e que, à força de sua história de opressão por povos invasores e inimigos variados, unira-se com força ainda maior em torno de sua ideia moral cristã ${ }^{156}$.

Em seguida, o passo final para a construção do argumento pan-eslavista tipicamente russo de Dostoiévski é declarar que não haveria de ser por acaso que os povos eslavos, tão humildes quanto fervorosos na defesa de sua ideia original, podiam contar com a Rússia, este Estado de dimensões continentais, o qual nos últimos anos ganhara a maturidade necessária para abraçar a missão sagrada de liderar todo o mundo eslavo em uma cruzada do "verdadeiro Cristianismo" contra o "anti-Cristianismo materialista do Ocidente".

\footnotetext{
${ }^{155}$ A Writer's Diary, vol. 2, p. 1322.

${ }^{156}$ Há ainda a possibilidade de o escritor ter adaptado à censura tsarista a expressão de suas reais convicções. Não fosse pela censura, ele declararia abertamente sua simpatia pelas seitas ditas heréticas da Ortodoxia? É bastante possível. Ainda assim, sua exaltação do Estado tsarista, nessa fase final de seu pensamento, parece sincera e é uma necessidade de seu pan-eslavismo.
} 


\section{Diz Dostoiévski no "Discurso Sobre Púchkin":}

Sim, é incontestável que a vocação do homem russo é unir a Europa e o mundo todo. Ser um verdadeiro russo pode significar e significa apenas (no fim das contas, isso deve ser sublinhado) tornar-se irmão de todos os homens, um homem universal, por assim dizer. (...) Acredito que, posteriormente, nós, ou seja, não nós, é claro, mas os futuros russos, entenderão exatamente tudo o que significa ser um russo de verdade: tentar trazer a reconciliação final para as contradições da Europa, indicar uma saída para a angústia europeia em sua alma russa, que reunifica toda a humanidade, incorporar nela, com amor fraternal, todos os nossos irmãos e, no fim, eventualmente, talvez, proferir a última palavra da grande harmonia geral, do acordo fraternal de todas as raças segundo a lei do Evangelho de Cristo! $!^{157}$

Até aqui, porém, não é possível divisar com clareza o quanto há de pretensões imperialistas nas esperanças de Dostoiévski para o papel de seu país junto aos povos eslavos e ao Ocidente. $\mathrm{O}$ fato é que ele nunca chegou a formular suas expectativas políticas na exortação de um plano de ação para concretizá-las. Há artigos afirmando a inevitabilidade da tomada de Constantinopla pela Rússia, mas o romancista não vai muito além da afirmação categórica desta inevitabilidade. Tudo o que ele oferece é uma argumentação baseada na "coerência histórica" da liderança, pela Rússia, da dita Questão Eslava. Dostoiévski, como Herzen, foi menos um ativista político do que um teórico da História. Ele não parecia ter a intenção de influenciar a política de seu país para além da esfera de influência de seus textos, e, à diferença de Herzen, como vimos, foi constante em sua crítica severa a qualquer mudança social que não decorresse de um processo gradativo e antes de tudo moral e cultural da sociedade.

${ }^{157}$ In: "Púchkin". Antologia do Pensamento Crítico Russo (1802-1901). Org. Bruno Barreto Gomide. São Paulo, Ed. 34: 2013, p. 422. 
Nada disso, porém, permite-nos afirmar que Dostoiévski não esperava, concretamente, que a Rússia exercesse domínio político sobre os demais povos eslavos e que no futuro tomasse a dianteira político-cultural do mundo, em lugar da Europa. Embora em alguns artigos ele se empenhe em suavizar o tom imperialista de seu discurso, este tom ocorre com frequência em vários de seus textos. Por exemplo:

Mas em nome de qual direito moral poderia a Rússia reivindicar Constantinopla? Qual motivo superior nós poderíamos usar para demandá-la da Europa? Precisamente este motivo superior: o fato de a Rússia ser líder da Ortodoxia, sua protetora e guardiã, papel este estabelecido para ela desde Ivan III, que colocou como um emblema a águia de duas cabeças de Tsargrado sobre o antigo escudo de armas da Rússia; este papel, porém, só foi claramente revelado após Pedro, o Grande, quando a Rússia percebeu que estava em seu poder cumprir esta missão e de fato tornou-se a verdadeira e única guardiã tanto da Ortodoxia quanto das nações que a professam. Esta é nossa razão e direito à antiga Tsargrado, direito o qual seria óbvio e inofensivo mesmo aos Eslavos mais ciosos de sua independência, ou mesmo aos gregos. $^{158}$

Trechos como esse ocorrem com frequência no Diário, ao lado de análises sobre diversas questões políticas em curso naquele momento, as quais pareciam ser o foco de atenção de Dostoiévski. Assim, o Diário como um todo - e sua versão literária dada nos grandes romances, notadamente em Os Irmãos Karamázov - nos leva a crer que, apesar de não traçar ele mesmo um plano de dominação política dos povos eslavos pela Rússia, Dostoiévski estava inteiramente aberto à execução desta ideia, por mais contraditório que isto seja com sua constante exortação à liberdade individual e à independência dos povos.

\footnotetext{
${ }^{158}$ A Writer's Diary, vol. 2, p. 890-891.
} 
Tal conclusão vai de encontro à apresentada por Ellis Sandoz em seu importante livro sobre "O Grande Inquisidor":

Por mais poderosos que sejam os elementos de escatologia apocalíptica na obra de Dostoiévski, eles apenas simbolizam a esperança na redenção espiritual do homem por meio da Graça, emblemática do horizonte aberto evocado por sua filosofia do homem e da história; mas eles não atingem o objetivo de um concreto programa de ativismo político. Com isso não se quer dizer que Dostoiévski não desejasse poder político e mesmo sucesso imperial para a Rússia. Mas o uso de poder e coerção, compreendido enquanto próprio da esfera política, era impensável para Dostoiévski enquanto instrumento para alcançar o Millennium. Se a "Lenda do Grande Inquisidor” tem algum significado, terá no mínimo este. ${ }^{159}$

De fato, “o uso de poder e coerção, compreendido enquanto próprio da esfera política," opõe-se frontalmente ao significado da "Lenda do Grande Inquisidor". Contudo, como já assinalamos anteriormente, Dostoiévski era um escritor cindido entre uma percepção aguda da realidade e sentimentos de um nacionalismo xenófobo. Sua exortação do exclusivismo russo, com implicações políticas e imperialistas evidentes, contradiz a verdade desenhada com traços de gênio em suas grandes obras.

Fazendo um esforço para sistematizar a visão de Dostoiévski sobre a "ascensão da Estrela Oriental", pode-se dizer que ele supunha um movimento em duas partes: primeiro, a unificação dos eslavos sob a "proteção" da Rússia - o que só seria possível em nível político-cívico após a preparação moral do mundo eslavo, o qual deveria abraçar os valores tradicionais de seu povo genuinamente cristão e tomar consciência de sua missão histórica na defesa da Ortodoxia contra

${ }^{159}$ SANDOZ, Ellis. Political Apocalypse: a study on Dostoevsky's Grand Inquisitor. ISI Books: 2000, p. 233 e 235. 
o Cristianismo herético do Ocidente (expresso tanto pelo catolicismo quanto pelo socialismo); em seguida, o mundo eslavo reunido sob as asas da águia de duas cabeças de Tsargrado passaria ao combate propriamente dito contra as ruínas da civilização ocidental, libertando-a de seus próprios erros e ensinando-lhe o caminho verdadeiro, isto é, ortodoxo. Aqui, fica em aberto se Dostoiévski visualizava um combate físico ou apenas cultural; decerto, a tomada de uma cidade importante como Constantinopla não poderia se dar de forma pacífica, mas o escritor não entra em detalhes nesse ponto. Em um dos artigos do Diário que lidam mais diretamente com essa questão, ele apresenta, como de costume, uma análise histórica e conclui pela inevitabilidade da liderança russa sobre o mundo eslavo e da "colisão" deste com a Europa, sem contudo especificar a natureza desta colisão:

Não podemos de modo algum abandonar ou enfraquecer o nível de nossa longeva participação nesta grande questão [eslava]. Não é apenas o porto magnífico [de Constantinopla] e o acesso a mares e oceanos que une a Rússia tão intimamente à resolução dos destinos desta questão fatídica, nem mesmo é a unificação e regeneração dos Eslavos... Nosso objetivo é imensuravelmente mais profundo. Nós, Rússia, somos verdadeiramente essenciais e inevitáveis tanto para toda a Cristandade Oriental quanto para o destino e unidade da futura Ortodoxia sobre a terra. É isto o que nosso Povo e seus governantes sempre compreenderam... Em suma, esta terrível Questão Eslava é virtualmente todo o nosso destino ainda por muitos anos. Ela contém como que todos os nossos objetivos e, sobretudo, nosso único modo de emergir à totalidade da história. Ela contém ainda nossa colisão final com a Europa e nossa união final com ela, mas desta vez sob princípios novos, poderosos e produtivos. (...) Enfim, qualquer que seja o resultado dos atuais e, talvez, essenciais acordos diplomáticos e discussões em curso na Europa, cedo ou tarde Constantinopla será nossa 
[ênfase de Dostoiévski], mesmo que apenas no próximo século! Isto nós russos devemos ter em mente sempre, continuamente. ${ }^{160}$

Estas são as linhas gerais da utopia nacional-populista dostoievskiana. Para matizá-la, recorramos uma vez mais à comparação com Herzen, cujas semelhanças e diferenças com relação a Dostoiévski ajudam a compor o quadro geral do messianismo russo, do qual se falou no início deste trabalho.

${ }^{160}$ A Writer's Diary, vol 2., p. 900. 


\section{CONCLUSÃO:}

\section{Na Encruzilhada da História}

Comparando o nacional-populismo de Dostoiévski e Herzen, uma primeira diferença fundamental vem à tona: o pensamento de Herzen é absolutamente secular, isto é, ocupa-se de questões práticas, de cunho social e político, por motivações igualmente concretas e imediatas (p.ex., a necessidade de haver distribuição igualitária de bens materiais entre os homens); seu elogio do narod russo é feito na medida em que este pode servir àquelas questões, e só. Já Dostoiévski põe seu foco principal nos problemas ditos do espírito: seu combate não é diretamente contra o modelo econômico capitalista ou socialista, e sua proposta de solução aos problemas russos e ocidentais não é a organização social da comuna camponesa russa - como em Herzen; a preocupação de Dostoiévski é antes de tudo com reestabelecer a "ideia moral" que em seu entendimento deu origem tanto à civilização ocidental quanto à russa, pois antes disto ser feito nenhum "ideal cívico" pode ser concebido.

Paralelamente a esta primeira divergência de base, encontra-se a semelhança fulcral entre os dois autores: Dostoiévski e Herzen, como bons filhos de seu século, construíram o edifício de seus ideais sociopolíticos sobre uma visão idealizada do "povo" - fosse o povo russo (narod) ou o povo em geral, aí inclusas todas as classes de trabalhadores braçais, de camponeses a proletários. O ideal de Dostoiévski tem como protagonista especificamente o povo russo; já Herzen tende a idealizar as classes populares de todos os países que visita. Ambos, porém, partilham da visão de que o "povo" é uma massa coesa e profundamente intuitiva e instintiva: o que não sabe por meio de livros, aprende por experiência. Precisamente o mesmo que diz 
Dostoiévski sobre o "Cristianismo intuitivo" do narod, o qual prescinde de catecismos e livros religiosos, Herzen diz sobre o potencial revolucionário dos proletários europeus:

O povo, como as mulheres, entende as coisas por meio de um processo especial e um tato especialmente desenvolvido; nós elaboramos um longo esforço teórico diante dele, mas eis que de repente ele o compreende por inteiro e, aparentemente, sem esforçar-se. Uma nova verdade que o cative, se ele a compreende, não ocupa sua razão, mas o leva à ação imediata. (...)

Uma pesada tempestade está surgindo no coração do camponês. Ele não sabe nada sobre o texto da constituição, nem sobre a divisão de poderes, mas olha carrancudo para o rico proprietário, para o tabelião, para o usurário; ele vê que não importa o quanto você trabalhe, o lucro vai para outras mãos - e então ele ouve o que diz o proletário. Uma vez que ele o ouviu e entendeu bem, com sua firmeza teimosa de trabalhador braçal, com sua solidez fundamental em cada ação, ele mensurará sua força e então lavará a velha estrutura social da face da terra. E esta será a real revolução das massas populares. É mais do que provável que o verdadeiro combate entre a minoria rica e a maioria pobre tenha um forte caráter comunista. $^{161}$

Estas palavras constam da décima terceira das Cartas de França e Itália. Herzen ainda residia em Nice, mas suas esperanças em uma revolução política nos moldes de 1848 já estavam devastadas. Não é sem apreensão que ele prevê o "levante comunista" que acredita iminente. Ele outrora nutrira esperanças de participar do processo que eliminaria o "velho mundo" e o substituiria por um melhor e mais justo; mas durante o próprio esforço participativo percebeu que um homem não pode eliminar-se e renascer ao mesmo tempo, e assim sua previsão da

${ }^{161}$ Cartas, pp. $187-188$. 
iminência de um levante popular comunista recende à alegria melancólica de quem anuncia uma festa para a qual não foi convidado. Ele diz, ainda na décima terceira carta:

Não importa o quanto nos rebelemos, o quanto nos enraiveçamos, ainda assim nós pertencemos em vida, hábito e linguagem àquele mesmo ambiente literário, acadêmico e político o qual rejeitamos. (...) O povo não precisa do que podemos e desejamos dizer; nossas palavras são respostas, tribunas, a elaboração de nossos conceitos. O povo mal conhece as aparições contra as quais lutamos, nossa luta não lhe diz respeito. (...) Quem quer que se sinta tão próximo do povo, tão independente da civilização artificial e que tenha acabado consigo mesmo ao ponto de poder dedicar-se inteiramente à ação, a esta pessoa cabe a voz para falar com o povo.

Vocês sentem algo assim em seus corações? Eu duvido. Nós somos ao mesmo tempo os cadáveres e os assassinos, a doença e o anatomista do velho mundo. ${ }^{162}$

É evidente que Herzen julga toda a intelligentsia por sua experiência pessoal. Ainda assim, tais palavras apontam para a distância real que havia entre as classes populares e esta mesma intelligentsia. Esta tendência a ver o "povo" como uma massa coesa, cuja vontade é única e influenciável por ideias prontas que traduzam sua intuição bruta da realidade, foi expressa igualmente por Dostoiévski e Herzen, entre vários outros autores contemporâneos, inclusive - e notadamente - Marx, configurando portanto uma tendência intelectual da época. Por trás de tal tendência pode-se divisar uma visão distanciada e pouco diferenciada do povo, o qual, no discurso de todos esses autores, acaba recebendo um tratamento que corresponde a “aquilo o que nós não somos", como uma tabula rasa na qual os intelectuais inscrevem suas melhores esperanças. No cenário russo do século XIX, o fato de que tantas distintas ideologias

${ }^{162}$ Cartas, pp. 190-191. 
tenham conseguido cooptar a imagem do mujique às suas diversas causas aponta para o mesmo distanciamento. O próprio Dostoiévski, afirmando-se um profundo conhecedor do narod pelo fato de ter coabitado por vários anos com presos siberianos, incorre nas mesmas generalizações grosseiras ao projetar sobre os camponeses seus ideais eslavófilos.

Herzen, no momento conturbado e pessimista de sua vida ao qual corresponde o fim das Cartas de França e Itália, expressa com todas as letras o quanto "o povo" lhe é estranho. E anuncia o prospecto de uma "revolução comunista", isto é, deflagrada por uma horda camponesa e proletária fora de controle, com uma espécie de acidez suicida; não é a revolução pela qual ele tanto lutara, mas é a única que então lhe parece possível. Significativamente, a décima quarta carta, a penúltima do ciclo, é aberta com a frase "Vive la mort, amigos." E nela Herzen desenha sua visão para o futuro catastrófico da Europa:

Bárbara e violentamente, uma nova civilização apossa-se do solo antigo ou aparta-se dele, se este solo estiver improdutivo e exausto. É a desordem de um funeral. (...)

Toda a Europa será levada à devastação geral; as fronteiras dos países mudarão, os povos se unirão em diferentes grupos, nacionalidades serão corrompidas e assaltadas. As cidades, saqueadas e castigadas por tempestades, empobrecerão, a educação entrará em colapso, as fábricas pararão; o campo estará deserto, a terra estará destituída de mãos, como depois da Guerra dos Trinta Anos; o povo exaurido submeter-se-á a tudo, o despotismo militar substituirá toda a legalidade e toda a administração. (...) E aqui - no extremo da destruição e da calamidade - outra guerra, dessa vez doméstica, terá início: a represália dos destituídos contra os proprietários!

Não adianta dar de ombros, enraivecer-se e xingar. Romieu não previu tudo isto? “Ou o cesarismo desesperado, ou o fantasma vermelho". (...) O proletário medirá pela mesma régua com que foi medido. $\mathrm{O}$ comunismo se alastrará tempestuosa, horrível e 
sanguinariamente, injusto e rápido. Em meio aos raios e trovões e ao brilho de palácios em chamas, nas ruínas das fábricas novos mandamentos aparecerão, as características fortemente aferradas de um novo símbolo de fé. (...)

Vocês sentem pela civilização?

Eu também sinto.

Mas as massas, às quais ela não deu nada exceto lágrimas e ignorância, nada sentem. Humildade diante do destino irreversível! ${ }^{163}$

Este trecho nos leva à análise de outro ponto interessante do pensamento dos dois autores aqui comparados: sua eficácia enquanto leitores do processo histórico no que diz respeito às ideias e revoluções políticas. O fato de ambos vaticinarem o declínio irreversível da civilização ocidental e seu iminente assalto por instituições (segundo Herzen) ou valores (segundo Dostoiévski) russos já os afasta em igual medida do quadro verídico desenhado pela história do século passado até o momento presente. Ainda assim, em suas previsões imprecisas - e delirantes, em certos aspectos -, cada qual teve sua margem de erro e acerto. Mais do que checar o "dom de profecia" de ambos, cotejar suas expectativas com a realidade (na medida em que a ciência histórica tem sido eficaz em descrevê-la) pode oferecer-nos algumas importantes lições.

Dostoiévski, no Diário de um escritor, quase trinta anos após Herzen profetizar o cataclismo europeu, pinta um quadro muito semelhante para o futuro da Europa:

A conta final e o acerto da balança podem acontecer muito antes do que as mais delirantes fantasias predizem. Os sintomas não são bons. A situação política antinatural dos Estados europeus pode servir de estopim para tudo. Uma pequena parte da humanidade não pode possuir todo o resto como escravos, e no entanto foi exclusivamente com este objetivo

\footnotetext{
${ }^{163}$ Cartas, pp. 194-199.
} 
que, até hoje, todas as instituições cívicas (as quais há muito deixaram de ser cristãs e são hoje inteiramente pagãs) da Europa foram criadas. Esta antinaturalidade e estas questões políticas "insolúveis" devem infalivelmente levar a uma enorme e derradeira guerra de partição na qual todos estarão envolvidos e a qual estourará neste século, talvez mesmo na próxima década. (...)

E eis que os proletários saem às ruas. O que vocês acham: eles agora esperarão pacientemente como antes, morrendo de fome? Isto será possível, uma vez que temos o socialismo político, depois da Internacional, dos congressos sociais e da Comuna de Paris? Não, agora as coisas não mais serão como antes: os proletários varrerão a Europa e toda a velha ordem colapsará de uma vez por todas. ${ }^{164}$

Os fatos previstos por Dostoiévski são essencialmente os mesmos da projeção de Herzen: a situação político-econômica da Europa, insustentável a longo prazo, culminará primeiro em uma grande guerra internacional que desorganizará os Estados europeus; então, em meio à balbúrdia geral, guerras domésticas eclodirão, com os proletários das grandes potências industriais tomando as ruas e concluindo a destruição do "velho mundo".

Nem Herzen nem Dostoiévski viam inteiramente com bons olhos este panorama. A diferença é que Dostoiévski opunha-se a ele em princípio, desde suas premissas teóricas até suas consequências práticas, ao passo em que a discordância de Herzen diz mais respeito à metodologia de uma revolução "descontrolada" do que ao fato em si de se destruir a velha ordem por meio de um levante popular. Isto é, a onda proletária desfigurando a face do continente europeu era quase a revolução idealizada por Herzen; para Dostoiévski, era em todos os sentidos uma ameaça nefasta e um pesadelo.

${ }^{164}$ A Writer's Diary, vol. 2, pp. 1320-1321. "Four Lectures On Various Topics". 
E é sobre a perspectiva desta ameaça que Dostoiévski constrói seu edifício utópico. O papel da Rússia enquanto retificadora dos erros do Ocidente viria à tona, segundo o romancista, na esteira da desordem revolucionária europeia:

As ondas [da revolução proletária] quebrarão inofensivas apenas contra as nossas margens [russas], pois apenas então, claramente e para todos verem, virá a total revelação de quão distinto é o nosso organismo do organismo europeu. Então, mesmo vocês, pensadores doutrinários, talvez recobrem os sentidos e comecem a buscar em nossa pátria "os princípios do Povo", dos quais vocês até agora apenas riem. E ainda assim, hoje, os senhores apontam para a Europa e nos instam a transplantar para cá aquelas mesmas instituições as quais entrarão em colapso por lá amanhã. (...) “Eles há muito resolveram seus problemas”, o senhor diz - e isto após vinte constituições em menos de um século e quase dez revoluções! Oh, talvez apenas então, livres da Europa por um momento, nós nos aproximaremos de nossos próprios ideais sociais, aqueles inequivocamente derivados de Cristo e do aprimoramento pessoal, Sr. Gradóvski. ${ }^{165}$

Entre as previsões de Herzen e Dostoiévski há, portanto, uma semelhança particularmente significativa: ambos visualizavam a revolução proletária acontecendo na Europa. Dostoiévski via na Rússia o “antídoto" à onda revolucionária; Herzen limitava-se a inspirar-se em sua terra natal para propor uma revolução socialista mais limpa e gradualista, com os avanços tecnológicos ocidentais aliados ao modelo social da comuna camponesa russa. Ambos consideravam que a difusão das ideias socialistas, originalmente europeias, já estava adiantada na Rússia, porém não lhes ocorria a possibilidade de as condições imediatas de sua terra natal serem mais propícias à revolução do que no Ocidente.

${ }^{165}$ Idem, p. 1321. 
Enfim, eis que a grande guerra internacional de fato eclodiu, e os anos de 1914-18 realmente mudaram o mapa da Europa, desfigurando nacionalidades e fronteiras; e, o que é mais importante, a guerra criou, com efeito, a ocasião para a revolução socialista - na Rússia. Neste ponto o século XX foi uma resposta um tanto cruel e irônica às esperanças eslavófilas de Dostoiévski. O paradigma do poema Vlas, de Niekrássov, do pecador que na hora H se converte e passa a viver para expiar suas faltas, não descrevia, afinal, o eterno movimento da alma russa, como o romancista queria crer. O miserável e religioso povo russo não conteve a revolução; pelo contrário, serviu-lhe de substrato material. À altura da guerra civil, ambos os exércitos branco e vermelho eram compostos por camponeses ${ }^{166}$.

Se em certo sentido é legítimo dizer que a revolução socialista na Rússia expressou a vontade de seu povo, da mesma forma, diante dos relatos históricos sobre os variados destinos de famílias e grupos camponeses durante os anos revolucionários, é difícil atribuir a uma entidade abstrata chamada "povo" uma única vontade e um único destino. Ao que tudo indica, o principal traço comum entre as classes populares russas na virada do século XIX para o XX não era nem seu Cristianismo "puro", nem seu tino político naturalmente aguçado, mas o alheamento com relação aos afazeres da nobreza e da intelligentsia. Assim, deflagrada a revolução, houve grupos populares que voluntariamente a abraçaram, como houve os que a rejeitaram, mas a grande maioria quedou indefesa e atônita sob as engrenagens do momento crítico.

Olhando retrospectivamente, Dostoiévski e os pótchvienniki estavam no caminho certo ao aliar a exaltação dos valores populares tradicionais à necessidade da educação do narod; afinal,

\footnotetext{
166 “Dada a composição social da Rússia naquele momento, não é de surpreender que a maior parte dos soldados em ambos os lados fossem camponeses. Enquanto a maioria dos trabalhadores das fábricas apoiavam os Bolcheviques, os camponeses tinham uma atitude profundamente ambígua com relação à guerra civil. Aqueles que podiam ficar de fora, ficavam. (...) O campesinato às vezes apoiava o Exército Vermelho, às vezes o Branco, mas a crueldade em ambos os lados rapidamente os alienava." In: BROWN, Archie. The Rise and Fall of Communism. Vintage Books: 2010, p. 53.
} 
são raríssimos os casos de indivíduos que conseguem aprimorar-se - em sentido dostoievskiano - apenas com base em intuições morais rudimentares. Já vimos que Dostoiévski gostava de idealizar alguns camponeses que tomava por exemplares da "pureza interior" da alma russa, como o mujique Marei e a babá de Púchkin; para ele, estes indivíduos tinham pouca consciência de seu próprio valor e do valor daquilo que representavam - o sentimento fraterno de inspiração cristã -, mas somente o fato de viverem colocando em prática suas intuições rudimentares já bastaria para se construir, na Rússia, uma muralha contra os "erros do Ocidente".

Nada poderia ser mais falso. Não se contém uma revolução tendo como arma apenas as verdades inconscientes de um povo. Nesse sentido, a argumentação pótchviennik, partindo da noção de autoconsciência como base do conhecimento em geral, era razoável com relação ao problema do campesinato russo ao concluir pela urgência de sua educação. Com efeito, na hora H da história russa, o narod achou-se incapaz de avaliar seu próprio lugar histórico - e acabou servindo largamente como massa de manobra a causas cujo sentido último lhe escapava.

O Pótchviennitchestvo, porém, também continha algumas das ideias que, ao longo do desenvolvimento intelectual de Dostoiévski, degenerariam no aspecto mais equivocado de seu pensamento - seu nacionalismo xenófobo. A ênfase pótchviennik na importância da autoconsciência era análoga e complementar à importância dada à imersão do indivíduo em seu universo nacional. Até certo ponto, isto é muito razoável: um homem é feito também à imagem de suas circunstâncias. Mas Dostoiévski parece ter levado este preceito longe demais e, em seu processo de autoconhecimento por meio da incorporação da nacionalidade, fundiu-se a sua terra natal, cegando-se a todo o resto e bloqueando, assim, a própria possibilidade de compreender algo além de suas projeções da Rússia sobre os objetos que analisava. 
Deste modo, seu talento para perceber movimentos psicossociais antes mesmo de estes tomarem formas concretas, tendo como base apenas a psicologia humana, acabou frustrado pelas armadilhas de sua própria psicologia. Mais do que nenhum outro autor, Dostoiévski entendeu a natureza da revolução russa, e se chamá-lo "profeta" já se tornou um cliché, mais difícil é encontrar termo mais apropriado ao seu papel enquanto pensador de seu tempo. E, no entanto, era ele mesmo um produto da mentalidade revolucionária russa.

O mencionado talento perceptivo de Dostoiévski poderia tê-lo feito um antípoda de Herzen, sendo este o mais perfeito expoente da desfiguração de um espírito nobre à força de sua exposição a estímulos contraditórios, à crença de que entre "bem" e "mal" há uma diferença meramente opinativa e de que os desejos humanos existem exclusivamente para obter a saciedade. Dostoiévski estava anos luz à frente de Herzen no que diz respeito à compreensão da natureza humana e de sua relação com tudo o que existe. Mas tem Dostoiévski precisamente a mesma altura que seu opositor revolucionário quando veste a carapuça de ideólogo. Ao fim e ao cabo, tendo chegado muito perto de verdadeiramente prever a essência da história política do século XX, sua ideologia eslavófila o obrigou a enxergar apenas aquilo que todos os socialistas já afirmavam: que a urbanização industrial e a política externa colonialista levariam a Europa ao caos, com guerras impulsionando os proletários às ruas, liquidando o Terceiro Estado e assim por diante. Dostoiévski precisava deste quadro para construir sua utopia eslavófila, e não fez questão de enxergar nada mais além dele. Se tivesse olhado a Rússia com um pouco mais de isenção, ele, que com tanta precisão descreveu os efeitos da cosmovisão utilitário-materialista na alma de seus conterrâneos, teria possivelmente atentado à iminência da eclosão revolucionária em seu país.

Quanto a Herzen, ele foi, nas palavras do próprio Dostoiévski, um gentilhomme russe et citoyen du monde. Seu sentimento pátrio era demasiado imiscuído às demandas de seu 
cosmopolitismo para que lhe coubesse enxergar o real papel da Rússia na história posterior do Ocidente. Ainda assim, suas expectativas políticas acabaram revelando-se mais próximas do que veio de fato a acontecer do que o pan-eslavismo de Dostoiévski. Isto é verdadeiro, ao menos, quanto ao século XX. Já na história mais recente da Rússia, temos presenciado o ressurgimento de ideologias muito próximas à professada pelo autor do Diário de um escritor. São, porém, as ideias pan-eslavistas de Dostoiévski transformadas pela experiência soviética, dando origem a doutrinas como Nacional-bolchevismo e o Eurasianismo, nas quais a ideia de um império encabeçado pela Rússia, destinado a corrigir os erros do Ocidente, alia-se ao militarismo autoritário tipicamente soviético, recorrendo ao mesmo tempo à religião ortodoxa como fator de identidade e união do povo russo.

Tudo isto nos remete, por fim, a "O Grande Inquisidor", o verdadeiro coração da obra dostoievskiana. Uma das leituras mais comuns deste capítulo de Os Irmãos Karamázov o interpreta como uma antevisão do socialismo posto em prática - o que de fato ele é. Porém, fazendo uma leitura mais cerrada do texto, vemos que se trata disto e de mais um pouco.

Diz o Grande Inquisidor a Cristo:

Sabes tu que passarão os séculos e a humanidade proclamará através da sua sabedoria e da sua ciência que o crime não existe, logo, também não existe pecado, existem apenas os famintos? 'Alimenta-os e então cobra virtudes deles!' - eis o que escreverão na bandeira que levantarão contra ti e com a qual teu templo será destruído. No lugar do teu templo será erigido um novo edifício, será erigida uma nova e terrível torre de Babel, e ainda que esta não se conclua, como a anterior, mesmo assim poderias evitar essa torre e reduzir em mil anos os sofrimentos dos homens, pois é a nós que eles virão depois de sofrerem mil anos com sua torre! Eles nos reencontrarão debaixo da terra, nas catacumbas em que nos 
esconderemos (porque novamente seremos objeto de perseguição e suplício), nos encontrarão e nos clamarão: 'Alimentai-nos, pois aqueles que nos prometeram o fogo dos céus não cumpriram a promessa'. E então nós concluiremos a construção de sua torre, pois a concluirá aquele que os alimentar, e só nós os alimentaremos em teu nome e mentiremos que é em teu nome que o fazemos.

Este trecho e outros deixam bastante claro que o futuro referido pelo Grande Inquisidor já se passa em um momento posterior à revolução socialista. Segundo a profecia dostoievskiana, haverá, primeiro, o socialismo (“'Alimenta-os e então cobra virtudes deles!' - eis o que escreverão na bandeira que levantarão contra ti e com a qual teu templo será destruído.”); porém, esta "Torre de Babel" não será concluída e sucumbirá após trazer muito sofrimento à humanidade. Neste momento de desespero, pois "quem prometeu o fogo dos céus não cumpriu a promessa", é que o Grande Inquisidor e os seus virão “concluir a construção da torre", e o farão em nome de Cristo, sob a hipócrita aparência de uma igreja cristã.

Assim, o mais correto não é dizer que sob uma aparente crítica ao catolicismo Dostoiévski descreve o socialismo; esta leitura não é equivocada, porém não é a mais precisa. $\mathrm{O}$ que o romancista faz é lançar mão do livro bíblico do Apocalipse, segundo o qual o advento do Anticristo instaurará uma falsa igreja sobre a terra, para construir uma parábola carregada de significado, na qual o Grande Inquisidor não exatamente encarna - como quer uma leitura mais plana do texto - Stálin ou um ditador declaradamente socialista, mas, mais precisamente, o antipapa que se apossará da Igreja no fim dos tempos, após o fracasso socialista e após expulsar de Roma o verdadeiro pontífice, segundo previsto na escatologia cristã. Ou seja, é impreciso dizer que em "O Grande Inquisidor" Dostoiévski previu a realidade soviética, pois a profecia aí implícita, se alguma há, diz respeito a um futuro ainda por vir. 
Vale enfatizar que o mencionado antipapa seria um continuador do socialismo disfarçado de sacerdote cristão, e por isso é correto ler "O Grande Inquisidor" como uma parábola antissocialista. Contudo, se bem ler literatura é uma tentativa contínua de reinterpretação textual à luz de novos dados da realidade, não podemos deixar escapar esta nuance da obra máxima de Dostoiévski, tão significativa face ao rumo que vem tomando a história mais recente do confronto entre o Ocidente e a Rússia. Dostoiévski não tinha dúvidas de que o chefe impostor da Igreja viria de dentro da própria Roma; talvez haja aí um erro análogo ao que o fez negligenciar a iminência da revolução socialista em seu próprio país. 


\section{BIBLIOGRAFIA}

- $\quad$ ACTON, E. Alexander Herzen and the Role of the Intellectual Revolutionary. Londres, Cambridge UP: 1979.

- $\quad$ BAKHTIN, M. Problemas da Poética de Dostoiévski. Trad. Paulo Bezerra. Forense Universitária, $5^{\mathrm{a}}$ edição: 2010.

- $\quad$ BERLIN, I. Pensadores Russos. São Paulo, Companhia das Letras: 1988.

- $\quad$ BERDYAEV, N. Dostoevsky. Meridian Books: 1968.

The Russian Revolution. University of Michigan Press: 1966

- $\quad$ BILlingtON, J. H. The icon and the axe: an interpretive history of Russian Culture. Nova York, Vintage: 1970.

- $\quad$ BROWN, A. The Rise and Fall of Communism. Vintage Books: 2010.

- $\quad$ CAMUS, A. O Homem Revoltado. Trad. Valerie Rumjanek. Ed. Record: 2008.

- $\quad$ COPLESTON, Frederick. Philosophy in Russia: From Herzen to Lenin and Berdyaev.

Notre Dame, IN: University of Notre Dame Press, 1986.

- $\quad$ CUSTINE, A. de. Letters from Russia. Trad. Anka Muhlstein. NYRB Classics: 2002.

- $\quad$ DOSTOIÉVSKI, F. Crime e Castigo. Trad. Paulo Bezerra. São Paulo, Ed. 34: 2008. Letters of F. M. Dostoevsky to his family and friends. Trad. Ethan C.

Mayne. University Press of the Pacific: September 2003. Memórias do Subsolo. Trad. Boris Schnaiderman. São Paulo, Ed. 34: 2008.

$-$ O Adolescente. Trad. Diego Rodrigues. São Paulo, Companhia das Letras: 2010. O Crocodilo e Notas de Inverno Sobre Impressões de Verão. Trad. Boris Schnaiderman. São Paulo, Ed. 34: 2008.

$-$ Os Demônios. Trad. Paulo Bezerra. São Paulo, Ed. 34: 2004.

$-$ O Idiota. Trad. Paulo Bezerra. São Paulo, Ed. 34.

$-$ Os Irmãos Karamázov. Trad. Paulo Bezerra. São Paulo, Ed. 34:

2009. 
Pólnoie sobrânie sotchiniêni v trídtsati tomákh. Leningrado: Naúka, 1972-1990. Recordações da Casa dos Mortos. Trad. José Geraldo Vieira. Coleção Jabuti. Ed. Saraiva: 1958. $-$ A Writer's Diary, vol. 1 e 2. Trad. Kenneth Lantz. Northwestern University Press: July 1997.

- DOWLER, Wayne. Dostoevsky, Grigor'ev, and Native-Soil Conservatism. Toronto, Buffalo and London: University of Toronto Press, 1982.

- $\quad$ FONVIZINE, D. Lettres de France (1777-1778). Paris, CNRS Éditions : 1995.

- $\quad$ FRANK, J. As Sementes da Revolta - 1821 a 1849. Ttrad. Vera Pereira. São Paulo, Edusp: 1999. $-$ Between Religion and Rationality. Essays in Russian Literature and Culture. Princeton UP: 2010.

- _ Os Anos Milagrosos - 1865-1871. Trad. Geraldo Gerson Souza. São Paulo, Edusp: 2003. Os Anos de Provação - 1850 a 1859. Trad. Vera Pereira. São Paulo, Edusp: 1999. $-$ Os Efeitos da Libertação - 1860-1865. Trad. Geraldo Gerson Souza. São Paulo, Edusp: 2002. $-$ O Manto do Profeta - 1871 a 1881. Trad. Geraldo Gerson Souza. São Paulo, Edusp: 2002. Pelo Prisma Russo. Ensaios sobre literatura e cultura. Trad. Paula Cox Rolim e Francisco Achcar. São Paulo, Edusp: 1992.

- GAUVAIN, J (Trad.). Relatos de um peregrino russo. Autor anônimo, 1865. Ed. Paulus: 1985 .

- GEORGE, PATTINSON \& THOMPSON (Eds.). Dostoevsky and the Christian Tradition. Cambridge University Press: 2001.

- $\quad$ GIRARD, R. Dostoiévski: do duplo à unidade. São Paulo, É Realizações: 2011.

- GOMIDE, B. (Org.) Antologia do Pensamento Crítico Russo (1802-1901). São Paulo, Ed. 34: 2013. 
- HERZEN, A. From the Other Shore \& The Russian People and Socialism. Intro. by Isaiah Berlin. Oxford UP, 1979.

$-$ Letters from France and Italy 1847-1852. Trans. Judith E. Zimmerman. Pitt Series in Russian and East European Studies. University of Pittsburgh Press: November 1995. $-$ My Past and Thoughts: The Memoirs of Alexander Herzen. 4 Vols. Tr. by Constance Garnett, revised by Humphrey Higgens. London: Chatto and Windus, 1968.

$-$ Selected Philosophical Works. Foreign Languages Publishing House, Moscou: 1956.

$-$ Sobrânie sotchiniêni v trídtsati tomákh. Moscou: Izdatel'stvo Akademii nauk SSSR, 1954-1965.

- $\quad$ IVANITS, L. J. Dostoevsky and the Russian People. Cambridge University Press: 2008.

- $\quad$ LEATHERBARROW, W. (Ed.) The Cambridge Companion to Dostoevskii. Cambridge UP: 2004.

- LEATHERBARROW, W. \& OFFORD, D. (Eds.). A History of Russian Thought. Cambridge UP: 2010.

- $\quad$ KARAMZIN, N. Letters of a Russian Traveller. Oxford, Voltaire Foundation: 2003.

- Memoir on Ancient and Modern Russia. Translation and study by Richard Pipes. Michigan UP: 2005.

- KHOMIAKOV, A. The Church is One. With an introduction by Bishop Gregory (Grabbe). The St. John of Kronstadt Press.

- $\quad$ KUEHNELT-LEDDIHN, E. von. Leftism Revisited: From de Sade and Marx to Hitler and Pol Pot. Regnery Pub: 1991.

- OFFORD, D. Journeys to a Graveyard. Perceptions of Europe in Classical Russian Travel Writing. Springer: 2005.

- $\quad$ PIPES, R. Communism: A History of the Intellectual Movement. Phoenix: 2003.

- ___ Russia under the Old Regime. Penguin History, second edition: 1997.

- ___ Russian Conservatism and Its Critics: A Study in Political Culture. Yale UP: 2006.

- PUSHKIN, A. S. “A Journey to Arzrum”. In: Tales of Belkin and Other Prose Writings. Tr. Ronald Wilks. Penguin Books: 1998. 
- $\quad$ RADISHCHEV, A. N. A Journey from St. Petersburg to Moscow. Tr.by Leo Wiener and ed. by Roderick Page Thaler. Cambridge, MA: Harvard University Press, 1958.

- SANDOZ, E. Political Apocalypse: a study of Dostoevsky's Grand Inquisitor: ISI Books: June 2000.

- $\quad$ SOLOVYEV, Vladimir. Russia and the Universal Church. Traduzido do original francês por Herbert Rees. Londres, The Centenary Press: MCMXLVIII.

- $\quad$ TCHERNICHÉVSKI, N. What is to be done? Cornell UP: 1989.

- VENTURI, F. Roots of Revolution. A history of the populist and socialist movements in nineteenth century Russia. The Universal Library - Grosset \& Dunlap, New York: 1960.

- $\quad$ VOEGELIN, E. The Collected Works of Eric Voegelin - Volume 5. Columbia, University of Missouri Press: 2000.

- WALICKI, A. The Slavophile Controversy. History of a Conservative Utopia in Nineteenth-Century Russian Thought. Oxford, Clarendon Press: 1975.

- $\quad$ WARE, T. The Orthodox Church. Penguin Books, $2^{\text {nd }}$ edition: 1997.

Principais Artigos:

- $\quad$ CROSS, A. G. "Russian Perceptions of England, and Russian National Awareness at the End of the Eighteenth and the Beginning of the Nineteenth Centuries". The Slavonic and East European Review, Vol. 61, No. 1, Kiev Congress Papers (Jan.,1983), pp. 89-106.

- $\quad$ FRANK, J. "Dostoevsky: The Encounter with Europe”. Russian Review, Vol. 22, No. 3 (Jul., 1963), pp. 237-252.

- $\quad$ GROSS, I. G. "The Tangled Tradition: Custine, Herberstein, Karamzin, and the Critique of Russia”. Slavic Review, Vol. 50, No. 4 (Winter, 1991), pp. 989-998

- $\quad$ KLEESPIES, I. "Caught at the Border: Travel, Nomadism, and Russian National Identity in Karamzin's Letters of a Russian Traveler and Dostoevsky's Winter Notes on Summer Impressions". The Slavic and East European Journal, Vol. 50, No. 2 (Summer, 2006), pp. 231251.

- $\quad$ LAYTON, S. "The Divisive Modern Russian Tourist Abroad: Representations of Self and Other in the Early Reform Era". Slavic Review, Vol. 68, No. 4 (Winter, 2009), pp. 848-871. 
- $\quad$ OFFORD, D. "Beware the Garden of Earthly Delights: Fonvizin and Dostoevskii on Life in France". The Slavonic and East European Review, Vol. 78, No. 4 (Oct., 2000), pp. 625-642.

- $\quad$ OFFORD, D. "In Search of Victorian Virtues: the Russian Liberals' View of Britain in the 1850s." Quinquereme, Vol. 8, No. 2 (July 1985), pp. 173-187.

- $\quad$ PIPES, R. "The Historical Evolution of the Russian Intelligentsia”. Daedalus, Vol. 89, No. 3, The Russian Intelligentsia (Summer, 1960), pp. 487-502.

"Russian Conservatism in the Second Half of the Nineteenth". Slavic Review, Vol. 30, No. 1 (Mar., 1971), pp. 121-128

- SANDOZ, E. "Philosophical Anthropology and Dostoevsky's Legend of the Grand Inquisitor". The Review of Politics, Vol. 26, No. 3 (Jul., 1964), pp. 353-377.

- _Philosophical dimensions of Dostoevsky's politics". The Journal of Politics, Vol. 40, No. 3 (Aug., 1978), pp. 648-674.

- WALSH, D. "Dostoevsky's Discovery of the Christian Foundation of Politics". Religion \& Literature, Vol. 19, No. 2 (Summer, 1987), pp. 49-72. 